UNIVERSIDADE DE SÃO PAULO

FACULDADE DE FILOSOFIA, LETRAS E CIÊNCIAS HUMANAS

DEPARTAMENTO DE LETRAS CLÁSSICAS E VERNÁCULAS

PROGRAMA DE PÓS-GRADUAÇÃO EM LITERATURA PORTUGUESA

\title{
O JESUS DE SARAMAGO \\ E A LITERATURA QUE REVISITA CRISTO
}

Ronaldo Ventura Souza

Dissertação apresentada ao Programa de Pós-Graduação em Literatura Portuguesa, do Departamento de Letras Clássicas e Vernáculas da Faculdade de Filosofia, Letras e Ciências Humanas da Universidade de São Paulo, para obtenção do título de Mestre em Letras.

Orientador: Prof. Dr. José Horácio de Almeida Nascimento Costa 
à minha família 


\section{AGRADECIMENTOS}

À meus pais, Marciano e Maria Eunice e meus irmãos, Robson, Rosimeire, Rosilene, Sara e Davi, pelo apoio que sempre me deram desde sempre.

À Maria de Lourdes P. Cardoso, minha professora no ensino básico e fundamental, a seu esposo Erich Cardoso e seus filhos Erika, Erike e Luciano por todo apoio que me deram no início de minha caminhada.

A meus amigos Nivaldo, Francisco e Henrique pelas noites de Rei das Batidas e bilhar em que conversamos sobre diversos assuntos, entre eles, quem diria, literatura, o que em alguns momentos me ajudou a refletir sobre o meu trabalho.

A meus amigos Carlos, Renata e Idelvânia por todos esses anos de convivência desde a graduação.

A Nivaldo, Henrique, César, Priscila, Camila, Liliam, Aristóteles, Everton e Rosa, que compartilharam moradia comigo no CRUSP, pelo bom ambiente em que pude desenvolver esta dissertação.

Ao meu orientador pelo apoio e pela confiança.

Aos meus amigos Aristóteles e Danilo pela minuciosa revisão do texto.

À FAPESP pela bolsa de Iniciação Científica, cujo resultado abriu caminho para o tema da presente dissertação.

Ao CNPq pela bolsa de mestrado que foi de suma importância para o desenvolvimento da presente dissertação. 


\title{
RESUMO
}

A presente dissertação tem como objetivo analisar o processo de elaboração da personagem Jesus de O Evangelho Segundo Jesus Cristo, de José Saramago, a partir da consideração do cânone literário que tem como propósito reler a história estabelecida pelos evangelhos escritos nos primórdios do Cristianismo. Isto é feito primeiro pela seleção de alguns exemplos do referido cânone e depois pela análise da personagem saramaguiana procurando mostrar como ela se relaciona com essas outras versões de Cristo.

\begin{abstract}
This dissertation has as objective analyzes the process of the elaboration character Jesus of José Saramago's O Evangelho Segundo Jesus Cristo, starting from the consideration of the literary canon that has as purpose to read again the established history for the Gospel written in the origins of the Christianity. That is done first by the selection of some examples of the referred canon and later for the analysis of the Saramago's character trying to show like it relations with those other versions of Christ.
\end{abstract}

\section{PALAVRAS-CHAVE/KEY WORDS}

Romance, evangelho, cânone, Jesus, personagem

Novel, gospel, canon, Jesus, character 


\section{ÍNDICE}

I. INTRODUÇÃO

1. Novas Versões de Cristo 7

2. Uma história arquiconhecida 13

II. A LITERATURA QUE REVISITA CRISTO 20

1. A Biblioteca Virtual 20

2. O Jesus dos evangelhos 22

3. Jesus diante da Inquisição: “O Grande Inquisidor”, de Dostoiévski 27

4. Jesus segundo Renan: A Vida de Jesus 31

5. Jesus segundo Judas Iscariotes: Memórias de Judas, F. P. de la Gattinna 34

6. $\quad$ Os Cristos de Eça de Queiroz 38

6.1. Jesus segundo um guarda do Templo: "Morte de Jesus" 38

6.2. Teodorico e o Diabo: A Relíquia 41

6.3. Jesus segundo S. Teodorico: A Relíquia 43

6.4. Cristo, a esperança dos pobres: "O Suave Milagre” 48

7. Jesus e o Padre Eterno em A Velhice do Padre Eterno: Guerra Junqueiro 51

8. O menino Jesus: Fernando Pessoa 56

9. Jesus nas ruas de Lisboa: Raul Brandão e Teixeira de Pascoaes 59

10. O Cristo que não quer ser Cristo: A Última Tentação de Cristo, Nikos 63 Kazantzakis

11. Deus, a maldição da humanidade: Pär Lagerkvist 69

11.1. Os Atos dos Apóstolos ao avesso: Barrabás 69

11.2. Cristo, um desgraçado como nós: Muerte de Ahaverus 77

12. Judas Iscariotes: de um reles traidor a filho de Deus 80

III. O JESUS DE SARAMAGO 83

1. A natividade 83

2. O menino Jesus 100

3. Jesus em busca de autoconhecimento 106

4. Jesus e Pastor (Diabo) 117

5. Maria de Magdala e Jesus $\quad 122$ 
6. Os últimos anos da vida de Jesus 130

IV. CONCLUSÃO 146

V. BIBLIOGRAFIA 150

1. Bibliografia ativa 150

2. Bibliografia passiva 153 


\title{
I. INTRODUÇÃO
}

\author{
E se Deus é canhoto \\ e criou com a mão esquerda? \\ Isso explica, talvez, as coisas deste mundo. \\ ("Hipótese”, Carlos Drummond de Andrade)
}

\section{Novas Versões de Cristo}

Até o século XVIII era inimaginável que o conteúdo dos evangelhos canônicos pudesse ser contestado. Ao contrário de outros historiadores da Antigüidade, os textos sobre a vida de Jesus traziam o selo da aprovação divina, possuíam a garantia celeste de que eram verdadeiros. "De fato, para muitos, os evangelistas eram porta-vozes de Deus; seus evangelhos eram um ditado de Deus” (VERMES, 1996, p. 26). Assim, não havia quem tivesse a coragem para questionar o conteúdo desses textos sagrados.

No entanto, a partir do Iluminismo a autoridade absoluta dos textos bíblicos começa a ruir. O selo de aprovação divina já não se mostra suficiente para atestar a veracidade dos evangelhos. E vistos sem a aura celeste, eles ficam expostos a diversas indagações sobre as lacunas e enigmas neles encontrados, sem contar, é claro, com as contradições existentes entre eles. A respeito de Cristo são quatro os relatos existentes no Novo Testamento: Mateus, Marcos, Lucas e João que, segundo David Flusser, são as únicas fontes cristãs importantes no que diz respeito à vida e obra de Jesus. Todavia, cada uma dessas quatro narrativas apresenta Cristo à sua maneira. Assim, podemos nos perguntar qual delas está correta. Ou melhor, o que há de verdadeiro em tais relatos sobre a vida do messias cristão? São perguntas difíceis e que parecem não ter uma resposta precisa. O que não falta, porém, são escritores que se debrucem sobre a História mais importante da cultura cristã ocidental com o intuito de relê-la com outros olhos que não os da religião. O que estes autores propõem é uma leitura heterodoxa do mito bíblico seja por meio de uma tentativa geralmente frustrada de recuperá-lo historicamente $^{1}$, visto a possibilidade de múltiplas interpretações que estes textos oferecem, seja por meio da literatura, através de romances, poemas e contos, em que se oferece uma

\footnotetext{
${ }^{1}$ Crossan, em seu prólogo a O Jesus Histórico, publicado em 1991, alude às dificuldades de se debruçar sobre o tema do Jesus histórico. Há uma variedade de interpretações feitas sobre a figura de Jesus, que despertam a desconfiança sobre esse tipo de estudo no mundo acadêmico. "Essa impressionante diversidade, no entanto, é considerada um motivo de vergonha no mundo acadêmico. É impossível evitar a desconfiança de que a pesquisa do Jesus histórico é um campo em que se pode fazer teologia e chamá-la de história, ou fazer autobiografia e
} 
nova versão da personagem Jesus, distinta da tradicionalmente aceita pelas instituições cristãs.

No século XIX, a história divina contada nos textos bíblicos começa a receber interpretações heterodoxas dadas pela História, Filosofia e Literatura. Em A Essência do Cristianismo, Ludwig Feuerbach discute a religião cristã a partir de um ponto de vista bastante peculiar: Deus se caracteriza como fruto da imaginação humana, uma resposta aos seus anseios, uma forma do homem superar suas contrariedades, seus limites. Para Feuerbach, “a oposição do divino e do humano é inteiramente ilusória e, por conseqüência, que também o objeto e o conteúdo da religião são inteiramente humanos” (1994, p. 24). No entanto o homem ignora o fato de Deus ser o resultado de sua própria essência, da consciência que ele tem de si, e é essa ignorância que cria a especificidade da religião, que nada mais é que fruto do próprio egoísmo humano. Podemos pensar, então, que Deus não existe a não ser como um ideal e nesse sentido, a ressurreição de Cristo é, segundo o autor, uma realização do desejo do homem de uma certeza imediata de que sobreviverá após a morte.

A mudança de postura, observada acima, em relação ao modo de ver o divino é patente nas releituras heterodoxas sobre o mito inicial do Cristianismo. No poema em cinco partes "Le Christ aux Oliviers”, de Gérard de Nerval, é anunciado, pela boca do próprio Cristo no calvário, a não existência de Deus: “Et se prit à crier : “Non, Dieu n’existe pas!” (NERVAL, 1864, p. 76). E o Jesus do poema Sueño, de Jean Paul Ritcher, citado por Octavio Paz, em "Los hijos del limo”, depois de percorrer todos os mundos anuncia à humanidade que não encontrou Deus algum: "Los niños muertos se acercan a Cristo y le preguntan: Jesús, no tenemos padre? Y él responde: todos somos huérfanos” (PAZ, 1993, p. 373-4). E, neste caso, Cristo se equipara aos homens, pois comunga com eles a mesma orfandade.

Em vista disso, o objetivo do presente trabalho é investigar o modo como Jesus, enquanto personagem mítica central da cultura cristã, é reelaborado em diversos textos, seja pela tentativa de dar uma versão histórica de quem pode ter sido o homem chamado Jesus e de como ele se tornou a figura mais ilustre da cultura cristã, seja pelo esforço de produzir uma versão ficcional dessa história arquiconhecida na cultura ocidental. E, a partir disso, pretendemos verificar como José Saramago dialoga com esses escritos na construção da personagem principal de O Evangelho Segundo Jesus Cristo, comparando os traços que a compõem com aqueles que caracterizam essas outras versões de Cristo. Pretendemos, assim, 
situar a personagem central desse romance no contexto de um cânone religioso não ortodoxo, em que a figura de Cristo aparece despida, total ou parcialmente, de seu manto sagrado.

É evidente que os evangelhos bíblicos são a principal fonte para essas histórias de Cristo. Em um momento do primeiro século da era cristã, alguém decidiu que era preciso reunir em um texto todos os relatos sobre a vida do mestre de Nazaré. E assim surgiu o evangelho de Marcos, que, segundo alguns críticos ${ }^{2}$, foi o primeiro evangelho a ser escrito por cerca de 70 d.C. A ele se seguiram Lucas e Mateus, num período entre 80 e 90 . O evangelho de João foi escrito próximo do ano 100 d.C. (Cf. GABEL \& WHEELER, 1993, pp. 170-1).

O percurso do Jesus bíblico é sempre um dado a priori nessas narrativas ${ }^{3}$. Para os evangelistas, sua presença na terra está intimamente ligada ao cumprimento das profecias do Antigo Testamento. Ele veio ao mundo como o filho de Deus e tudo que com ele ocorra deve se alinhar nessa concepção. Assim, o seu nascimento, narrado por Mateus e Lucas, deve ser apropriado ao de uma criança divina. A fase de infância e adolescência não aparece nos evangelhos canônicos talvez porque não tenha a menor importância para o que pretendiam os seus autores, cujo objetivo principal era apresentar a seus leitores a carreira de Jesus no cumprimento das promessas divinas ${ }^{4}$. Desse modo, os evangelhos canônicos tratam dos feitos

\footnotetext{
${ }^{2}$ Para David Flusser, Lucas foi escrito antes de Marcos que, por sua vez, influenciou a escrita do Evangelho de Mateus (Cf. FLUSSER, 2002, p. 4).

${ }^{3}$ Em trabalho de Iniciação Científica, intitulado Jesus: o de Saramago e o dos Evangelhos, que desenvolvemos com o auxílio da FAPESP, sob orientação do Prof. Dr. Horácio Costa, em 2003, comentamos a semelhança da narrativa bíblica em relação à epopéia clássica, tal como definida por Lukács em A Teoria do Romance: "O modo como se constitui o herói dos evangelhos se assemelha muito ao da epopéia clássica. Segundo Lukács, neste gênero da antiguidade o herói representa o destino de uma comunidade, o que faz com que ele nunca seja a caráter um indivíduo, pois não é um ser isolado desse cosmos, mas faz parte de um todo perfeito, de modo que para a epopéia não interessa a interioridade do sujeito, pois o todo orgânico e perfeito que forma o gênero impossibilita que uma de suas partes possa isolar-se em si mesma. Parece-nos que Jesus dos evangelhos, embora não seja exatamente uma personagem épica, assemelha-se a este tipo de herói mítico, pois também possui uma estreita relação com o destino de uma comunidade, que irá se formar logo após a sua morte e ressurreição: a comunidade cristã. Assim, do mesmo modo que o herói grego, esta personagem tem o seu destino já determinado por Deus e a luta de sua vida é algo a priori resolvido, de modo que ela já é em si plena de essência, não necessitando buscá-la em sua luta com o cotidiano”.

${ }^{4}$ No mesmo trabalho citado acima, o assunto foi abordado da seguinte forma: "Parece possível pensar que não houvesse o interesse dos evangelistas bíblicos de relatar um período parecido com o que ocorre no romance, em que houvesse um amadurecimento da personagem principal, mesmo porque esta já tinha plena consciência de seu destino diante dos homens e de Deus. Semelhante narrativa só seria justificável se necessária para reforçar a natureza de taumaturgo e exorcista da fase final da vida da personagem. O Jesus bíblico é sempre um dado a priori, uma personagem já formada, com o destino determinado antes mesmo de principiar a história. Desse modo, parece-nos que uma narrativa que não tivesse como objetivo mostrar a parte da história de Jesus ligada a seu ministério terreno e a demonstrar que ele é o filho de Deus seria pouco interessante, dadas as necessidades que se impunham aos evangelistas que era a de confirmar a fé cristã. Assim não parece necessário mostrar o
} 
e ditos de Jesus e do que é considerado o principal evento do cristianismo: a morte e ressurreição de Cristo.

Os quatro evangelhos canônicos, embora tenham em comum o objetivo de narrar a história de Jesus, diferem entre si sob vários aspectos. Eles foram escritos para atender necessidades de comunidades distintas em diferentes momentos do período inicial do cristianismo. Segundo Kermode, essas diferenças emergem, por um lado, da variedade do material tradicional disponível e das necessidades de cada uma das comunidades para qual os evangelistas escreviam. Por outro lado, cada um desses escritores "viu o material básico de modo diferente, trabalhou-o de modo diferente e imprimiu nele um método literário e um talento específicos” (1997b, p. 417). O certo é que Marcos, Lucas e Mateus

têm muito em comum no tocante a apresentação da história e ao seu vínculo mútuo como textos. Por isso eles são denominados evangelhos 'sinóticos' (os que podem ser vistos conjuntamente) e costumam ser estudados em grupo. O evangelho de João é obviamente uma classe em si mesmo (GABEL \& WHEELER, 1993, p. 168).

Tal variedade de abordagens em relação à mesma história nos leva a uma tradição de múltiplos relatos sobre a vida de Cristo, que não estão restritos apenas a esses evangelhos, pois também existem os chamados apócrifos. Em seu ensaio “The Art of Rewriting the Gospel”, Fokkema observa que o fato de haver diversos relatos, muitas vezes contraditórios entre si, sobre a vida de Jesus, faz-nos deduzir que nenhum deles pode ser completamente verídico. Tal motivo se apresenta como um convite para que vários escritores se propusessem, a partir do Romantismo, a reescrever essas histórias de Cristo:

There is not one official text relating his life, but there are four different gospels, each throwing a particular light on what it considers historical truth and leaving other things in the dark. And these four gospels were selected by the Council of Trento ${ }^{5}$ out of an even greater number accounts. If truth can be conveyed in at least four different ways, it means that none of these recordings is completely satisfactory (FOKKEMA, 1999, p. 395).

período da passagem da adolescência para fase adulta em que se estaria formando um indivíduo chamado Jesus, pois a preocupação com a formação do indivíduo é uma preocupação inerente à forma romanesca e não ao gênero ao qual pertencem os evangelhos bíblicos”.

5 Segundo Kermode, o encerramento do cânone do Novo Testamento se deu em 367 d.C., “quando Atanásio catalogou os 27 livros como livros canônicos. Ele usou de fato essa palavra e forneceu também uma lista de livros rejeitados, que chamou de apócrifos. Dúvidas persistiram, e pode haver discussão quanto a se o cânone pode ser considerado encerrado; mas nada foi acrescentado depois, nem tampouco extraído dele; e é difícil como o Evangelho de Tomé, descoberto nesse século, se acrescentado ao cânone, poderia participar da autoridade adquirida pelos outros ao longo dos anos” (KERMODE, 1997, p. 646). A primeira imposição da lista elaborada por Atanásio ocorreu no Concílio de Calcedonia em 451 d.C. No Concílio de Trento, que foi realizado entre 1545-1563, essa formação canônica do Novo Testamento que vigora até hoje foi confirmada. 
Desse modo, preencher as lacunas e responder as contradições dos textos bíblicos é talvez o motivo propulsor de vários escritores que nos últimos duzentos anos lançaram um novo olhar sobre a história mais conhecida do Ocidente.

Dentro dessa linha de releituras do mito cristão podemos citar Ernest Renan. Esse escritor francês procura apresentar, em seu livro Vida de Jesus, uma nova versão da história narrada nos evangelhos, em que vê Jesus como um judeu com idéias muito revolucionárias para a sua época. O esforço de Renan consiste em tentar dar uma explicação racional ao que é contado nesses textos bíblicos. Para isso, ele supõe como poderia ter vivido o homem Jesus no mundo ao qual pertenceu, tentando separar o que é lenda do que de fato pode ter acontecido:

Jesus nasceu em Nazareth, pequena cidade da Galiléia, desconhecida até então. Toda a sua vida foi designado de "Nazareno" e só por um esforço que se não compreende é que poderia, segundo a lenda, dá-lo como nascido em Belém (RENAN, 1926, pp. 16-7).

O fato de o autor considerar que Jesus, por ter sido chamado o nazareno durante toda a sua vida, e só poder ter nascido em Nazaré, e não em Belém como afirma a tradição cristã através dos evangelhos, pode ser caracterizado como uma tentativa de dar à história do filho de Maria um caráter mais racional. Para Renan, Jesus era como qualquer judeu de sua época, o que o destaca dos outros é o seu modo de pensar a religião de seu povo, lançando sobre ela um novo olhar, que acabou por trazer ao mundo o cristianismo. Caracterizar Jesus como uma personagem histórica será um tema recorrente durante o século XX, Jesus (1968), de David Flusser, Jesus, o judeu, de Geza Vermes e O Jesus Histórico (1991), de John Dominic Crossan, citados durante esse trabalho, são exemplos disso. Para Renan, Jesus é um homem fora de série e seu "Deus não lhe fala como quem está fora dele; Deus está nele; ele sente-se com Deus e tira do seu coração que diz de seu Pai” (1926, p. 61). Tal imagem de Deus pode ser relacionada com o tema de A essência do Cristianismo de Feuerbach, em que o divino é um reflexo da própria essência humana.

Se Renan tentou oferecer uma explicação histórica para o que é contado nos evangelhos, outros escritores buscaram elaborar uma versão ficcional para esses textos sagrados. Podemos citar aqui obras como Memórias de Judas (1866), de Ferdinando Petrucelli della Gattina, em que Jesus aparece completamente humanizado. Nesse romance, 
por exemplo, os milagres não passam de mero fruto da imaginação popular e o filho de Maria aparece como um hábil realizador de truques, tal como pode ser notado na releitura do episódio da cura de um cego encontrado no Evangelho de $\operatorname{Marcos}^{6}$. Depois da cura, de modo distinto dos evangelhos que apresentam apenas um ponto de vista, os presentes se dividem em dois grupos, um dos que acreditam ser mesmo um milagre e outro dos que desconfiam, com alguma razão, de que tudo não passa de charlatanismo:

Este curativo foi operado pelo rabino de modo tão pronto, tão rápido, tão hábil, que seus discípulos e plebe gritavam que era milagre! Mas os fariseus, os escribas e as outras pessoas instruídas ridicularizavam como sendo alicantina de charlatão. Os mais conscienciosos dentre eles chamavam-no de louco e diabo e interrogavam o cego que eles suspeitavam ser algum dos discípulos ou comparsa (GATTINA, 1946, p. 262).

Outro romance do século XIX, A relíquia (1887), de Eça de Queiroz, pode ser citado também como exemplo dessa espécie de cânone literário a que estamos nos referindo nesse trabalho. Nessa narrativa, o milagre da ressurreição de Cristo não passa de uma mera armação produzida por alguns de seus amigos, que roubam o seu corpo do túmulo e, considerando que ele ainda não havia morrido de fato, tentam reanimá-lo sem nenhum sucesso, pois Jesus acaba morrendo durante a tentativa:

Estendemos Jesus na esteira. Demos-lhe de beber os cordiais, chamamo-lo, esperamos, oramos... Mas ai! sentíamos, sob as nossas mãos, arrefecer-lhe o corpo!... Um instante abriu lentamente os olhos, uma palavra saiu-lhe dos lábios. Era vaga, não a compreendemos... Parecia que evocava seu pai, e que se queixava de um abandono... Depois estremeceu: um pouco de sangue apareceu-lhe no canto da boca. E, com a cabeça sobre o peito de Nicodemo, o Rabi ficou morto! (EÇA DE QUEIROZ, 1997, p. 159).

É patente, nos dois romances acima, ambos do século XIX, a tentativa de dar um caráter racional à narrativa evangélica, rebaixando a personagem a padrões completamente humanos. Desse modo, no primeiro romance, Jesus é caracterizado como uma "espécie de louco" que vive dizendo ser o filho de Deus, embora não seja mais que homem astuto e singular; no segundo romance, a ressurreição, que é considerada por muitos como fundamental para a crença cristã, caracteriza-se como uma farsa, o que também acontece no romance de Gattina, onde o filho de Maria morre por doença, em Roma, ao lado de Judas

\footnotetext{
6 "E chegaram a Betsaida. Trouxeram-lhe então um cego, rogando que ele o tocasse. Tomando o cego pela mão, levou para fora do povoado e, cuspindo-lhe nos olhos e impondo-lhe as mãos, perguntou-lhe: 'Percebes alguma coisa?' E ele, começando a ver, disse: 'Vejo as pessoas como se fossem árvores andando'. Em seguida ele colocou novamente as mãos sobre os olhos do cego, que viu distintamente e ficou restabelecido e podia ver tudo
} 
Iscariotes, três anos depois da crucificação. O conteúdo dos dois romances é, do ponto de vista religioso, uma grande heresia, uma vez que a figura de Cristo é rebaixada ao totalmente humano e é até mesmo ridicularizada, já que ele mais se parece com um fanático religioso tanto no sonho de Teodorico, em A Relíquia, como no romance de Gattina.

Em outras obras do século XX, a releitura da história de Cristo não resulta numa completa humanização da personagem central da narrativa como ocorre nas obras mencionadas acima. Tal como nos evangelhos, Jesus é apresentado com as características que fazem dele um deus. No entanto, enfatiza-se seu lado humano que entra em conflito com o divino, fruto de suas características especiais. É o caso, por exemplo, de A Última Tentação de Cristo (1951), de Nikos Kazantzakis, em que a “última tentação” consiste em um sonho que Jesus tem na cruz pouco antes de morrer, no qual vive como um homem comum ao abandonar seu papel como o messias que deveria ser sacrificado pela humanidade. Há, nesse romance, uma constante tensão entre o desejo que Jesus tem de ser como qualquer homem e a sua obrigação de representar o papel de Filho de Deus, cujo destino é ser crucificado: o maior desejo de Cristo é casar com Maria Madalena e constituir uma família. Por conta disso, durante todo o romance, Jesus luta para vencer os seus desejos sexuais:

Ele sentia que ainda possuía muito de barro dentro de si, muito do ser humano. Era ainda vulnerável à raiva, ao medo, ao ciúme; quando pensava em Madalena seus olhos ficavam turvos, e mesmo na noite anterior, ao contemplar Maria, a irmã de Lázaro... (KAZANTZAKIS, 1988, p. 304).

Em Muerte de Ahasverus (1960), de Pär Lagerkvist, que explora o mito do judeu errante, apresenta-se uma personagem que odeia Jesus, por ter sido amaldiçoado por ele a viver vagando pelo mundo durante séculos. No entanto, ao termo da narrativa, Ahasverus reconhece em Cristo, um irmão na desgraça, o companheiro de infortúnios da humanidade, pois ele também foi suspenso na cruz, assim como muitos outros, e se tornou símbolo do sofrimento de todos esses infelizes. A figura má, o responsável pela desgraça humana, no final das contas, é Deus, pois é ele quem exige o sacrifício do homem, começando pelo martírio do próprio filho e estendendo essa maldição a toda humanidade.

Essas e outras releituras da história de Jesus, que trataremos nesse trabalho, integram um cânone literário não ortodoxo do qual faz parte O Evangelho Segundo Jesus Cristo, objeto 
de análise principal do presente estudo. 


\section{Uma história arquiconhecida}

Ao princípio da narrativa de O Evangelho Segundo Jesus Cristo, a personagem principal, originária de uma história arquiconhecida na cultura ocidental, desconhece completamente sua ascendência divina. O fato de ser filho de Deus é algo que Jesus só irá descobrir mais tarde, quando seu pai divino requisitar que ele cumpra o destino para o qual foi criado. Assim, o único pai que o Cristo saramaguiano reconhece é José, cujo destino é ser crucificado, por engano, pelos romanos como um rebelde. E é a partir desse fato que Jesus entra de vez no novo evangelho escrito por Saramago. E ao contrário do messias encontrado nos evangelhos bíblicos, a figura central desse romance de Saramago está sempre envolto em dúvidas, incertezas, remorsos e outros sentimentos tais que lhe conferem sua humanidade. Ele sente dores como um homem comum e como tal é capaz de amar uma mulher. E ao saber que é filho de Deus, recusa-se reconhecer seu caráter divino e se coloca ao lado dos homens: "Sou um homem, vivo, como e durmo como um homem e como um homem viverei” (SARAMAGO, 2001, p. 365). Nas palavras de Leyla Perrone-Moisés, o Jesus de Saramago “não é totalmente divino, nem totalmente humano: é uma personagem de ficção” (1999, p. 240).

Essa é a personagem, cujo processo de criação nos propomos estudar aqui. Como já vimos acima, a releitura heterodoxa do mito cristão é um fenômeno bastante recorrente desde o século XIX. E é dentro dessa espécie de cânone literário formado desde então, que se insere o Jesus saramaguiano. E tal como a maioria dessas novas versões do mito central do Cristianismo criadas nos dois últimos séculos, a essência da história de Cristo contada por Saramago "is a critique of revealed truth, and in particular rejection of original sin" (FOKKEMA, 1999, p. 400).

O dispositivo literário utilizado por Saramago, como também por outros escritores, entre os quais podemos citar Eça de Queiroz, que relê o episódio da paixão de Cristo através do sonho de Teodorico no terceiro capítulo de A Relíquia, ou Kazantzakis, que apresenta a história de Jesus sob outra perspectiva, em A Ùltima Tentação de Cristo, é a paródia. Segundo Linda Hutcheon, a paródia se caracteriza como “uma repetição com distância crítica, que marca a diferença em vez da semelhança, de modo que 'a inversão irônica' é uma característica de toda paródia” (HUTCHEON, 1985, p. 18). Para exemplificar tal 
característica do romance de Saramago, vejamos uma comparação do episódio da mulher adúltera presente no quarto evangelho e recontada, em outros termos, pelo romancista. O referido episódio se encontra no capítulo oito do Evangelho Segundo João. Flagrada em adultério, a mulher é levada pelos fariseus até Jesus, para que este se pronunciasse a respeito da sentença destinada a ela de acordo com a Lei mosaica. Eis como o evangelista descreve a cena:

\begin{abstract}
Antes do nascer do sol, já se achava outra vez no Templo. Todo o povo vinha a ele e, sentando-se, ensinava. Os escribas e os fariseus trazem, então, uma mulher surpreendida em adultério e, colocando-a no meio, dizem: "Mestre, esta mulher foi surpreendida em flagrante delito de adultério. Na Lei, Moisés nos ordena a apedrejar tais mulheres. Tu, pois, que dizes?” Eles assim diziam para pô-lo a prova, a fim de terem matéria para acusá-lo. Mas Jesus, inclinando-se, escrevia na terra com o dedo. Como insistissem em interrogá-lo, ergueu-se e lhes disse: "Quem dentre vós estiver sem pecado, seja o primeiro a lhe atirar uma pedra!” Inclinando-se de novo, escrevia na terra. Eles, porém, ouvindo isso, saíram um após outro, a começar pelos mais velhos. Ele ficou sozinho e a mulher permanecia lá no meio. Então erguendo-se, Jesus lhes disse: "Mulher, onde estão eles, ninguém te condenou?” Disse ela: “Ninguém, senhor”. Disse, então, Jesus: “Nem eu te condeno. Vai, e de agora em diante não peques mais” (Jo 8, 2-11).
\end{abstract}

Esta é a cena. A mulher não é condenada, pois o poder das palavras pronunciadas por Jesus é capaz de salvá-la: “Quem dentre vós estiver sem pecado, seja o primeiro a lhe atirar uma pedra!” Tais palavras se remetem a uma culpa que provavelmente todos os homens inseridos nessa sociedade teocêntrica sentiram pelo menos uma vez na vida. Somemos a isso o fato de que se considerar sem pecado pode ser em si, o maior dos pecados, pois Deus é o único ser que nunca errou. E, assim, eis que estamos diante da fonte do poder das palavras de Jesus, absoluta, inquestionável. Dos pensamentos que ele tem diante da situação a que foi submetido, nada sabemos: seus pensamentos e sentimentos nos são totalmente obscuros. O narrador, que se caracteriza como uma testemunha dos fatos, não tem acesso à interioridade da personagem. Nesse evangelho, Cristo aparece como um ser distanciado da humanidade, todas as suas ações são consideradas perfeitas, uma vez que se trata de uma deidade, o filho de Deus. O que podemos perceber, dado o contexto em que a história se insere, é que diante da interlocução acima Jesus é o único ser que poderia condenar a adúltera, pois ele, sim, está sem pecado, uma vez que é o cordeiro imaculado de Deus que veio ao mundo para redimir a humanidade. Parece-nos que a importância desse episódio repousa no fato de Cristo salvar a mulher através do poder de suas palavras, vencendo, desse modo, os seus inimigos. Assim, tudo que temos diante de nós nessa narrativa, no que diz respeito à personagem central, são os 
seus atos: de nenhum modo se perscruta a intimidade do herói. Dos fariseus, até sabemos quais são as suas intenções, eles querem desmoralizar Jesus, fazer com que ele desrespeite a Lei de Moisés, para assim terem de que acusá-lo. Cristo, porém, está acima disso tudo, ele se distancia dos homens exatamente pelo fato de ser um deus.

Em O Evangelho Segundo Jesus Cristo, Saramago reproduz esse episódio, acrescentando alguns detalhes que nos mostram um outro Jesus. O “milagre” saramaguiano ocorre antes do encontro do filho de Maria com Deus e o Diabo sob o nevoeiro no Mar da Galiléia, momento em que a personagem ainda não sabia exatamente quais eram os planos de Deus para com ele:

(...) mas o segundo [milagre] teve mais que se lhe diga porque representou um desafio frontal de Jesus à lei escrita e observada, acaso justificável, tendo em conta os comportamentos humanos normais, por viver Jesus com Maria de Magdala sem com ela estar casado, prostituta que havia sido, ainda por cima, por isso não se devia estranhar que estando uma mulher adúltera a ser apedrejada, conforme a Lei de Moisés, e disso devendo morrer, aparecesse Jesus a interpor-se e a perguntar, Alto lá, quem de vós estiver sem pecado, seja o primeiro a lançar-lhe uma pedra, como se dissesse, Até eu, se não vivesse, como vivo, em concubinato, se estivesse limpo da lacra dos actos e dos pensamentos sujos, estaria convosco na execução dessa justiça. Arriscou muito o nosso Jesus porque podia ter acontecido que um ou mais dos apedrejadores, por serem de coração endurecido e estarem empedernidos nas práticas do pecado em geral, dessem ouvidos de mercador à admoestação e prosseguissem no apedrejamento, sem medo, eles próprios, à lei que estavam aplicando, por ser destinadas às mulheres. (...) Jesus disse à adúltera, Vai e doravante não tornes a pecar, mas no íntimo ia cheio de dúvidas (SARAMAGO, 2001, p. 351-2).

Em primeiro lugar, podemos observar que, no romance, ninguém pretende tentar Jesus, ou sequer acusá-lo de algo, não se trata aqui de alguém muito conhecido como no texto bíblico. Ele aparece de repente na cena e, motivado por um sentimento de culpa semelhante ao da adúltera, se interpõe em favor dela. A questão é a mesma apresentada no Evangelho de João: “quem de vós estiver sem pecado, seja o primeiro a lançar-lhe uma pedra”. Porém, o admoestador é tomado de dúvidas, um fato novo em relação ao texto matriz desse episódio. No romance, temos acesso à intimidade da personagem, todos os seus atos e o modo como ele se sente por agir da maneira que age nos são revelados dentro da narrativa. E, na nova versão, o "milagre” se dá mais pelo fato de os lapidadores terem atendido àquele que lhes indagava pelos seus erros, algo que pode ser caracterizado como um golpe de sorte de Jesus, como sugere o narrador, pois os homens que queriam condenar a mulher poderiam sequer lhe dar ouvidos. Fica evidente, no romance, que o Jesus saramaguiano é colocado no mesmo nível dos outros homens, um pecador, e como tal, não se sente à vontade para condenar a mulher, 
uma pecadora como ele e, por isso, a perdoa: “Até eu, se não vivesse, como vivo, em concubinato, se estivesse livre dos actos e dos pensamentos sujos, estaria convosco na execução dessa justiça”, ou seja, se ele pudesse ajudaria os fariseus como um judeu que respeita a Lei mosaica. Ao perdoá-la, Jesus é tomado de dúvidas: “mas no íntimo ia cheio de dúvidas”.

Na narrativa bíblica, Jesus se caracteriza como um ser acima dos demais homens. Seus motivos são inescrutáveis. Até mesmo o significado de seu ato, "Mas Jesus, inclinando-se, escrevia na terra com o dedo", é um dado obscuro na narrativa. Parece que estamos diante da pretensão à autoridade absoluta do texto bíblico que, segundo Auerbach, “não quer nos fazer esquecer nossa própria realidade durante algumas horas (...) mas suplantá-la” (2004, p. 12.). Por outro lado, o Jesus do romance se apresenta como um livro aberto diante de nossos olhos. O que ele pensa e sente diante da condenação da mulher é relatado para o leitor em seus mínimos detalhes: o filho de Maria também está em situação irregular perante a Lei, pois vive com uma mulher sem ser casado com ela, somando-se a isso o fato de ser essa mulher uma ex-prostituta. O herói do evangelho de João não condena a adúltera, embora tenha poder para isso, porque é uma encarnação divina e seu gesto pode significar uma demonstração de sua benignidade. Isso demonstra a sua superioridade em relação aos outros homens, pois ele tem o poder não apenas para castigar, mas também para perdoar. Diferente disso, o Jesus de Saramago não condena a mulher, por perceber a contradição que há em condená-la, encontrando-se, ele, em situação semelhante. É interessante notar como a situação em que a personagem se encontra parece ecoar a referência feita ao episódio em A Relíquia, de Eça de Queiroz, em que o fato de Jesus perdoar a adúltera se deve a sua frouxidão moral e não ao excesso de sua misericórdia, segundo comentário de Gamaliel, uma das personagens do romance queirosiano:

Oh Gad, aos trinta anos o Rabi não é casado! Qual é o seu trabalho? Onde está o campo que lavra? Alguém jamais conheceu a sua vinha? Vagabundeia pelo caminho e vive do que lhe ofertam essas mulheres dissolutas! E que outra coisa fazem esses moços sem barba de Síbaris e de Lesbos, que passeiam todo dia na Via Judiciária, e que vós outros, Essênios, abominais de tal sorte, que correis a lavar as vestes numa cisterna, se um deles roça por vós?... Tu ouviste Osanias, filho de Beothos... Só Jeová é grande! e em verdade te digo que, quando o Rabi Jexua, desprezando à Lei, dá a mulher adúltera um perdão que tanto cativa os simples, cede à frouxidão da sua moral e não a abundância da sua misericórdia!” (EÇA DE QUEIROZ, 1997, pp. 110-1) 
Fica evidente na fala da personagem de A Relíquia o total desprezo por Jesus, a quem ele se refere com ironia e sarcasmo. No entanto, podemos notar que o motivo de Cristo para perdoar a adúltera é semelhante ao que move a figura central do romance de Saramago: em ambos os casos não é a misericórdia que faz com que Jesus a perdoe, como se pode imaginar que seja o caso do Evangelho de João, mas sim uma proximidade do herói da narrativa com a condenada, uma vez que ele comunga com ela do mesmo "pecado". Desse modo, ocorre o rebaixamento da personagem do evangelho: o Cristo, de natureza divina, é humanizado e, assim, temos uma inversão paródica, ou irônica, em relação ao que nos é mostrado no texto original. É interessante notar também que nos textos considerados são três pontos de vista diferentes: no evangelho é o de alguém que se considera testemunha dos fatos e seguidor fiel de Cristo; no romance de Saramago, o ponto de vista, que conhecemos por intermédio do narrador, é o do próprio Cristo; e no caso do romance de Eça de Queiroz, o ponto de vista é o de um inimigo de Jesus.

Assim, o Jesus de Saramago pode ser caracterizado como uma releitura heterodoxa do mito bíblico do messias. No entanto, muitos outros cristos foram criados pela literatura, como procuramos mostrar no primeira parte da presente dissertação. O episódio da mulher adúltera, por exemplo, tem ainda uma outra versão elaborada por Kazantzakis, em A Última Tentação de Cristo. Nesse romance, numa outra versão paródica do capítulo 8 de Evangelho de João, Jesus salva sua prima, Maria Madalena, que não é uma adúltera, mas uma prostituta, condenada pelo povo ao apedrejamento por seus pecados. A célebre frase "Quem de vós estiver sem pecado, que atire a primeira pedra" do quarto evangelista é repetida quase que literalmente. O resultado é o mesmo que o obtido no evangelho e no romance de Saramago: a massa acuada pelo sentimento de culpa recua de sua intenção de apedrejar a moça. No entanto, a personagem Jesus nem sequer se aproxima da figura segura dos evangelhos. No romance de Kazantzakis, Cristo é apoiado diretamente por nada mais nada menos que Judas Iscariotes, muito mais seguro e certo do que pretende do que o próprio Cristo.

Em suma, pretendemos desenvolver nessa parte do trabalho uma análise detalhada do Jesus saramaguiano, tendo em vista, primeiro, suas relações com os outros Cristos vistos acima, uma vez que é factível que essa personagem integre um cânone literário de leituras heterodoxas do mito central da cultura cristã; segundo, o modo como ele se insere dentro do conjunto de personagens criadas no universo romanesco de Saramago. Para isso, passaremos 
a analisar alguns dos principais episódios relativos a história de Cristo, procurando mostrar como eles ocorrem nos evangelhos e são relidos em outras obras literárias, para daí relacionálos com o modo como Saramago relê a vida da principal figura do cristianismo. 


\title{
II. A LITERATURA QUE REVISITA CRISTO
}

\author{
Quand le seigneur, levant au ciel ses maigres bras \\ Sous les arbres sacrés, comme font les poètes, \\ Se fut longtemps perdu dans ses douleurs muettes, \\ Et se jugea trahi par des amis ingrats ; \\ Il se tourna vers crux qui l'attendaint en bas \\ Rêvant d'etre de rois de sages, des prophètes... \\ Mais engourdis, perdus dans le sommeil des bêtes, \\ Et se prit à crier : "Non, Dieu n'existe pas ! » \\ (Le Christ aux Oliviers, Gerard de Nerval)
}

\section{A Biblioteca Virtual}

O nosso interesse nesse trabalho consiste no fato de que as leituras da história contada nos evangelhos fazem parte de um fenômeno cultural bastante recorrente nos últimos dois mil anos nas Artes Plásticas, na Literatura e, mais recentemente, no Cinema. Nosso objetivo do presente trabalho é analisar o processo de elaboração do Jesus de Saramago, considerando um cânone já existente de obras ficcionais que revisitam a história de Cristo. Por conta disso, visamos o estudo de outras obras que possam de alguma forma ter influenciado o escritor na criação desse novo ser ficcional. Romances, contos, poemas e textos, em que Jesus aparece como personagem ou como objeto de estudo, constituem, nesse caso, uma espécie de Biblioteca Virtual, cujos livros, de uma forma ou outra, ecoam em O Evangelho Segundo Jesus Cristo.

Dessa forma, Biblioteca Virtual seria um conjunto de obras que apresentam entre si algumas características em comum e com as quais, de uma forma ou de outra, o romance de Saramago mantém alguma relação de semelhança. Como já dissemos, o tipo de releitura da história de Cristo que encontramos em O Evangelho Segundo Jesus Cristo não se trata de uma novidade na história da literatura ocidental. A história bíblica é lida e relida desde a Idade Média e parece que a partir do século XIX, passou a ser lida de forma heterodoxa, de modo que as novas versões de Cristo contrariam as oferecidas pela tradição cristã.

É possível reconhecer no romance de Saramago ecos de outras obras. Só para pensar apenas em relação à Literatura Portuguesa, o Deus saramaguiano assemelhasse bastante ao apresentado por Guerra Junqueiro em A Velhice do Padre Eterno: um ser egoísta e 
megalomaníaco. As obras que passaremos a apresentar podem ou não ter sido lidas pelo romancista, mas têm em comum com O Evangelho Segundo Jesus Cristo pelo menos o fato de serem uma releitura crítica do mito cristão.

As figuras de Cristo que surgem dessas releituras do mito cristão começam por mostrar um Jesus mais humano, seja tal humanidade total ou parcial. Trata-se de um rebaixamento da principal personagem dos evangelhos do divino para o humano. E mesmo quando o divino reaparece, isso é feito em outros termos, que não o dos evangelhos bíblicos. Essas releituras não reapresentam em nenhum momento o caráter de divina comédia ${ }^{7}$ da história de Jesus, como ela é contada pelos evangelhos bíblicos, pois não se vislumbra um final feliz para essas novas versões de Cristo, que se caracterizam, geralmente, como uma crítica à religião cristã e as mazelas da humanidade a ela atribuídas.

Assim, nosso objetivo a partir dessa idéia de uma biblioteca virtual é fazer um levantamento de textos, cuja intenção é revisitar a história cristã e fornecer uma versão heterodoxa, destoante das versões geralmente aceitas pela religião cristã. A intenção desse estudo é oferecer uma amostragem desse cânone literário não ortodoxo que revisita o mito cristão inicial, dando-lhe novas versões geradas sob um ponto de vista crítico e que, geralmente, tem um caráter humanizador da figura de Jesus.

\footnotetext{
${ }^{7}$ Frye, em $O$ código dos códigos, tece uma crítica à teoria cíclica da história que Yeats constrói a partir do contraste entre os mitos cristão e edipiano. Segundo ele, "Édipo pertence a tragédia e Cristo a uma divina comédia; mas a tragédia reflete a situação humana como ela é, e a comédia normalmente chega ao seu final feliz através de uma reviravolta no enredo". No caso da história cristã, Jesus tem sua morte trágica revertida pela ressurreição, sua vitória sobre a morte. Assim, para o autor é mais fácil pensar no mito cristão como uma versão cômica do mito edipiano (FRYE, 2004, p. 191).
} 


\section{O Jesus dos evangelhos}

O Jesus bíblico, enquanto personagem, caracteriza-se como uma reunião de contrários. Ele é um deus e ao mesmo tempo um homem, no sentido em que ele é feito de carne e osso como todos os outros homens. Ele é o Verbo que se materializou e veio para junto da humanidade para que através de seu próprio sacrifício essa pudesse ser redimida de seus pecados: “E o Verbo se fez carne e habitou entre nós” (Jo, 1, 14).

É factível que os evangelhos são escritos pertencentes à Antigüidade Clássica e, como tais, possuem pontos em comum com os gêneros dessa época. Deste modo, embora elas não sejam poemas épicos, as primeiras narrativas sobre a vida de Jesus são marcadas em relação à escrita contemporânea pelo distanciamento temporal característico da epopéia. De acordo com Bakhtin, o gênero épico é um gênero acabado, isolado em um tempo histórico determinado, pois não pressupõe um futuro e seu passado é absoluto. Para ele, o “discurso épico, por seu estilo, tom e caráter imagético, está infinitamente longe do discurso de um contemporâneo que fala sobre um contemporâneo aos seus contemporâneos” (2002, p. 405). Esse distanciamento temporal do gênero épico em relação à escrita contemporânea também ocorre com os evangelhos bíblicos. Essas narrativas situam-se em um tempo inacessível para nós, em que o mundo representativo das personagens, assim como o conjunto de valores que lhes é inerente, é-nos inevitavelmente estranho. Para penetrar-lhes o sentido é necessário que abandonemos o nosso presente. O herói desses evangelhos surge a partir do mito messiânico, segundo o que Deus enviará um homem para libertar o povo judeu de seus opressores. O destino da personagem não é um destino pessoal, mas está intimamente ligado ao destino de um povo. O herói dos evangelhos, assim como o da epopéia, é um herói coletivo, que, antes de tudo, representa os anseios de um povo, ou mais especificamente neste caso, os anseios da própria humanidade. Assim, a história de Jesus assume os contornos de um destino suprapessoal, que se baseia no mito messiânico do povo judeu, expandindo-lhe o significado, porque o herói dos evangelhos não será o messias apenas para este povo do mediterrâneo, mas para todo os povos do mundo: seu destino é trazer a salvação para toda humanidade. Isto significa que não interessa aqui o indivíduo, pois o herói é a representação viva da história de um povo, ou no caso dos evangelhos, da humanidade.

Como já vimos acima, cada um dos evangelhos apresenta uma versão de Jesus. Assim, 
segundo John Drury, o Jesus de Marcos se caracteriza como um herói de um conto folclórico, de origem popular, que se coloca contra o sistema opressor vigente. Sua função seria a de reordenar os mitos preexistentes:

\begin{abstract}
Segundo Walter Benjamin, o conto folclórico é o modo de a pessoa comum livrar-se do pesadelo que o mito põe em seu peito. O Jesus de Marcos é o herói típico do conto folclórico, um errante que passa por provações que dominam, destroem e reordenam os mitos estabelecidos. Ele é rebelde e não oficial. Ele executa os milagres caros à piedade popular por transformar com um toque o sofrimento solitário em felicidade social; e obviamente esses milagres são suspeitos à filosofia, precisamente por sua realização instantânea dos desejos (DRURY, 1997a, p. 434).
\end{abstract}

O ímpeto narrativo que caracteriza o Evangelho de Marcos se dá pelo fato de que o mais importante para o evangelista é a missão que Cristo veio realizar. "Jesus nascera para ser crucificado” (GABEL \& WHEELER, 1993, p. 175). E é esse o motivo que dá sentido para todos os demais eventos da narrativa. Assim todo o percurso da vida terrena de Cristo se orienta nesse sentido. Para Marcos, ele

foi um taumaturgo, um criador de prodígios e a sua carreira foi como a de um meteoro particularmente brilhante que cruzou, num breve clarão, a escuridão da noite, iluminando este mundo apenas pelo tempo suficiente para indicar que alguma coisa de extraordinária ocorrera (GABEL \& WHEELER, 1993, p. 176).

A dinâmica apresentada por Marcos, marcada pela ausência de longos discursos como, por exemplo, o Sermão da Montanha, encontrado em Mateus, mostra-nos um Jesus mais ativo, que se caracteriza como um herói mais preocupado em realizar suas obras junto à multidão. Ele "parece mais à vontade com os párias: taberneiros, pescadores e leprosos" (DRURY, 1997, p. 444). E é exatamente essa dinâmica da carreira de Jesus apresentada por Marcos e essa identificação direta com as classes excluídas que dão a impressão de que ele veio para romper com a ordem preexistente: Cristo veio para romper tabus e causar estragos na estrutura social vigente. Tudo isso “makes the suffering Son of Man in Mark a model for effective action, not social conformity. Believers are reassured that 'all things are possible to those who believe"” (PERKINS, 1998, p. 249).

Por outro lado, o Jesus de Mateus apresenta um caráter mais conservador em relação à Lei e aos preceitos judaicos, de modo que esse evangelista procura moderar o tom abrupto e impetuoso do Evangelho de Marcos. Para Mateus, Cristo não veio ao mundo para alterar a ordem religiosa vigente, mas para fazer que ela fosse cumprida até seus últimos detalhes. 
Nesse sentido, Jesus

está preocupado não com superação, mas com cumprimento, cumprimento de uma lei que deve permanecer intacta, suas proibições ainda de pé; na verdade, ela deve ser mais estritamente cumprida do que o judeu mais devoto jamais supôs (KERMODE, 1997b, p. 419).

Desse modo, o público de Mateus deveria estar disposto a reconhecer a autoridade do Antigo Testamento em seus mínimos detalhes, a vinda do messias deveria confirmar a Lei e não revogá-la. Como vemos, se o Jesus de Marcos clama por mudanças, o de Mateus reafirma o que já existe. Nas palavras de Gabel e Wheeler ele

é um profeta-mestre judeu cuja autoridade peculiar vem do fato de ser tanto o filho de Deus como descendente direto do rei Davi, reunindo assim em sua pessoa todas as profecias messiânicas das escrituras judaicas (GABEL \& WHEELER, 1993, p. 179).

A narrativa de Mateus é intercalada por uma série de discursos com um desenvolvimento maior do que qualquer coisa do tipo que se possa encontrar na narrativa de Marcos, o que a torna mais cadenciada. Este evangelho se inicia com uma genealogia que pretende apontar Cristo como descendente do rei Davi, através de José, que como sabemos não é na verdade o pai de Jesus. O nascimento, a visita dos reis magos e a fuga para o Egito são os episódios que completam a primeira parte do evangelho e estão cheios de referências ao Antigo Testamento, assim como o restante do livro, que quer se apresentar como um cumprimento das profecias da Bíblia judaica, segundo especialistas, há em Mateus mais de sessenta citações diretas do Antigo Testamento, além de ecos e alusões indiretas a ele ${ }^{8}$.

Em Lucas, Jesus é apresentado como “cumprimento derradeiro da antiga linha profética, predizendo seu fim e o início de uma nova providência na história. Ele é um eixo ou divisor de águas, ponto central no tempo” (DRURY, 1997b, p. 453). De modo que este evangelho possui um caráter universalista, pois não se limita como o de Mateus à afirmação pura e simples da Lei mosaica. A genealogia de Lucas nos remete até ao primeiro homem criado por Deus segundo o mito bíblico, o que pode nos levar a opor Jesus a Adão, sendo que este representa a queda e aquele a restauração do homem. Esta oposição torna-se ainda mais interessante se considerarmos a observação de Frye a respeito da queda e de sua importância para o mito bíblico:

\footnotetext{
${ }^{8}$ Cf. GABEL, John B., WHEELER, Charles B. “Os evangelhos” in: A Bíblia como Literatura, trad. Adail
} 
É a "queda" que introduz a metáfora jurídica que vai persistir ao longo de toda a Bíblia, segundo a qual a vida humana está em julgamento, com promotores e defensores. Nesta metáfora Jesus é o líder da defesa; o acusador chefe é Satã, o “diabolos”, uma palavra da qual deriva a nossa "diabo", e que originalmente guardava o sentido de uma pessoa oposta a outra, num processo legal (FRYE, 2004, p. 140).

Lucas está mais preocupado em desenvolver uma narrativa mais fluente do que com as referências feitas ao Antigo Testamento. Sua intenção é compor sua narrativa dentro de uma perspectiva histórica nos moldes greco-romanos. Segundo Helen Elson, "Lucas é um caso especial [entre os evangelhos] por usar indicadores genéricos greco-romanos explícitos para abalar o conceito grego de história e mostrar que Jesus de fato alterou a natureza ética da vida humana” (1997, p. 606).

Assim, o nascimento de Jesus apresenta uma datação histórica, mesmo que esta seja pouco confiável, como o censo realizado por um édito de César Augusto, citado em Lucas 2, 1. Este censo obrigava que as pessoas fossem se alistar em seu local de origem, de modo que Maria e José tiveram que ir a Belém onde Jesus nasceu, pois José pertencia à casa de Davi. Com isso, o evangelista combina dois fatores, pois ele insere o cumprimento da profecia de que o Messias nasceria em Belém dentro de um dado momento histórico, marcado temporalmente pela referência ao imperador romano e ao governador da Síria, Quirino. Desse modo, segundo Elson, as:

histórias do nascimento exigem assim duas leituras paralelas. Jesus é o salvador do mundo tanto como o Messias da Escritura quanto como o herói cultural greco-romano. Sua vida é um momento decisivo na história; daí a estrutura cronológica e histórica (ELSON, 1997, p. 607).

Ainda na primeira parte de seu evangelho, Lucas apresenta um relato sobre o menino Jesus entre os doutores do templo, sendo este o único trecho em todos os evangelhos canônicos a se referir à infância de Cristo. Aqui vale lembrar que este período na história de Cristo, praticamente ignorado pelos outros integrantes do cânone bíblico, é bastante explorado pelos evangelhos apócrifos e é retomado por vários dos escritores a que vamos nos referir no decorrer desse trabalho, como é o caso de Saramago que dedica um maior número de páginas para relatar o período da vida de Jesus anterior ao seu ministério terreno. No caso dos quatro evangelhos bíblicos, além desse tipo de relato talvez não ter muito sentido, visto os seus 
objetivos, some-se ainda o fato de que o material sobre os primeiros anos da vida de Cristo “era mais anedótico, reunido segundo princípios não narrativos e, portanto, mais difíceis de organizar em uma história coerente e contínua” (KERMODE, 1997b, p. 417). No entanto, este episódio tem outra função no evangelho de Lucas. De acordo com Elson, o evangelista inseriu este dado na narrativa para conformá-la "a um topos biográfico grego que requer que um grande homem deva ter uma infância prodigiosa” (ELSON, 1997, p. 607).

O quarto evangelho apresenta diferenças ainda mais profundas em relação aquelas encontradas entre os três primeiros, conhecidos como sinóticos, que significa "o que pode ser visto conjuntamente”. João apresenta Jesus como se ele estivesse num pedestal, um pouco distante dos assuntos humanos. Ele não tem nada a ver com a figura prática dos sinóticos. Neste evangelho, o filho de Maria é “como alguém num estrado, sempre um pouco elevado e tendente a preocupar-se com os seus próprios pensamentos, só entrando no reino dos assuntos humanos de quando em vez apenas por uma razão especial” (GABEL \& WHEELER, 1993, p. 181).

Vimos até agora como Jesus é caracterizado nos textos fundamentais para sua história. São quatro os evangelhos canônicos e quatro versões diferentes de Cristo. Se nos voltarmos para os apócrifos, observaremos uma variedade ainda maior. Cada autor interpreta essa história a sua maneira e é diante dessa diversidade que surgem novas interpretações das narrativas bíblicas no século XIX. Os textos, que nos interessam aqui, geralmente expõem as contradições existentes nessas narrativas e na religião cristã que as tem como textos fundadores. Vejamos, pois, algumas das diversas versões de Cristo produzidas pela literatura nos últimos duzentos anos. 


\section{Jesus diante da Inquisição: “O Grande Inquisidor”}

Em Os Irmãos Karamazov (1880), romance de Dostoiévski, no capítulo V do livro V, intitulado “O Grande Inquisidor”, uma das personagens elabora uma narrativa em que Cristo retorna ao mundo. Nesse conto, que Ivã Karamazov narra a seu irmão Aliocha, Jesus resolve visitar a humanidade alguns séculos depois de sua primeira estada no mundo. O que ele encontra em seu retorno é uma Igreja construída em seu nome, mas que resulta em algo distinto do que se poderia esperar. O local onde Cristo reaparece é Sevilha, provavelmente no auge Inquisição espanhola:

Oh! Não foi assim que ele prometeu voltar no fim dos tempos, em toda a sua glória celeste, subitamente, "como um relâmpago que brilha do Oriente ao Ocidente”. Não, quis visitar seus filhos, no lugar onde crepitavam precisamente as fogueiras dos heréticos. $\mathrm{Na}$ sua misericórdia infinita, volta ao convívio dos homens sob a forma que tivera durante os três anos de sua vida pública. Ei-lo que desce para as ruas ardentes da cidade meridional, onde, justamente na véspera, na presença do rei, dos cortesãos, dos cavaleiros, dos cardeais e das mais encantadoras damas da corte, o grande inquisidor mandara queimar uma centena de heréticos ad majorem gloriam Dei. Apareceu docemente sem se fazer notar, e - coisa estranha - todos o reconheciam (DOSTOIÉVSKI, 1971, p.186).

Essa aparição de Jesus contraria a previsão segundo a qual ele deveria voltar “em toda a sua glória terrestre” com seus anjos para julgar os homens pelos seus pecados ${ }^{9}$. No entanto, ele prefere visitar seus filhos na mesma forma que tivera séculos atrás. Podemos imaginar, então, que reaparece como um homem pobre, em imediata oposição à riqueza e poder ostentada pelos líderes da Igreja. A glória por ele dispensada é a que poderia ser atribuída a toda corte que, na véspera, estivera naquele mesmo local assistindo as execuções dos hereges. É factível o tom irônico que se volta contra a Igreja, cuja violência perpetrada pela Inquisição contrasta com a "misericórdia infinita” atribuída a Jesus. Luis de Sousa Rebelo, ao comentar esta passagem, observa que Dostoievski "contrastou dramaticamente a obra realizada pela Igreja em quinze séculos de existência com a doutrina pregada por Cristo” (1993, p. 37). Tal oposição entre Instituição cristã e os ensinamentos do filho de Maria é tema também para outros autores dos séculos XIX e XX.

Ao aparecer em Sevilha, Jesus é logo reconhecido pelo povo, embora não faça nenhum esforço para isso, e começa a operar milagres. E é esse mesmo povo, que o reconhece

\footnotetext{
9 “Quando o Filho do Homem vier em sua glória, e todos os anjos com ele, então se assentará no trono de sua glória” (Mt 25: 31).
} 
como fundador da religião a que pertence, que não esboça nenhuma reação quando o Grande Inquisidor ordena que ele seja preso, a multidão age como se não tivesse vontade própria, como se estivesse totalmente alienada do que está acontecendo:

\begin{abstract}
Naquele momento passa pela praça o cardeal, grande inquisidor. É um ancião quase nonagenário, de elevada estatura, de rosto dessecado, olhos cavados, mas a luz ainda uma centelha. Não traz mais a pomposa veste com a qual se pavoneava ontem diante do povo, enquanto eram queimados os inimigos da Igreja Romana. Retomara sua velha batina grosseira. Seus sombrios auxiliares e a guarda do Santo Ofício seguem-no a uma distância respeitosa. Detêm-se diante da multidão e observa de longe. Viu tudo, o caixão depositado diante dele, a ressurreição da menina, e seu rosto ensombreceu-se. Franze suas espessas sobrancelhas e seus olhos brilham com um clarão sinistro. Aponta-o com o dedo e ordena os guardas que o prendam. Tão grande é o seu poder e o povo está de tal maneira acostumado, a submeter-se, a obedecer-lhe tremendo, que a multidão se afasta imediatamente diante dos esbirros; em meio dum silêncio de morte estes pegam e levamno. Como um só homem, o povo todo se inclina até o chão diante do velho inquisidor, que o abençoa sem dizer palavra e segue o seu caminho (DOSTOIÉVSKI, 1971, p.187).
\end{abstract}

Podemos notar que Jesus mantém sua natureza sobrenatural, ele pode realizar milagres, a ressurreição da menina é um exemplo disso. No entanto, sua natureza divina não o torna capaz de lidar com o poder ostentado pelo Grande Inquisidor. Cristo é preso sem ter quem o defenda e é, ironicamente, condenado a morte como inimigo da Igreja Católica, da qual supostamente foi o fundador. O povo, que admira o poder de realizar milagres de Jesus não se manifesta a seu favor diante do poder estabelecido. O grande Inquisidor acaba se tornando aqui uma figura muito mais pujante que o próprio Cristo. Não é o "salvador da humanidade” quem dita as regras, mas a instituição que se edificou tendo como base a sua história. Embora reconhecido como o filho de Deus, Jesus não possui o poder de alterar a realidade, e acaba tendo que se submeter a ela. Sua volta deveria ser triunfal: o juiz que vem ao mundo para julgar os homens por suas iniqüidades. No entanto é ele que está no banco dos réus, como uma ínfima figura, despojada agora de sua divindade e emudecida diante do poder do velho eclesiástico.

O Grande Inquisidor diz a Jesus que a Igreja não foi moldada segundo sua doutrina, que prega a liberdade e o amor ao próximo, isso seria inconcebível para os homens que não nasceram para serem livres: o povo não está à procura de liberdade, mas de um líder. Nesse ponto vale observar um dos modos como Frye caracteriza o pecado original:

Tão logo começamos a pensar, para retomar os termos de Nietzsche, sobre se o limite que aí vemos de fato é um limite, achamo-nos tropeçando na doutrina tradicional cristã do “pecado original”. Esta doutrina sustenta que desde a queda de Adão a vida humana foi amaldiçoada com uma inércia embutida que para sempre impedirá o homem de realizar o 
seu destino sem ajuda divina, e que tal ajuda só pode ser descrita em termos de algo externo e objetivo. A partir do ponto em que aqui chegamos podemos caracterizar a concepção do pecado original de modo mais preciso, como o medo do homem à liberdade e seu ressentimento sobre a disciplina e a responsabilidade que essa liberdade traz consigo (FRYE, 2004, p. 271).

Desse modo, oferecer ao povo a opção de escolha foi o grande erro de Jesus, pois é a própria humanidade que se recusa a abraçar a "liberdade”, uma vez que a teme. Por conta disso, os líderes da Igreja se viram obrigados a refazer o "estrago” que a pregação do filho de Maria fez à humanidade. E eles fizeram isso a partir da orientação demoníaca do ser que tentou Cristo no deserto, oferecendo-lhe o poder e a glória terrenos. O poder sobre os homens que Jesus recusou agora está, ironicamente, nas mãos do Grande Inquisidor que é quem na verdade tem condições para dar ou tirar uma vida, até mesmo a do Filho de Deus, que ele pretende condenar a morte como um simples herege. Outro detalhe importante: os líderes da Igreja se curvam às palavras que o Diabo utilizou para tentar Cristo no deserto e o Grande Inquisidor em maior parte de seu discurso, em que defende veementemente a posição do tentador no deserto, conclui por afirmar que não estavam ao lado do filho de Deus, que desejava a "liberdade do homem", mas ao lado do tentador ${ }^{10}$ :

Cabe a mim esconder-te o nosso segredo? Talvez o queira ouvir de minha boca. Ei-lo: não estamos contigo, mas com ele, desde muito tempo já. Há justamente oito séculos que recebemos dele esse derradeiro dom que tu repeliste com indignação quando ele te

\footnotetext{
${ }^{10}$ O Grande Inquisidor se refere ao episódio da tentação de Cristo, encontrado nos três evangelhos sinóticos, ao qual ele dá valor crucial para a sua posição de que a doutrina pregada por Jesus não tem valor para a Igreja e sim as três perguntas que o Diabo faz no deserto e que resumem o que realmente se passa pelo espírito humano e que foi recusado por Jesus, conforme relata o texto bíblico. Segue abaixo a versão de Mateus, 4, 1-11:

"Então Jesus foi levado pelo Espírito Santo para o deserto, para ser tentado pelo diabo. Por quarenta dias e quarenta noites esteve jejuando. Depois teve fome. Então aproximando-se o tentador, disse-lhe: 'Se és o filho de Deus, manda que estas pedras se transformem em pães'. Mas Jesus respondeu: 'Está escrito:

Não só de pão vive o homem

mas de toda a palavra que sai da boca de Deus.'

Então o diabo o levou a Cidade Santa e o colocou sobre o pináculo do Templo e disse-lhe: 'Se tu és o Filho de Deus, atira-te para baixo, porque está escrito:

Ele dará ordem a seus anjos a teu respeito

e eles te tomarão pelas mãos

para que não tropeces em nenhuma pedra.'

Repondeu-lhe Jesus: 'Também está escrito:

Não tentarás o Senhor teu Deus.'

Tornou o diabo a levá-lo, agora para um monte muito alto. E mostrou-lhe todos os reinos do mundo com o seu esplendor e disse-lhe: 'Tudo isto lhe darei, se, prostrado, me adorares'. Aí Jesus lhe disse: 'Vai-te Saranás, porque está escrito:

Ao Senhor teu Deus adorarás

e só a ele prestarás culto.'

Com isto o diabo o deixou. E os anjos de Deus se aproximaram e puseram-se a servi-lo”.
} 
mostrava todos os reinos da terra; aceitamos Roma e o gládio de César e declaramo-nos os únicos reis da terra, se bem que até agora não tenhamos tido tempo ainda de completar a nossa obra. Mas de quem é a culpa? Oh! o negócio está apenas começado, bem longe de ser completado, e a terra terá de sofrer ainda muito, mas atingiremos nosso fim, seremos césares e então pensaremos na felicidade universal (DOSTOIÉVSKI, 1971, p.192).

Vale observar que a preocupação do clérigo é fundamentalmente com o poder que a religião cristã proporciona a ele e aos seus companheiros, poder este comparado ao gládio de César. É curioso observar que o discurso aqui apresentado se assemelha em parte com o do Deus saramaguiano para quem o sofrimento da humanidade é apenas um detalhe na sua intenção de ser reverenciado por um número muito maior de pessoas que a dos habitantes de um pequeno país do Mediterrâneo.

Interessante notar, também, que Nietzsche, em El Anticristo, de modo semelhante ao de Dostoievski, salienta que o Cristianismo, como conhecemos, não se deve a Jesus, mas a Paulo, que encontrou na religião nascente um modo de sobrepujar às religiões antigas:

(...) entonces apareció Pablo... Pablo, el odio hecho carne, hecho genio, del chandala a Roma, a “el mundo”, el judío, el judío eterno par excellence... Lo que él adivinó fue o modo como, con ayuda del pequeño movimiento sectario de los cristianos, al margen del judaísmo, se podía producir un "incendio mundial”, el modo como, con el símbolo "Dios en la cruz", se podia aglutinar en un poder enorme todo lo que se encontraba abajo, todo lo que secretamente rebelde, la herencia entera de las intrigas anarquistas en el imperio (NIETZSCHE, 2000, p. 115).

Ao atribuir a responsabilidade da elaboração e expansão do que hoje conhecemos como sendo o cristianismo a Paulo, Nietzsche parece isentar Jesus dos “males” oriundos do desenvolvimento dessa religião, pois, embora essa personagem represente o principal símbolo cristão, a doutrina que a Igreja defende não corresponde exatamente aquilo que seu suposto fundador dizia. Para Nietzsche, Jesus acaba se tornando apenas um símbolo, “o Cristo na cruz”, o cristianismo como tal é obra de Paulo. É interessante notarmos que Jesus é posto de um lado e a religião cristã de outro, o mesmo que acontece na narrativa contida em Os Irmãos Karamazov, nos versos de Pessoa e Junqueiro, de que falaremos mais adiante, e em outros textos nos quais Jesus aparece como personagem: a religião que se criou a partir de sua história não reflete a sua própria imagem, a figura de Cristo teve que ser reduzida a um homem na cruz para poder ser mais facilmente digerida pela humanidade. 


\section{Jesus segundo Renan}

Em Vida de Jesus (1863), Ernest Renan tem, inicialmente, como objetivo reconstituir historicamente como poderia ter sido a vida do nazareno, utilizando, para isso, como referência os evangelhos canônicos, aos quais ele denomina "biografias lendárias". Parecenos que sua intenção era oferecer uma visão racional dessa história. Desse modo, deparamonos com tentativas de explicação para os principais fatos narrados nos evangelhos: o nascimento, a vida pública, os milagres, a paixão e o mito da ressurreição, que o autor procura explicar através de uma visão positivista. No entanto, ao considerar quase que exclusivamente os evangelhos canônicos como fonte de caracterização de Jesus, ele acaba criando uma narrativa pouco histórica, pois, apesar de despir a personagem do manto de divindade, acaba por transformá-lo numa lenda, o que parece ser exatamente o contrário de sua intenção inicial. Em outras palavras, Renan é ambíguo em seus objetivos: se por um lado ele propõe uma pesquisa histórica, por outro lado, ele se mantém fiel à narrativa dos evangelhos ${ }^{11}$, gerando, ao invés de um texto histórico, uma outra “biografia lendária”, para usar os seus próprios termos.

Em Mimesis, Auerbach contrapõe as narrativas histórica e lendária. Segundo ele, a narrativa lendária se desenvolve de modo excessivamente liso, tudo o que gera conflito, que confunde o claro curso da ação é desbotado. A história, por outro lado, é mais cheia de contradições e confusão, e seu resultado final sempre leva a um fim de certo modo duvidoso. Parece-nos que essa confusão, essa dúvida, própria da narrativa histórica, não se encontra no texto de Renan, pelo contrário, seu texto é bem ordenado e parece seguir em direção a uma conclusão inequívoca. Sua narrativa, tal como uma lenda:

ordena o assunto de modo unívoco e decidido, recorta-o da sua restante conexão com o mundo, de modo que este não pode intervir de maneira perturbadora; ela só conhece os homens univocamente fixados, determinados por poucos e simples motivos, e que não podem ser prejudicados na inteireza do seu sentir e obrar (AUERBACH, 2004, p. 16).

\footnotetext{
${ }^{11}$ Crossan, em O Jesus Histórico, considera os Evangelhos deficientes como documentos históricos. Segundo ele, os "evangelhos não são nem narrativas históricas, nem biografias (mesmo dentro dos esquemas flexíveis que guiavam estes dois gêneros na Antigüidade). Eles são exatamente aquilo de que passaram a ser chamados mais tarde: Evangelhos, ou 'boas novas'. Daí podem-se retirar duas advertências. O que é 'bom' depende da interpretação ou opinião de um indivíduo ou de uma comunidade. E 'novas' é mais plural do que se pensa” (CROSSAN, 1994, p. 30).
} 
Assim, no livro de Renan, Jesus é apresentado como um camponês judeu durante o Império Romano. Em vista disso, como qualquer um deles, ignorando o caráter divino que a narrativa bíblica confere a figura de Jesus, Renan considera que o filho de Maria aprendeu a ler na sinagoga e dificilmente entendia o hebraico dos escritos judaicos, o que contrasta com o menino entre os doutores no Templo de Jerusalém em Lucas 2, 41-50:

É para crer que aprendesse a ler e a escrever segundo o método do Oriente, que consistia em meter nas mãos da criança um livro, cujo conteúdo repetia a cadência com seus condiscípulos até que pudesse saber de cor. É duvidoso, portanto, que compreendesse bem os escritos hebreus na linguagem original em que foram compostos (RENAN, 1926, p. 25).

Desse modo, Jesus é colocado no mesmo nível de outras crianças em situação semelhante à dele naquela época. Como o filho de Deus, tal como aparece nos evangelhos, Cristo não teria a necessidade de um processo de aprendizagem comum, pois dispunha de uma sabedoria divina, como é destacado no referido trecho de Lucas e por alguns apócrifos, como, por exemplo, o Evangelho Pseudo-Tomé e o Evangelho Árabe da Infância ${ }^{12}$. No entanto, na concepção de Renan, Jesus foi excepcional pelo que representou, e ainda representa, na história da humanidade. De modo que, o autor enfatiza que não é pelo fato de sua pouca formação escolar que Jesus pode ser considerado um ignorante. Naquela época, segundo o escritor francês, não era absolutamente necessária a educação escolar, pois ao contrário da sociedade ocidental, a cultura moral e o espírito geral do tempo eram transmitidos pelo perpétuo contato entre os homens, aludindo-se, assim, a uma cultura de natureza oral. Em suma, Cristo não teve uma boa formação escolar e nenhum contato com a cultura helênica, e a língua pela qual se comunicava era, como no caso de toda a população mais pobre, o aramaico. Podemos inferir, então, que Jesus é um judeu pobre, porém brilhante. O autor não esconde sua admiração pelo homem de quem está falando. O que se refuta neste livro é o caráter sobrenatural dos evangelhos. A idéia de que Jesus quis se passar por uma encarnação divina não é verdadeira, segundo Renan. Para ele, os sinóticos não apresentam nenhum vestígio dessa conjectura. O filho de Maria até mesmo repele essa possibilidade,

\footnotetext{
${ }^{12}$ No capítulo LI do Evangelho Árabe da Infância, o menino Jesus aparece discutindo astronomia com uma inteligência fora do comum: "Havia lá um filósofo, astrônomo sábio, que perguntou ao Senhor Jesus se ele havia estudado a ciência dos astros. E Jesus respondendo-lhe, expôs o número de esferas e de corpos celestes, sua natureza e sua oposição, seu aspecto trinário, quaternário e sêxtil, sua progressão e seu movimento de leste para oeste, o cômputo e o prognóstico e outras coisas que a razão de nenhum homem escrutou” (TRICCA, 2005, p. 175).
} 
apresentando-se pura e simplesmente como filho de Deus, no sentido comum a qualquer outro homem:

\begin{abstract}
Que Jesus nunca pensou em querer passar por uma incarnação do próprio Deus é do que ninguém pode duvidar. Tal idéia era profundamente estranha ao espírito judaico; não há vestígios dela nos evangelhos sinóticos; apenas a encontramos indicadas em partes do evangelho de João, que não podem ser recebidas como eco do pensamento de Jesus. (...) Julga-se superior a um homem ordinário, mas separado de Deus por uma distância infinita. É filho de Deus, mas todos os homens são, ou podem vir a ser filhos de Deus em diversos graus (RENAN, 1926, pp. 196-7).
\end{abstract}

Para Renan, estamos, então, diante de um importante líder religioso que aprendeu com os erros de seus antecessores, entre os quais, Judas Galileu, que comandou uma das várias revoltas judaicas mal sucedidas contra o Império Romano ${ }^{13}$. E, ao meditar sobre esses erros, ele procurou oferecer uma outra via para os problemas enfrentados por seu povo, que transcendesse a organização do mundo em que viviam. Dessa forma, o reino que Jesus oferece não é desse mundo, mas um ideal, o "sábio Jesus, que estava longe de pensar em sedições, aproveitou-se do erro de seu antecessor [Judas Galileu], e meditou outro reino e outro livramento” (RENAN, 1926, p. 50).

Renan chega a dizer que Jesus é, em certo sentido, um anarquista, porque não tem nenhuma idéia de governo civil e de política. Cristo se posiciona contra os ricos e poderosos, pois é contra o acúmulo de riquezas. De certo modo, o escritor francês aponta para uma noção de igualitarismo na mensagem de Jesus, semelhante à descrita por Crossan, segundo o qual, a essência do movimento original do filho de Maria repousa em "um igualitarismo em que se compartilha de bens espirituais e materiais” (CROSSAN, 1994, p. 378).

Em suma, o Jesus de Renan é um homem excepcional que não teve contato com a cultura greco-latina. Dessa forma, ele próprio formulou o seu modo de ver o mundo que de forma alguma pretendeu fazer uso da violência. Cristo, como descrito por Renan, "é um idealista acabado, porque para ele a matéria não é mais do que um sinal da idéia, e o real a expressão viva do que não se vê” (RENAN, 1926, p. 104).

\footnotetext{
${ }^{13}$ A revolta de Judas Galileu aparece em O Evangelho Segundo Jesus Cristo. É após a derrota dos judeus, que indo José ajudar seu vizinho Ananias em sua fuga, acaba sendo crucificado como um dos revoltosos. Depois dessa condenação inicia-se uma nova fase no romance.
} 


\section{Jesus segundo Judas Iscariotes}

Memórias de Judas (1866) se caracteriza como uma narrativa em primeira pessoa, em que Judas Iscariotes narra suas memórias a respeito de uma fracassada revolta contra os romanos planejada por ele e seus comparsas, e em meio a estes eventos, partes de sua vida pessoal, tal como a sua paixão desenfreada por Ida, irmã de Jesus. Trata-se de um romance histórico de qualidade duvidosa. Porém, ele nos interessa na medida que oferece uma nova versão da história de Jesus, que neste romance aparece como um homem comum: ele se caracteriza como um mestre religioso oriundo das classes populares, que Judas, esse sim descendente de família importante entre os judeus, tentou manipular no sentido de que ele mobilizasse as massas para uma rebelião contra os romanos.

As idéias defendidas por Jesus contrariam, segundo o narrador, ao xenofobismo característico da religião judaica: “Trago um novo código que só tem um preceito: os homens são irmãos” (GATTINA, 1946, p. 181). Assim, Cristo é apresentado como alguém que contraria a lei judaica e que pretende modificá-la: “O rabino era mau judeu. Aceitava por favor as nossas leis, nossas tradições, nossos patriarcas, nossos profetas e nossas doutrinas, não as deixando, porém, manter-se” (GATTINA, 1946, p. 207).

O Jesus do romance mantém, até certo ponto, um diálogo com o Cristo dos evangelhos, que em alguns momentos propõe mudanças para a religião judaica e prega o amor entre os homens. O narrador, da mesma forma que os evangelistas, apresenta-se como uma testemunha dos fatos. O que diferencia esse romance de Gattina dos evangelhos bíblicos é, entre outras coisas, o fato de que nessa narrativa nem se cogita a natureza divina de Jesus: ele é um pregador ou profeta em meio a tantos outros que existiam em sua época. No entanto, a revelação feita por Judas de que nenhum dos discípulos acreditava realmente na ressurreição, dá-nos a entender que o conteúdo dos evangelhos canônicos, escritos, como considera a tradição, a partir da lembrança dos apóstolos, não tem o valor de verdade que se lhes atribui, uma vez que não passam de mentiras deslavadas que não se deve a Cristo, mas aos seus discípulos que o abandonaram na hora de sua morte. O romance nega ou reinterpreta o conteúdo dos evangelhos sob um ponto de vista racionalizante: Deus não existe e Jesus é apenas um homem.

Dessa forma, a dessacralização de momentos cruciais na história de Jesus é uma 
constante no decorrer da narrativa. Como exemplo, podemos notar que os milagres neste romance não passam de meros embustes. A ressurreição de Lázaro, por exemplo, que no Evangelho de João tem um papel fundamental na narrativa ${ }^{14}$, pois aparece como um milagre só rivalizado pela própria ressurreição de Jesus, é, no romance de Gattina, um simples despertar de um estado de catalepsia, considerado um verdadeiro e espantoso milagre pelas pessoas que cercavam o Rabi:

Lázaro levantou-se do seu leito, sem dar nenhum sinal de espanto, nem de reconhecimento, e entrou em casa tranqüilamente. Seus amigos, que o acreditavam morto, levaram a notícia a Jerusalém que o rabino de Nazaré o havia ressuscitado (GATTINA, 1946, p. 296).

É interessante notar que Renan oferece uma visão semelhante sobre o episódio da ressurreição de Lázaro. Ele sugere que tudo não passou de uma armação da família de Betania para ajudar Jesus em sua missão, que pode ter inocentemente agido de forma a dar aparência à idéia da ressurreição, uma vez que Lázaro se encontrava doente. Outra hipótese, segundo o autor francês, é a de que a armação pode ter sido feita premeditadamente, como forma de calar a boca dos críticos de Jesus que era amigo da família:

A família de Betania pôde ser levada, quase sem o pensar, ao ato importante que se desejava realizar, porque adorava Jesus. Parece que Lázaro estava doente e que foi a recado das irmãs assustadas que Jesus partiu do Pereu. A alegria de sua chegada deu a vida a Lázaro. Também pode ser que a ânsia de cerrar a boca aos que magoavam afrontosamente a missão divina de seu amigo, levasse estas criaturas apaixonadas além de todos os limites, e que Lázaro, ainda pálido da doença, se enfaixasse como um morto e se encerrasse no seu sepulcro de família. (...) Marta e Maria saíram ao encontro de Jesus; sem o deixarem entrar em Betania, dirigiram-no para a gruta. A comoção que Jesus sentiu perto do túmulo de seu amigo, que julgava morto, podia ser tomada pelos assistentes por aquela torvação, ou estremecimento, que acompanhava os milagres, porque queria a opinião popular que a virtude fosse no homem como um princípio epilético e convulsivo. Jesus (insistindo na hipótese enunciada), quis ver ainda uma vez aquele que tinha amado. Tendo sido removida a pedra, saiu Lázaro com as suas ligaduras e com a cabeça envolvida em uma mortalha. Era natural que essa aparência fosse tida por todos como uma ressurreição (RENAN, 1926, p. 290-1).

Como vemos, os acontecimentos de natureza sobrenatural que ocorrem em torno de

\footnotetext{
${ }^{14}$ Em João, a ressurreição de Lázaro é de suma importância para o desfecho desse evangelho, uma vez que é por conta desse milagre que os líderes do Templo decidem sobre a necessidade de eliminar Jesus, pois ele representava uma real ameaça ao povo judeu, uma vez que seus atos poderiam atrair aos romanos: "Então, os chefes dos sacerdotes e os fariseus reuniram o Conselho e disseram: 'Que faremos? Esse homem realiza muitos sinais. Se o deixarmos assim, todos crerão nele e os romanos virão, destruindo o nosso lugar santo e a nação'. Um deles, porém, Caifás, que era Sumo Sacerdote naquele ano, disse-lhes: 'Vós de nada entendeis. Não compreendeis que é de vosso interesse que um só homem morra pelo povo e não pereça a nação toda?’” (Jo 11, 47-50). A atitude do Sumo Sacerdote será mencionada em A Relíquia, em que se considera como algo louvável o
} 
Jesus, aprecem nesse romance como questões de mera aparência. Não há nenhum episódio que não possa ser explicado racionalmente. Deus existe apenas na crença das pessoas, não apresenta aqui uma existência real. Aliás, nem os próprios discípulos acreditavam realmente no que seu mestre dizia:

Os discípulos, cuja vergonhosa covardia não tinha desculpa, increparam Maria de visionária, quando lhes anunciou que o corpo do rabino "fora tirado do túmulo e que não se sabia onde o puseram”. Eles nunca acreditaram - os néscios - na ressurreição de seu mestre (GATTINA, 1946, p. 362).

A inversão dos papéis entre os discípulos e Judas, o narrador-personagem, que se torna o grande injustiçado da história, pois foi apontado como aquele que traiu Jesus, é evidente quando consideramos os evangelhos. Aqui Judas e Maria Madalena são os únicos que permanecem ao lado de Jesus até o fim, os outros discípulos, os verdadeiros traidores na concepção do romance, abandonam-no e, mais tarde, utilizam sua palavra distorcendo os fatos e criando uma história inverídica.

Outro dado importante da história, a ressurreição de Cristo, considerado por muitos o evento mais importante do Cristianismo, simplesmente não acontece. Jesus é salvo da morte por um ardil de Judas que, no momento da crucificação, deu-lhe um vinho narcotizado que fez com que ele parecesse morto bem antes que os seus companheiros de suplício. Esses, ao contrário da narrativa bíblica, não eram ladrões, mas estavam sendo condenados por tentativa de sedição contra Roma. O estado em que Jesus ficou por ter tomado o vinho evitou que os soldados lhe aplicassem o crucifagium que garantiria a execução. O cenário da crucificação de Cristo é manipulado conjuntamente por Judas Iscariotes e Maria Madalena que salvam Jesus da morte na cruz. Três anos depois ele aparece, em companhia de Judas, na capital do Império Romano:

Há três anos, que o meu amigo definhava. Estava sempre triste, muitas vezes mesmo taciturno. Nunca mais se riu. Raras vezes também falava, evitando sempre qualquer recordação do passado. Não queria ver nenhum de seus conhecidos de outrora. Somente Maria Madalena lhe escreveu três ou quatro vezes, implorando-lhe para deixá-la ir reunir-se a nós em Roma. Meu amigo respondia-lhe muito comovido, muito impressionado, mas ordenando-lhe a permanecer na Síria. Recebeu entretanto um único homem, um certo Saul de Tarso, homem de espírito ilustrado, mas nebuloso e entusiasta. Viu duas vezes o meu amigo e conversou longamente com ele, porém a sós. Depois mais ninguém, mais nada (GATTINA, 1946, p. 363).

fato de se escolher sacrificar um homem, cuja existência poderia ser uma ameaça ao povo. 
O final esplêndido dos evangelhos, que mostra a vitória de Cristo sobre a morte e sua ascensão aos céus, é substituído por um final meramente prosaico no romance de Gattina: Jesus está na capital do Império Romano ao lado de Judas Iscariotes, que foi o único discípulo que não o abandonou na hora da morte. Ali o filho de José recebe correspondências de Maria Madalena, é visitado por Saulo de Tarso, talvez o homem mais importante da Igreja primitiva, e, na visão de vários autores, o verdadeiro responsável pela existência do Cristianismo como o conhecemos hoje. E ao final de sua vida, Jesus recebe ainda a visita de Pilatos, que foi amante de sua irmã. 


\section{Os Cristos de Eça de Queiroz}

\subsection{Jesus segundo um guarda do Templo}

Em 1870, Eça de Queiroz publicou na revista Revolução de Setembro, um conto incompleto intitulado “A morte de Jesus”. Esse conto foi escrito em sua viagem ao Egito e a Palestina em 1869. Nele um homem por nome Eliziel, que se identifica como capitão da polícia do Templo, faz um relato de suas recordações a respeito de Jesus com o seguinte objetivo:

É por isso, para que não se perca a lembrança daquele homem, justo e bom, que eu procuro dizer com simplicidade e verdade tudo quanto vi e compreendi da sua vida tão breve pelos dias, tão longa pelas dores (EÇA DE QUEIROZ, 1999, p. 284).

A justificativa para composição da narrativa pode ser vista como uma inversão do prólogo ${ }^{15}$ do Evangelho de Lucas. No texto bíblico, o narrador alude as várias tentativas de composição da história que vai contar, dando-nos a entender que ela já é bem conhecida em sua época. O narrador do conto eciano, por outro lado, justifica sua narrativa como um meio para que não se perca a lembrança do homem chamado Jesus, cuja memória vai se esvaindo com o tempo: Eliziel está preocupado em produzir um documento para manter viva a lembrança a respeito do homem de quem fala. Tanto que o narrador evoca a memória de várias personagens da história dos evangelhos: “(...) todos esquecidos. Tanto a memória do homem é como a onda fugitiva e pérfida” (EÇA DE QUEIROZ, 1999, p. 284). E no sentido dado pelo conto de Eça de Queiroz, a história de Jesus é apenas mais uma entre outras, que pode até merecer o registro, mas que não tem tanta importância como os evangelhos (riquíssimos em versões, como lembra o próprio evangelista), uma vez que a memória dos fatos vai se esvaindo com o tempo.

O narrador desse conto caracteriza Jesus como um homem justo e bom, mas por nenhum momento fala em seus dons divinos, é como se nem existissem para o capitão da polícia do Templo, que se lembra apenas do pregador a quem tanto admirava pela postura que

\footnotetext{
15 "Visto que muitos já tentaram compor uma narração dos fatos que se cumpriram entre nós - conforme no-los transmitiram os que, desde o princípio, foram testemunhas oculares e ministros da Palavra - a mim também pareceu conveniente, após acurada investigação de tudo desde o princípio, escrever-te de modo ordenado, ilustre Teófilo, para que verifiques a solidez dos ensinamentos que recebeste” (Lc. 1, 1-3).
} 
assumia diante do que considerava injusto e era esta postura, o poder que tinha com as palavras, que o fazia parecer mais que um homem:

Era alto, magro, fraco: tinha os cabelos louros, pendentes, separados ao meio, cabelos de homem da Galiléia: mesmo, percebi logo, pelo acento e pela pronúncia, que ele era Galileu: naquele momento o seu rosto era irritado e severo: tinha o gesto largo ao modo dos que pregam nas sinagogas, tinha as feições inflamadas, os olhos cheios de uma luz indignada: a sua estatura erguida pela cólera, enobrecida pela justiça das palavras, cheia do seu pensamento, fazia-o parecer mais que um homem (EÇA DE QUEIROZ, 1999, pp. 286-7).

Podemos notar a imponência com que Jesus é descrito nessa passagem do conto. O ar de justiça, segundo Eliziel, faz com que ele pareça estar acima da humanidade, mas se trata apenas de aparência e não lhe confere o status de divindade, e tal superioridade é semelhante àquela atribuída por Renan, que o caracteriza como um sábio ${ }^{16}$. Vale lembrar que o modo como Cristo é caracterizado nesse conto difere muito da maneira como ele é apresentado em A Relíquia, como veremos mais adiante: no romance, o homem justo do conto dá lugar a um pregador inconseqüente.

O conto A morte de Jesus remete a vários trechos bíblicos, tais como a expulsão dos vendilhões do Templo e a parábola do fariseu e do publicano, esse último surge como a justificativa do narrador de seu ódio pelos fariseus. Assim, o conto se caracteriza como uma releitura dos evangelhos: vários elementos da narrativa bíblica são utilizados e reorganizados à maneira do autor. Desse modo, ao contrário do que acontece nos evangelhos bíblicos, o nazareno é visto por Eliziel como o possível messias que irá libertar o povo de Israel do julgo romano e não o Filho de Deus que traz ao mundo a possibilidade de redenção dos pecados.

O primeiro capítulo prepara o terreno para a história que será narrada. Eliziel, antes de mencionar como conheceu Jesus, faz uma caracterização do templo e dos grupos que o freqüentavam: os fariseus, os saduceus e os mercadores. Ele demonstra uma imensa antipatia por tais grupos, o que aparece como um dos motivos de sua admiração pelo profeta da Galiléia, sobretudo por esse ter expulsado os vendilhões do templo. Os fariseus e os saduceus, reconhecidos como inimigos de Jesus, são caracterizados como pessoas de má índole, o que

\footnotetext{
${ }^{16}$ Renan coloca Jesus como o mais importante entre nomes que ele considera grandes pela história: “Os homens que mais altamente compreenderam Deus, Çakya-Mouni, Platão, S. Paulo, S. Francisco de Assis, Santo Agostinho, em alguns momentos da sua vida inconstante, eram deístas ou panteístas? Tal pergunta seria um contra-senso. As provas físicas e metafísicas da existência de Deus tê-los-iam deixado ficar indiferentes. Sentiam o divino em si mesmos. Cabe a Jesus o primeiro lugar dessa grande família dos verdadeiros filhos de Deus. Jesus não tem visões; Deus não lhe fala como quem está fora dele; Deus está nele; ele sente-se com Deus e tira do seu
} 
contrasta com o modo como é apresentado o profeta da Galiléia. Esse representa uma resposta aos anseios do povo, abandonado a própria sorte por seus dirigentes. A figura do profeta surge como a de um homem com idéias revolucionárias, que representa uma voz coletiva e que, invariavelmente, é exterminado às portas de Jerusalém, e Jesus é um deles e nada mais que isso. Isto nos leva a pensar na morte trágica de Jesus, que não é apenas igualado aos profetas, mas é apresentado como um homem que traz esperança ao povo e é reprimido pelas classes dirigentes da sociedade, uma espécie de herói popular:

O povo, sufocado pela sua paixão interior, sentia-se aliviado e consolado, quando um profeta falava. Os profetas confirmavam a vinda do Messias, diziam-lhe a figura e as ações, a piedade e a paixão, esfarrapavam os seus vestidos, iam viver no deserto: daí a exaltação tornava-se um estado natural e humano, as almas cresciam em desejo e vontade. De sorte que todos os anos apareciam videntes e inspirados, que o Sanedrim mandava lapidar a porta Esterquilinária (EÇA DE QUEIROZ, 1999, p. 288).

Além das referências aos textos bíblicos, parece haver uma clara influência de $A$ Vida de Jesus, de Ernest Renan. Várias das considerações que ele faz respeito de Jesus são semelhantes às feitas pelo escritor francês, como a sua relação com as mulheres ou até mesmo o modo como Renan caracteriza o Deus de Jesus em oposição à figura opressora e cruel presente no Antigo Testamento, como será fácil perceber nos dois trechos abaixo:

\footnotetext{
O Deus de Jesus não é esse fatal superior que nos mata quando lhe apraz, que nos condena quando lhe apraz, que nos salva quando lhe apraz. O Deus de Jesus é nosso Pai. Ouvimo-lo quando escutamos um ligeiro sopro que grita em nós (RENAN, 1926, p. 63).

O seu Deus não era Jeová, amigo de Israel, inimigo dos homens: não era o ser solitário, tenebroso, irritável: o seu Deus era o pai, o consolador, o purificador, o eternamente sereno, o eternamente justo (EÇA DE QUEIROZ, 1999, p. 294)
}

Podemos pensar que o narrador do conto apresenta a visão de alguém que viveu na mesma época que Jesus, para quem nem se cogitava a hipótese de que o galileu era o filho de Deus. Por outro lado, Eliziel o vê como um homem respeitável por sua postura diante de uma elite social hipócrita, contra a qual se posiciona como crítico de suas injustiças, caracterizando-se, assim, um entre outros tantos profetas que se voltaram contra as injustiças cometidas por essa elite e por isso mesmo perderam suas vidas, mesmo destino de Jesus, que dá o título a esse conto inacabado.

coração que diz de seu Pai” (RENAN, 1926, p. 61). 


\subsection{Teodorico e o Diabo}

Em A Relíquia, Teodorico tem um sonho com o Diabo, que parece surgir como uma espécie de lamentação pelo prazer carnal que é negado à personagem pela figura de sua tia, D. Patrocínio. O Diabo sobe o monte juntamente com Teodorico e suas duas amantes e lhe mostra o cenário da crucificação de Jesus numa estranha mistura com ascensão, em que anjos sobem Cristo ainda na cruz, símbolo máximo do catolicismo, imagem que, aliás, tem seu paralelo em um poema do próprio Eça de Queiroz, citado por Reis na introdução à Prosas Bárbaras, intitulado, "Serenata de Satã às Estrelas”:

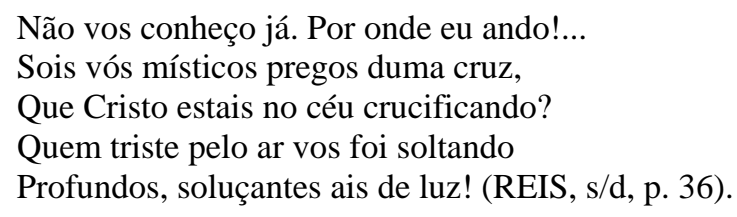

A imagem do Cristo na cruz como símbolo da religião cristã irá surgir também no poema VIII de o "Guardador de Rebanhos”, de Alberto Caeiro, heterônimo pessoano, como veremos mais adiante.

Ainda no sonho de Teodorico, Deus aparece como um "ancião enorme de túnicas brancas” que comanda a ascensão do Cristo crucificado. O comentário do Diabo, ao final da cena é carregado de ironia: "E o Diabo olhando para mim pensativo: 'Consummatum est, amigo! Mais outro deus! Mais outra religião! E esta vai espalhar em Terra e Céu um inenarrável tédio” (EÇA DE QUEIROZ, 1997, p. 67). A religião cristã é colocada no mesmo nível de várias outras. Deus é um entre outros deuses. E o que vem dessa nova religião, a cristã, é visto de um modo depreciativo, pois ela traz consigo "um inenarrável tédio”. O comentário do Diabo se caracteriza como uma profanação de um tema sagrado. No entanto, ele não corresponde exatamente ao anjo caído da religião cristã, uma vez que admite a existência de outras divindades. Podemos pensar que se isso é um sonho, o Diabo que surge é uma projeção da própria revolta de Teodorico diante daquilo que dificulta o seu desejo de herdar a fortuna da tia. Lúcifer, assim, surge como uma entidade que representa um certo modo de pensar, mais bem aceito pelo narrador-personagem, que a própria figura de Deus, pois, parece que ele representa a liberdade do julgo da religião cristã: 
tudo era branco, polido, luminoso e sereno: uma harmonia saía da forma dos mármores, da constituição das cidades, da eloqüência das academias e das destrezas dos atletas: por entre as ilhas da Iônia, flutuando na moleza do mar mudo como cesta de flores, as Nereidas dependuravam-se da borda dos navios para ouvir a história dos viajantes: as Musas, de pé, cantavam pelos vales; e a beleza de Vênus era como uma condensação da beleza de Helênia (EÇA DE QUEIROZ, 1997, p. 68).

O tom favorável às religiões pagãs em detrimento da cristã é o mesmo de $A$ velhice do Padre Eterno, de Guerra Junqueiro, em cujo prefácio, o poeta critica a ascensão de Jeová no lugar que já pertenceu aos mais interessantes deuses gregos. É factível a ironia com que o poeta se refere à ascensão do Deus, que toma o lugar das antigas divindades greco-latinas:

Quem diria que este truculento Sr. Padre Eterno, um pobre Deus semita, desprotegido e bárbaro, um Deus de $4^{\mathrm{a}}$ ou $5^{\mathrm{a}}$ classe, havia de fazer carreira tão longa e tão brilhante! Ele que conhecera Júpiter Todo Poderoso, dominando o Olimpo e trovejando lá de cima: - 'O universo sou eu!' - quando havia de supor que o grande Deus helênico morreria tão depressa, deixando o seu Versalhes sobrenatural, dum luxo quimérico, para ele instalar a sua corte desgrenhada e mística, de profetas e selvagens e de ancoretas cavernosos, calcando uma face de luar e de olhos azuis, úmidos de esperança, fitos na última lágrima da noite - que é a primeira estrela da manhã” (JUNQUEIRO, s/d, p. XX).

É evidente o rebaixamento da figura de Deus nos comentários de Guerra Junqueiro que o caracteriza como uma espécie de usurpador de segunda categoria, que colocado ao lado dos habitantes do Olimpo não passa de um ser grosseiro.

No sonho de Teodorico, outro dado interessante é o fato de que as cores vivas com que o Diabo descreve aos cultos pagãos, aos quais ele atribui prazer e beleza, é substituído por cores mais pesadas e soturnas resultantes do aparecimento do Nazareno:

Mas aparecera este carpinteiro de Galiléia - e logo tudo acabara! A face humana tornara-se para sempre pálida, cheia de mortificações: uma cruz escura esmagando a Terra, secava o esplendor das rosas, tirava o sabor aos beijos das formas (EÇA DE QUEIROZ, 1997, p. 68).

Para Teodorico, Cristo não traz benefícios para a humanidade, mas sofrimento. Nas palavras de Feuerbach, sofrer "é o supremo mandamento do cristianismo” (FEUERBACH, 1994, p. 65). E, assim, seu símbolo mais importante, a cruz, é um peso que sufoca a humanidade, tirando-lhe o prazer, sobretudo, o prazer sexual que se apresenta como um fruto proibido. Essa temática estará presente em autores como Kazantzakis, por exemplo, em que o desejo sexual de Jesus por Maria Madalena é reprimido ao máximo, pois causaria a impureza da personagem, que temia desagradar a Deus. Interessante notarmos que, nesse sentido, o sonho de Teodorico representa seu desejo reprimido, represado pelas regras de uma vida 
religiosa a que ele se submete, para, após a morte de sua tia, possuir riquezas suficientes para viver uma vida libertina. A imagem de Cristo na cruz é, assim, o maior obstáculo para que Teodorico alcance aquilo que ele almeja.

\subsection{Jesus segundo S. Teodorico}

É interessante, antes de prosseguirmos, situar Eça de Queiroz no quadro geral da Literatura Portuguesa do século XIX. Nesse sentido, convém lembrar que Antero de Quental, em um discurso proferido nas Conferências do Cassino em 1871, faz duras críticas ao catolicismo pós Concílio de Trento, apontando a Instituição Católica como um dos entraves para o desenvolvimento da Península Ibérica. Segundo ele, os dogmas do catolicismo aprovados na Contra-Reforma representam um abandono do espírito evangélico, a condenação da razão humana, estabelecendo limites em que "a vontade individual é uma sugestão diabólica” (QUENTAL, 1982, p. 275). A posição tomada por Antero de Quental ao criticar ao catolicismo é compartilhada por alguns de seus contemporâneos, como Eça de Queiroz, Oliveira Martins, Gomes Leal e Guerra Junqueiro. Esse grupo, conhecido como a Geração de 70, em sua crítica à sociedade portuguesa do século XIX, é movido por um forte sentimento anticlerical. Segundo Aparecida de Fátima Bueno, esses autores vão além da crítica contra o comportamento do clero:

Entre as estratégias utilizadas pela Geração de 70 em seu questionamento da sociedade de seu país estava a crítica a atuação e ao comportamento do clero, sobretudo na sociedade portuguesa oitocentista. Movida pelo forte sentimento anticlerical, então bastante revigorado, atenta às várias exegeses bíblicas que vieram a lume na Alemanha e França, essa geração, acompanhando de perto o movimento europeu, vai além da crítica anticlerical, pois culmina por colocar em xeque a divindade de Jesus (BUENO, 2003, p. 55).

É nessa linha que se insere o romance A Relíquia (1887). Nele, Eça de Queiroz apresenta uma outra versão de Cristo. No sonho de Teodorico, no terceiro capítulo do romance, a personagem se vê em Jerusalém em meio ao cenário que caracteriza a narrativa da Paixão encontrada nos quatro evangelhos canônicos. A importância desse episódio é patente para a história do cristianismo e ao contrário dos outros fatos encontrados nos evangelhos, ele apresenta, pelo menos aparentemente, maior coesão. Segundo Crossan, através

de pinturas e esculturas, peças, filmes, citações explícitas e alusões implícitas, de sua 
aceitação ou rejeição, esta saga, passou a ocupar um lugar definitivo no imaginário ocidental. A veracidade narrativa foi aceita como sinônimo de precisão histórica (CROSSAN, 1994, pp. 405-6).

No entanto, a versão apresentada por Eça de Queiroz, em A Relíquia, diverge em vários pontos da narrativa bíblica, não sendo apenas uma alusão, mas uma releitura paródica ou irônica dos acontecimentos ali narrados: Jesus é desdivinizado e até mesmo ridicularizado. E, de certo modo, os judeus tinham razão em matá-lo, pois o filho de Maria, além de não apresentar nenhuma novidade em relação ao judaísmo ${ }^{17}$, representava uma ameaça para o Templo e para Jerusalém, de modo que a atitude dos líderes do templo não é apenas aceitável, mas é até mesmo louvável, pois agiam de forma a proteger o povo de um possível desastre que seria o confronto com os romanos.

O sonho de Teodorico se inicia com seu companheiro de viagem, o douto Topsius, convidando-o para ir a Jerusalém assistir a um grandioso evento, que é nada mais, nada menos que a paixão de Cristo:

D. Raposo! Esta aurora que vai nascer, e em pouco tocar os cimos do Hébron, é a de 15 de Nizão; e não houve em toda a história de Israel, desde que as tribos voltaram da Babilônia, nem haverá, até que Tito venha pôr o último cerco ao Templo, um dia mais interessante! Eu preciso estar em Jerusalém para ver, viva e rumorejando, esta página do Evangelho! (EÇA DE QUEIROZ, 1997, p. 95).

A fala de Topsius, companheiro de viagem de Teodorico, refere-se à importância dessa página do evangelho para a história do Cristianismo. E ele a situa no tempo entre a volta dos Judeus do cativeiro na Babilônia, contado no Antigo Testamento e a queda de Jerusalém no ano 70 da era cristã, de modo que podemos perceber que a visita ao passado não invalida o conhecimento que as personagens têm dos quase dois mil anos de cristianismo, o que não deixa de ser interessante, pois instaura no texto a oposição entre o que é dito pela tradição cristã, bem conhecida pelas personagens, e a nova versão da história que se desenvolve no sonho de Teodorico. É importante dizer que Topsius parece representar a voz da ciência positivista dentro da narrativa: os comentários científicos a respeito do desenrolar dos fatos vêm dessa personagem. É notável a complexidade dessa narrativa que alterna entre sonho e

\footnotetext{
${ }^{17}$ Em Jesus (1967), Flusser defende a idéia de que os ensinamentos de Jesus não tem nada de original, pois, ao fundamentar-se essencialmente na tradição judaica ele reproduz o que outros rabinos judeus já disseram antes dele: “A partir de escritos judaicos antigos poderíamos, com facilidade, construir todo um evangelho sem utilizar uma única palavra que tivesse se originado com Jesus. Isso só poderia ser feito, no entanto, porque possuímos, de fato, os evangelhos” (FLUSSER, 2002, p. 64).
} 
realidade. Assim, o sonho de Teodorico a respeito do episódio da Paixão de Cristo reflete a sua realidade e conhecimentos sobre o assunto. Atribuir a Maria de Magdala a responsabilidade pelo mito da ressurreição é uma idéia proposta por Renan, em Vida de Jesus, que menciona a hipótese de que Jesus não morreu na cruz, como é dito nos evangelhos. Segundo ele, a suspensão na cruz poderia não ser suficiente para a morte de uma pessoa:

É evidente, com efeito, que se suscitaram dúvidas sobre a morte de Jesus. Algumas horas de suspensão na cruz pareciam, às pessoas habituadas a ver crucificações, totalmente insuficientes para tal resultado. Citavam-se muitos casos de crucificados que, desprendidos a tempo, tinham recuperado a vista por curas enérgicas. Orígenes julgou-se obrigado a recorrer ao milagre para explicar um fim tão pronto. O mesmo espanto se nota na descrição de Marcos (RENAN, 1926, p. 345).

Não há em Renan, a preocupação em saber se Jesus ressuscitou ou não. Aliás, a alusão ao fato de ele não ter morrido na cruz já deixa isso bem claro. Como a intenção é buscar uma explicação natural para os fatos narrados pelos evangelhos, o que se tenta explicar mais adiante é como se criou o mito da ressurreição. É aqui que ganha importância a figura de Maria de Magdala, que ao encontrar o túmulo de Jesus vazio, julgou que ele houvesse ressuscitado e saído a espalhar a "boa nova” A ressurreição fica assim vinculada ao amor que os discípulos tinham por seu mestre. E Maria de Magdala teve, na visão de Renan, um papel crucial na criação desse mito, por haver espalhado a idéia do Cristo ressuscitado. É essa a perspectiva exposta no sonho de Teodorico, que surge nas palavras do douto Topsius, comparemos os dois trechos:

No domingo pela manhã as mulheres, sendo Maria de Magdala a primeira, foram, muito cedo ao túmulo. A pedra estava deslocada da abertura e o corpo já não estava no lugar onde o tinham colocado. Ao mesmo tempo espalhou-se pela comunidade cristã estranhas vozes. O grito: "Ressuscitou!" correu por entre os discípulos como um raio. (...) Digamos, contudo, que a imaginação forte de Maria de Magdala desempenhou nesta circunstância um papel de primeira ordem. Divino poder do amor! Momentos sagrados em que a paixão de uma alucinada dá ao mundo um Deus ressuscitado! (RENAN, 1926, p. 349).

Depois de amanhã, quando acabar o Sabat, as mulheres da Galiléia voltarão ao sepulcro, onde deixaram Jesus sepultado... E encontram-no aberto, encontram-no vazio! "Desapareceu, não está aqui!... Então, Maria de Magdala, crente e apaixonada, irá gritar por Jerusalém - "ressuscitou, ressuscitou". E assim o amor de uma mulher muda a face do mundo, e dá uma religião mais à humanidade (EÇA DE QUEIROZ, 1997, p. 160).

A semelhança entre os dois trechos é patente. Maria de Magdala é a primeira a chegar ao túmulo e encontrá-lo vazio, como acontece no Evangelho de João, em que ela é a primeira 
a ver Jesus ressuscitado ${ }^{18}$. No entanto, tanto no romance como no livro de Renan, a ressurreição é fruto da imaginação de Maria de Magdala que, por amar Jesus, julgou que ele tivesse ressuscitado e sai a espalhar o que, por amor, julga ter acontecido, pois encontrou o túmulo vazio e Jesus havia dito que ressuscitaria. Renan alude a possibilidades de que o corpo tenha sido roubado ou que a crença na ressurreição tenha sido forjada. Em A Relíquia, as duas possibilidades se combinam. Um grupo de homens, amigos de Jesus, tinha armado um estratagema para mantê-lo vivo, semelhante ao que ocorre em Memórias de Judas, em que é oferecido a Jesus no momento da crucificação vinho narcotizado, que o faz ter a aparência de morto $^{19}$. Desse modo quando o corpo foi descido da cruz, Cristo ainda não estava morto. Contudo, a tentativa de reanimar o corpo foi frustrada e Jesus morreu na casa de José de Ramatha. O que acontece aqui é semelhante ao desfecho de Memórias de Judas, onde a tentativa de manter o filho de Maria vivo tem maior êxito, tanto que Jesus só morre em Roma três anos depois do calvário, mas vale lembrar que nesse caso Maria de Magdala tem papel ativo na trama para manter Jesus vivo, é ela quem negocia favores junto aos soldados, conseguindo dar-lhe de beber um vinho narcotizado que faria com que Jesus caísse em coma e fosse dado como morto, estando ainda vivo.

Outro fato importante no sonho de Teodorico se refere ao episódio dos vendilhões do Templo. No conto “A morte de Jesus”, o mestre galileu é elogiado pela sua atitude de expulsar os comerciantes do Templo. Com isso, ele faz valer o status de sagrado desse edifício, tal como o que ocorre nos evangelhos bíblicos. No romance, o episódio é relatado por um dos vendedores que se viu prejudicado pela ação devota de Jesus:

Era um pedreiro de Naim, que trabalhara no Templo e nas construções que Ântipas Herodes erguia em Bezetha. $\mathrm{O}$ açoute dos intendentes rasgara-lhe a carne; depois a doença levaralhe a corça, como a grande seca a macieira. E agora, sem trabalho, com os filhos de sua filha a alimentar, procurava pedras raras - nos montes - e gravava nelas nomes santos, sítios santos, para vender no Templo aos fiéis. Em véspera de Páscoa, porém, viera um Rabi da Galiléia cheio de cólera que lhe arrancara o seu pão!...

- Aquele - balbuciou sufocado, sacudindo a mão para o lado de Jesus.

\footnotetext{
${ }^{18}$ Nos evangelhos sinóticos (Mateus, Marcos e Lucas), Maria Madalena está sempre acompanhada de outras mulheres quando vai ao sepulcro na madrugada de domingo. No Evangelho de João, ela é a primeira a ver o sepulcro vazio e também a primeira pessoa a ver o Cristo ressuscitado, sendo, por isso mesmo, quem primeiro anuncia aos discípulos a ressurreição de Jesus. Ver Jo 20, 1-19.

${ }^{19}$ No romance de Gattina Judas Iscariotes manda preparar vinho narcotizado para que Jesus entrasse em coma durante a crucificação e, assim, tivesse a aparência de estar morto: "Prevendo qual seria o desfecho do processo do rabino, mandei preparar um vinho fortemente narcotizado, do qual bastava ele beber algumas gotas, para cair na imobilidade cadavérica do coma. Mandei Maria buscar essa droga à minha casa e eu, com o coração dilacerado pela dor, acompanhei os condenados” (GATTINA, 1946, p. 358).
} 
Eu protestei. Como lhe poderia ter vindo a injustiça e a dor desse Rabi, de coração divino, que era o melhor amigo dos pobres (EÇA DE QUEIROZ, 1997, p. 129).

O vendedor é caracterizado como um trabalhador pobre e doente, que vendia no Templo para ganhar o parco sustento de sua família. A ação de Jesus no Templo agravou sua situação, tirando-lhe uma forma de trabalho. Teodorico não se conforma com a história contada pelo velho, pois como poderia o Rabi, conhecido como melhor amigo dos pobres terlhe causado tamanho mal. Temos dois pontos de vista divergentes nesse episódio, um que julga a partir da tradição cristã, que é o ponto de vista do narrador, e o outro, é o do comerciante de pedras, que estava envolvido no episódio. A idéia de que todo ato de Cristo é perfeito e inquestionável é posto em cheque no romance. Até mesmo os guardas aceitavam que vendedores como o velho com quem Teodorico conversa fizessem seus negócios no Templo, pois sabiam que eles eram pobres e precisavam daquele trabalho. No entanto, Jesus é intolerante em seus princípios não aceitando sequer os argumentos do guarda a favor dos vendedores:

\begin{abstract}
Menahen acudiu também; até, indignado, disse ao Rabi: - "És bem duro com os pobres. Que autoridade tens tu? E o Rabi falou “de seu Pai”, e reclamou contra nós a Lei severa do Templo. Menahen baixou a cabeça... E nós tivemos que fugir, apupados pelos mercadores ricos, que bem encruzados nos seus tapetes de Babilônia, e com o seu lajedo bem pago, batiam palmas ao Rabi... Ah! Contra esses o Rabi nada podia dizer: eram ricos, tinham pago!... (EÇA DE QUEIROZ, 1997, p. 130).
\end{abstract}

Há uma distinção de classe social, ricos e pobres. E o Rabi não vem para mudar a situação, mas parece contribuir para a manutenção dela: ele cobra que a Lei seja cumprida. Nesse sentido, Jesus poderia ser caracterizado do modo como faz Geza Vermes que o considera uma espécie de hassid galileu:

Jesus era um hassid galileu: nisso, a meu ver, reside a sua grandeza, e também o germe de sua tragédia. $\mathrm{O}$ fato de ele partilhar do notório chauvinismo galileu parece claramente demonstrado nas afirmações de caráter xenofóbico que lhe são atribuídas. (...) Mas Jesus também foi, sobretudo, um representante exemplar da religiosidade vivaz e simples que marcava o norte da Palestina (VERMES, 1996, p. 19).

Segundo Vermes, a figura central dos evangelhos não era um homem preocupado com questões de igualdade e justiça, mas sim com a sua religiosidade. Esta caracterização de Jesus diverge da apresentada por Renan, que o mostra como um herói, com as idéias revolucionárias de amor e justiça que promoveram o nascimento do Cristianismo, e da apresentada por Crossan, segundo o qual, a essência do movimento de Jesus consiste em "um 
igualitarismo em que se compartilha de bens materiais e espirituais” (CROSSAN, 1994, p. 378), com base em "uma prática filosófica popular, oral e campesina de algo que poderia ser chamado (...) de um Cinismo judaico” (Idem, ibidem, p. 459). Podemos citar ainda o ponto de vista de Flusser, segundo o qual a noção de justiça divina de Jesus se sustenta em um esquema paradoxal, que não pode ser medido racionalmente, mas ainda sim compreendido pelo homem:

\begin{abstract}
A noção de justiça divina de Jesus é, pois, incomensurável com a razão. O homem não pode medi-la, mas pode compreendê-la. Ela conduz à pregação do reino, no qual o último será o primeiro e o primeiro, o último. Leva também do Sermão da Montanha ao Gólgota, onde o homem justo morre uma morte semelhante a do criminoso. É ao mesmo tempo profundamente moral, e ainda assim, além do bem e do mal. Neste esquema paradoxal, todas as virtudes costumeiras "importantes" e a personalidade bem talhada, a dignidade mundana e a insistência orgulhosa no cumprimento formal da Lei são fragmentárias e vazias (FLUSSER, 2002, p. 77).
\end{abstract}

Entre essas quatro versões de Jesus, a que mais se aproxima de Eça de Queiroz é a de Vermes, para quem as preocupações de Jesus se restringem apenas a questões religiosas, daí considerá-lo um hassid, que significa devotado, amoroso, e nesse caso a preocupação é voltada totalmente ao cumprimento da Lei:

Talvez seja essa concentração exclusiva na tarefa religiosa que tinha imediatamente diante de si, inspirada por um "entusiasmo (nascido da) presença escatológica", para citar outra vez Martin Buber, que explique a total falta de interesse de Jesus pelas realidades políticas e econômicas de sua época. Ele não era um reformador nem revolucionário nacionalista, apesar das recentes alegações em contrário (VERMES, 1996, p. 69-70).

Este Jesus alienado de questões políticas e sociais é o que aparece em A Relíquia, o que não parece ser muito diferente dos evangelhos, só que no romance ele está mais para um fanático religioso. No conto “A morte de Jesus”, embora o narrador o veja com simpatia, devemos lembrar que ele também se recusa a se envolver em assuntos políticos como, por exemplo, liderar uma revolta contra Roma, algo que os judeus da época esperavam de um messias que, supostamente, os libertaria da dominação estrangeira.

\title{
6.4. Cristo, a esperança dos pobres
}

No conto “O Suave Milagre”, publicado por Eça de Queiroz em 1898, vemos um Jesus completamente diferente das outras duas versões apresentadas acima. A narrativa é situada no 
início da carreira terrena de Jesus, momento em que ele ainda não havia saído da Galiléia, se tomarmos como parâmetro a narrativa dos evangelhos sinóticos, nos quais a carreira de Cristo ocorre em apenas um ano, e na qual ele vai a Jerusalém apenas nos momentos que antecedem a sua Paixão: "Nesse tempo Jesus ainda não se afastara da Galiléia e das doces e luminosas margens do Lago Tiberíade (...)” (EÇA DE QUEIROZ, 1945, p. 287).

O conto relata duas buscas infrutíferas por Jesus, uma realizada pelos servos de Obed, um rico fazendeiro da Samaria, que desejava que o filho de Maria revertesse as suas perdas, e outra feita a mando de um centurião romano, cuja filha estava definhando. Nenhuma dessas comitivas encontrou Jesus, nem mesmo através do uso da violência para saber informações de seu paradeiro. No entanto, depararam-se com a fama crescente do rabi da Galiléia, que era conhecido por realizar milagres, motivo pelo qual o procuravam. Para Obed, Jesus era uma espécie de feiticeiro judeu comum nesses tempos na Palestina, ele, portanto, não está atrás de um messias, mas de alguém que possa resolver seu problema mediante um pagamento. Ao fim da narrativa Jesus aparece para a única personagem do conto que não tinha nenhuma condição de ir a sua busca: um menino pobre e enfermo, que ao ouvir falar dele, queria vê-lo.

É factível que o tom pouco religioso de “A morte de Jesus” e A Relíquia não se repete nesse conto. Jesus parece ser visto de um ponto de vista um tanto positivo, no sentido de que ele dá esperança aos pobres, sendo visto como o autor das bem-aventuranças. $\mathrm{O}$ fato de Cristo não ter sido encontrado pelas comitivas do samaritano rico e do centurião romano e aparecer apenas para um menino pobre parece apresentar uma espécie de justiça divina que se coloca ao lado dos excluídos: Jesus está ao lado das “almas simples”. E aqui podemos novamente citar Crossan, que considera que a proposta do evangelho é profundamente igualitária:

O reino de Jesus, que se realizaria no aqui e agora desse mundo, e era composto de gente sem importância ou mesmo indesejável, representava, sem dúvida alguma, uma proposta profundamente igualitária. Sendo assim ele tornava todas as distinções de ordem social, política e religiosa completamente irrelevantes e anacrônicas (CROSSAN, 1994, p. 335).

Podemos notar que Jesus não aparece para os ricos senhores que o estão procurando, que o conhecem apenas através dos relatos a respeito dos milagres por ele realizados. Sua fama é toda construída entre os pobres para os quais ele significa alento e esperança:

Um dia um mendigo entrou no casebre, repartiu do seu farnel com a mãe amargurada, e um momento, sentado na pedra da lareira, coçando as feridas das pernas, contou dessa grande esperança dos tristes, esse Rabi que aparecera na Galiléia, e de um pão no mesmo cesto fazia sete, e amava todas as criancinhas, e enxugava todos os prantos, e prometia aos pobres 
um grande e luminoso Reino, de abundância maior que a Corte de Salomão (EÇA DE QUEIROZ, 1945, p. 296).

Em “O suave milagre”, como podemos ver, Eça de Queiroz parece retomar o Cristo bíblico. Esta narrativa não apresenta o caráter irônico presente em A Relíquia, em que Jesus é, de certo modo, um fanático religioso. Aqui, ele parece o ser divino presente nos evangelhos, que se posiciona em favor dos pobres e oprimidos. 


\section{Jesus e o Padre Eterno em A Velhice do Padre Eterno}

Em A Velhice do Padre Eterno (1885), Guerra Junqueiro assume uma postura anticlerical, típica do grupo conhecido como a Geração de 70, entre os quais temos Antero de Quental, Eça de Queiroz e Oliveira Martins. O livro é composto de 28 poemas em que se tece uma crítica irônica e mordaz contra a instituição católica e os símbolos que a representam. Interessa-nos, sobretudo, o modo como o poeta elabora as figuras de Deus e Jesus em meio ao estado de coisas que caracterizam a Igreja Católica como decadente e corrupta.

Nessa obra, Guerra Junqueiro procura desconstruir a figura do Deus todo-poderoso, apresentando-o como um ser decadente e corrupto à imagem da Igreja Católica. Para o poeta, o Padre Eterno continua bem vivo e disposto a enterrar toda a humanidade: "Confesso-o. Causa-me horror o Deus sanguinolento e fúnebre que separou o homem da natureza, que disse ao filho: - Cospe em tua mãe!” (JUNQUEIRO, s/d, p. XX). Ele se refere, assim, ao atraso moral e social sustentado pela crença na existência de Deus. Assim como Junqueiro, Antero de Quental também aborda o tema seu poema em “Disputa em Família”, composto por dois sonetos, em que ele caracteriza Deus como um ser banal, uma vez que os homens experimentaram os frutos da verdade:

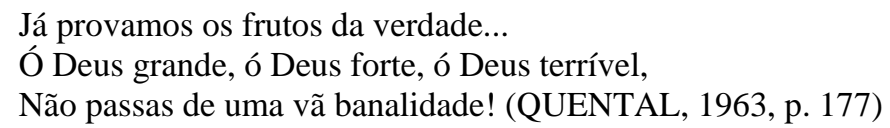

O segundo verso coloca de forma decisiva a figura de Deus que aparecerá em várias das releituras do mito central do cristianismo vistas nesse trabalho. Trata-se de um ser extremamente poderoso e que causa temor, tal como o Deus do Antigo Testamento. O tema de que Antero de Quental tratará em vários de seus sonetos, entre eles, “A Idéia”, é a morte de Deus, o momento em que a razão é celebrada em detrimento do sentimento religioso:

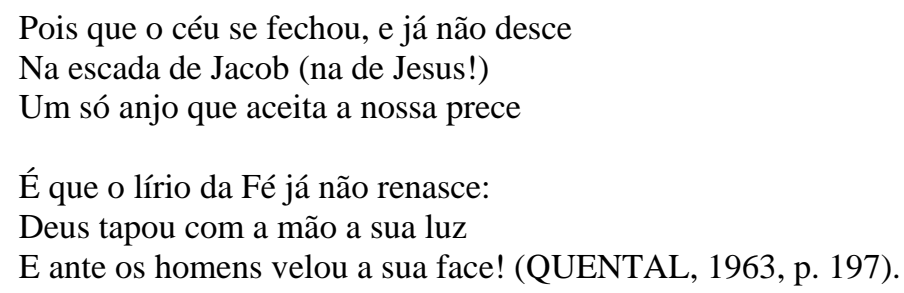

É com os românticos que se apresenta o tema da morte de Deus e que se abre caminho 
para as releituras heterodoxas da vida de Jesus. O que os versos de Quental apresentam é o predomínio da razão em detrimento da fé religiosa que sustenta a existência divina: se não há fé, não há Deus. Em “Le Chrit aux Oliviers”, de Gerard de Nerval, é o próprio Cristo que anuncia a morte de Deus, dizendo que depois de percorrer os mundos a sua procura, não encontrou nada mais uma imensidão negra:

\author{
» En cherchant l'oeil de Dieu, je n'ai vu qu'une orbite \\ Vaste, noire et sans fond, d'ou la nuit qui l'habite \\ Rayonne sur le monde et s'épaissit toujours ; \\ » Un arc-en-ciel étrange entoure ce puits sombre, \\ Seuil de l'ancien chaos dont le néant est l'ombre, \\ Spirale engloutissant les Mondes et les Jours ! (NERVAL, 1964, p. 67).
}

É nesse contexto literário que se insere Guerra Junqueiro com seu livro A Velhice do Padre Eterno. Sua crítica contra o Deus judaico-cristão é virulenta. O poeta caracteriza-o como um ser covarde e sem escrúpulos, que teve a coragem de deixar morrer o próprio filho $^{20}$, para disso obter dividendos, pois estendeu os seus domínios a uma parcela bem maior da humanidade, idéia que estará presente em O Evangelho Segundo Jesus Cristo, em que a “economia da redenção” surge como uma forma de Jeová estender seus domínios sobre o gênero humano, tal como Junqueiro coloca em seu prefácio:

E Jeová na cama, pensou: - Este meu Filho, como todos os grandes gênios é um idiota. Divino imbecil! Deixei-o crucificar, e ele, em recompensa, faz de mim - pobre Deus de Jerusalém - o Deus do Universo inteiro!

E ao outro dia o Padre Eterno instalou-se no Olimpo. (JUNQUEIRO, s/d, p. XXIV).

A imagem ridícula que Junqueiro atribui a Deus ressurge no poema VIII de O Guardador de Rebanhos, onde Deus é caracterizado como “um velho estúpido e doente”, de modo que sua figura de todo-poderoso é rebaixada ao nível de um reles mortal. Podemos notar também que o papel do antigo Senhor dos exércitos sofre uma inversão nesse tipo de leitura do mito cristão, uma vez que Deus não está mais ao lado do homem, sendo considerado muitas vezes seu verdadeiro inimigo, papel que a tradição cristã sempre atribuiu

\footnotetext{
${ }^{20}$ O abandono de Jesus por Deus também aparece nos versos de Antero de Quental, no poema "Disputa em Família”:

Mas o velho tirano solitário, De coração austero e endurecido, Que um dia, de enjoado ou distraído, Deixou matar seu filho no Calvário (QUENTAL, 1963, p. 178).
} 
ao Diabo, sendo “inimigo” um dos modos como ele é conhecido. Na verdade, a idéia de um Deus tenebroso já está presente no Antigo Testamento, só que no texto bíblico as ações divinas nunca são questionadas, tudo o que Deus faz é para o bem do homem. Na poesia de Junqueiro, no entanto, o Deus todo-poderoso e horrível é igualado a um tirano cruel e egoísta. Essa inversão se repete em vários outros textos, tais como A Última Tentação de Cristo, Muerte de Ahasverus e o próprio romance de Saramago, em que há momentos nos quais o Diabo (Pastor) aparece defendendo a humanidade de Deus, como no encontro do Mar da Galiléia em que ele sugere ao seu Criador uma reconciliação a fim de que pudesse se evitar o derramamento de sangue e o sofrimento dos homens previstos com a criação do cristianismo. É importante notar também que Deus é colocado, no prefácio de Junqueiro, ao lado de outros deuses pagãos, de modo que não é mais o Deus único do judaísmo e do cristianismo, mas aparece como mais uma divindade entre tantas outras. Em uma das odes de Ricardo Reis, heterônimo pessoano, essa idéia é reafirmada:

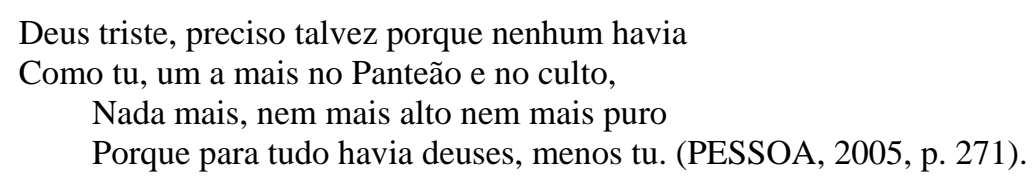

Como um deus entre os outros, o Jesus que Junqueiro apresenta se caracteriza como uma figura alienada do resultado de sua passagem pelo mundo. A referência feita a ele no poema “A Vinha do Senhor” é, inicialmente, positiva. A existência de Cristo irradia uma luz que modifica as pessoas, que dá esperança. Essa vinha pode ser talvez uma alusão aos primeiros anos do Cristianismo: "Produzia um licor balsâmico, divino”. A história de Jesus que, no início da era cristã, era um sonho de belos ideais, vale lembrar que para Renan, toda a história do cristianismo nascente caracterizava-se como um delicioso drama pastoril, que criou na imaginação popular sublimes ideais ${ }^{21}$, tornou-se, com o passar do tempo, em um tipo de bebedeira, de modo que o que era belo se transformou em pesadelo. O corromper desse

\footnotetext{
${ }^{21 ،}$ Toda a história do cristianismo nascente tornou-se por esta forma um delicioso drama pastoril. Um Messias nos banquetes de núpcias, a mulher mundana e o bom Zaqueu, convidados para os seus festins, os fundadores do reino dos céus com um cortejo de paraninfos; aí está o que empreendeu a Galiléia, e o que ela fez aceitar. A Grécia traçou da vida humana, por meio da escultura e da poesia, deliciosos quadros, mas sempre sem fundos fugitivos, e sem horizontes longínquos. Aqui faltam os mármores, os excelentes obreiros, a língua delicada e polida. Mas a Galiléia criou no estado da imaginação popular o mais sublime ideal; porque por detrás do seu idílio agita-se a sorte da humanidade, e a luz que ilumina o seu quadro é o sol do reino de Deus” (RENAN, 1926, p. 55).
} 
ideal gerou o catolicismo, contra o qual o poeta se volta. A crítica ferrenha de Guerra Junqueiro é, essencialmente, contra a instituição cristã. Ele não está muito interessado pela história de Jesus, mas sim em atacar a religião que se formou a partir dessa história. Em outras palavras, o alvo de suas críticas não é exatamente o ideal cristão primitivo, mas o que se desenvolveu a partir disso:

Que o êxtasis cristão tornou-se em bebedeira,

E o sonho em pesadelo, e o pesadelo em crime. (JUNQUEIRO, s/d, p. 15)

Em “A Semana Santa”, Voltaire cansado de “dormir no horror da sepultura” ressuscita e em uma sexta-feira santa sai a percorrer pelas ruas de Londres e ao ver o modo como está a humanidade resolve despertar Cristo para mostrar-lhe o que é feito da Igreja que ele fundou:

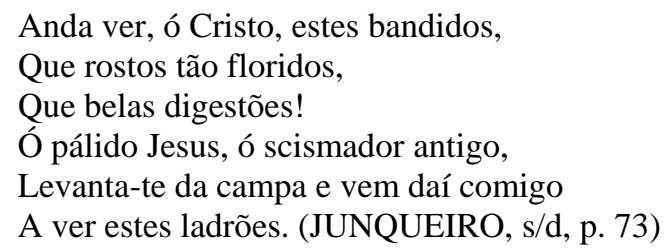

O convite é feito com uma certa dose de ironia e sarcasmo. Voltaire convida Jesus para ver como se comporta o clero. E Cristo é chamado de um cismador, o responsável pela formação de uma nova religião a partir do rompimento com uma outra, nesse caso, o judaísmo. E, nesse sentido, ele é colocado ao nível de qualquer outro cismador da história como, por exemplo, Lutero e não como a figura divina que é o centro da religião cristã. Talvez porque a figura de Jesus é, na visão do poeta, utilizada pelo clero como um meio de alcançar seus próprios objetivos, fato aludido no poema "Parasitas":

Eu lembrei-me de vós, fonâmbulos da cruz, Que andais pelo universo, há mil e tantos anos, Exibindo, explorando o corpo de Jesus (JUNQUEIRO, s/d, p. 41).

Jesus é caracterizado como uma figura bruta, que não se encaixa nos padrões da sociedade cristã. Voltaire, ironicamente, explica-lhe como ele deve se vestir e como deve agir para andar tranqüilamente pelas ruas de Londres sem parecer um pobre palhaço. O rebaixamento da figura de Cristo se evidencia a cada verso. Trata-se apenas de um visionário, do mundo que ele idealizou não existe a menor sombra. Há o catolicismo das procissões, em que Jesus morre na sexta e ressuscita no domingo todos os anos, e isso é tudo que sobrou dele. 
Os integrantes da Igreja fundada em seu nome são corruptos que se aproveitam da sua posição para obter os mais diversos favores:
Ali tens meu amigo, os cônegos vermelhos: Que rostos joviais, brunidos como espelhos, Que riso debochado e gesto violento! E à noite, a esta hora, uns padres sem batinas Decerto não virão pregar às concubinas O $6^{\circ}$ mandamento. (JUNQUEIRO, s/d, p. 84)

O ataque virulento ao comportamento do clero é evidente nesses versos e segue na mesma linha de O crime do Padre Amaro, de Eça de Queiroz, em que Amaro, um pároco provinciano, mantém relações ilícitas com a filha de sua hospedeira. A sua posição como chefe da Igreja local é um dos atrativos para que a jovem se interesse por ele.

Ao fim dessa deambulação Jesus fica diante de um cenário que fere o ideal pelo qual se sacrificou. Isso provoca nele uma reação que é a de Cristo expulsando da Igreja, como um “visionário truculento, febril, colérico, incendiário”, os próprios cristãos e o papa. Podemos notar que os integrantes da Igreja são equiparados aos supracitados vendilhões do Templo. O que podemos perceber aqui é que o Jesus desse poema é isento da responsabilidade pelo que se transformou a religião cristã. Ele era um visionário e sua intenção era outra. De modo que essa Igreja e ele são duas coisas distintas. E isso se comprova pela advertência de Voltaire em certa altura do poema de que se ele fosse reconhecido como Cristo seria novamente crucificado. O mesmo ocorre em “O Grande Inquisidor”, de Dostoievski, e na peça Jesus Cristo em Lisboa, de Raul Brandão e Teixeira de Pascoaes, como veremos mais adiante, onde Cristo volta ao mundo e ao ser reconhecido é novamente condenado à morte. 


\title{
8. O menino Jesus: Fernando Pessoa
}

No poema VIII de $O$ guardador de rebanhos, de Alberto Caieiro, em um sonho no meio do dia, o poeta vê Jesus descer do céu e se transformar em um menino. Ele tinha fugido, pois já não agüentava viver como a terceira pessoa da Trindade. Os versos da segunda estrofe parecem remeter a artificialidade do rito católico, que apresenta um Cristo que todos os anos é crucificado, muito semelhante ao Cristo, tedioso e monótono, que sobre crucificado aos céus em um dos sonhos de Teodorico analisado acima:

\author{
No céu tinha que estar sempre sério \\ E de vez em quando de se tornar outra vez homem \\ E subir para a cruz, e estar sempre a morrer \\ Com uma coroa toda à roda de espinhos \\ E os pés espetados por um prego com cabeça, \\ E até com um trapo à roda pela cintura (PESSOA, 2005, p. 209).
}

A alusão ao ritual católico da Semana Santa pode ser notado pela locução adverbial de tempo “de vez em quando”, que aponta para algo realizado periodicamente. Em A Velhice do Padre Eterno, de Guerra Junqueiro, temos a referência às procissões, cuja imagem não é muito diferente da apresentada por Caeiro. O menino Jesus surge em contradição a essa imagética própria do catolicismo, que se repete continuamente. O Jesus pessoano se caracteriza, assim, como uma desmitificação do mito evangélico representado pelo drama da Paixão que, segundo Eliade, constituí o centro da vida religiosa para os cristãos:

Mas é obvio que, para os cristãos de todas as confissões, o centro da vida religiosa é constituída pelo drama de Jesus Cristo. Embora representado na História, esse drama possibilitou a salvação; conseqüentemente, existe apenas um meio de obter a salvação: repetir ritualmente esse drama exemplar e imitar o modelo supremo, revelado pela vida e pelo ensinamento de Jesus. (ELIADE, 2004, p.146).

Como vemos, a imitação e o ritual são fatores importantes para o cristianismo. O poeta não deixa de notar isso e, desse modo, quando o menino Jesus resolve fugir da vida monótona e antinatural que tem no céu, ele toma o cuidado de criar um Cristo eternamente na cruz que servisse de modelo às outras usadas no ritual católico:

Ele foi a caixa de milagres e roubou três.

Com o primeiro fez que ninguém soubesse que ele tinha fugido.

Com o segundo criou-se eternamente humano e menino.

Com o terceiro criou um Cristo eternamente na cruz

E deixou-o pregado na cruz que há no céu 
O Jesus de Pessoa procura se desvincular do ritual religioso que representa um autêntico mito, nas palavras de Eliade. Cria-se então uma oposição entre o Cristo religioso, que se apresenta como uma imagem repetida ritualisticamente "de vez em quando", e o menino Jesus, que se comporta como um modelo de criança que de tão humana e natural é, por isso mesmo, divina. Essa recusa do poeta em relação ao ritual católico, que procura repetir o drama exemplar do cristianismo resulta na desmitificação da figura de Jesus:

Ao proclamar a Encarnação, a Ressurreição e a Ascensão do Verbo, os cristãos estavam convictos de que não apresentavam um novo mito. Na realidade, eles se utilizavam das categorias do pensamento mítico. Evidentemente, eles não podiam reconhecer esse pensamento mítico nas mitologias dessacralizadas dos pagãos eruditos seus contemporâneos. Mas é óbvio que, para os cristãos de todas as confissões, o centro da vida religiosa é constituído pelo drama de Jesus Cristo. Embora representado na História, esse drama possibilitou a salvação; conseqüentemente, existe apenas um meio de se obter a salvação: repetir ritualmente esse drama exemplar e imitar o modelo supremo, revelado pela vida e pelo ensinamento de Jesus. Ora, esse comportamento religioso faz parte do pensamento mítico autêntico (ELIADE, 2004, p. 146).

A desmitificação de Jesus ocorre na recusa do modelo mítico proposto pelos evangelhos. E por conta disso, o Cristo na cruz é transformado pelo poeta em um menino que almeja viver tão somente como um menino.

Nas imagens que se seguem, figuras importantes para o cristianismo são dessacralizadas. Deus é descrito como um “velho estúpido e doente”, imagem contrária à idéia de perfeição que é ligada ao que ele representa como o ser que criou o universo. A Virgem Maria tem uma vida monótona e o Espírito Santo é uma pomba estúpida. Todas essas figuras são ridicularizadas pelo menino Jesus, que considera que tudo no céu é estúpido como a Igreja Católica. Outra vez estamos diante de uma caracterização de figuras importantes para o Cristianismo, que lembra o tom sarcástico de Guerra Junqueiro, como podemos ver no poema “O Papão”:

As crianças têm medo à noite, às horas mortas, Do papão que as espera, hediondo, atrás das portas, Para as levar no bolso ou no capuz dum frade. Não te rias da infância, ó velha humanidade, Que tu também tens medo ao bárbaro papão, Que ruge pela boca enorme do trovão, Que abençoa os punhais sangrentos dos tiranos, Um papão que não faz a barba há seis mil anos, E que mora, segundo os bonzos têm escrito, 
Esse poema apresenta, como os outros textos que estamos estudando, uma outra imagem de Cristo que não corresponde a da ortodoxia cristã. No entanto, o menino Jesus não é totalmente humanizado como ocorre em outras releituras do mito cristão. Para Eduardo Lourenço, o menino Jesus de Caeiro-Pessoa "põe termo a um longo processo de desdivinização de Cristo e redivinização num sentido novo (religiosidade nova) de Jesus, oposto desde Antero (via Renan) ao Deus bíblico” (LOURENÇO, 1986, p. 117). Desse modo, Cristo pessoano é o divino que é humano, talvez como um reflexo da própria essência do eu poético:

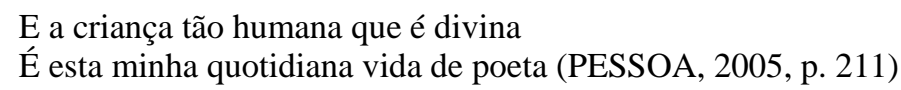

O menino Jesus, “o deus que faltava”, é, parece-nos, o reflexo da existência do próprio poeta. Ele pode representar, talvez, a essência divina que é, nas palavras de Feuerbach, o sentimento de si do homem liberto de toda a contrariedade, como já dissemos acima. O Jesus de Pessoa (Caieiro) se contrapõe ao dogma católico, para ele a vida não tem mistério e tudo que a natureza apresenta vale a pena. 


\section{Jesus nas ruas de Lisboa}

Na peça Jesus Cristo em Lisboa, de Raul Brandão e Teixeira de Pascoaes, Deus envia Jesus novamente ao mundo, pois "os pecados dos homens bradaram aos céus”. E tudo acontece como da primeira vez. Cristo atrai o povo com a realização de milagres, mas causa a revolta das classes dominantes que o vêem como uma ameaça a sua posição, de modo que resolvem eliminá-lo, mesmo o reconhecendo como um Deus. E a melhor forma que eles acham matar um Deus é, significativamente, crucificando-o. No entanto, Cristo ressuscita novamente, como aconteceu há dois mil anos e, da mesma forma, reaparece aos mais pobres e, diante deles, reascende aos céus: tudo como da primeira vez. Segundo Bueno, o(:)

\footnotetext{
Jesus personagem da peça comporta-se, de modo geral, da maneira como foi fixado pela tradição bíblica. Porém, é na reação negativa e na contestação dos outros personagens à sua palavra que podemos verificar um rebaixamento desse Cristo (BUENO, 2003, p. 57).
}

Assim, a primeira aparição de Jesus é feita aos mais pobres que rapidamente ficam entusiasmados com suas palavras. Da mesma forma, a primeira intervenção contra Cristo é feita justamente por um pároco que o considera, após ouvi-lo, como uma ameaça à ordem estabelecida: "Pode ser um homem perigoso. Sabe falar aos desgraçados” (BRANDÃO \& PASCOAES, 1984, p. 32). A figura de Jesus é novamente separada da Igreja Católica, um e outro não falam a mesma língua. Parece-nos, também, que o Jesus dessa peça se apresenta tal qual o do Evangelho de Marcos que, como já dissemos acima, pratica milagres caros à piedade popular, transformando a dor em felicidade social. E aqui Cristo atrai boa parte do povo pela realização de milagres e por dizer palavras que lhe transmitem esperança. No entanto, há reações contra os seus atos e as palavras que ele prega. Um homem o considera intolerável porque ele diz a verdade:

Esta velha, sr. comissário, não sabe o que diz. Eu sei o que digo. O pior de tudo não são esses casos vulgares. O pior de tudo é que este homem prega a verdade. Ora, eu perguntolhe, sr. Comissário, quem é que pode com a verdade! Se eu me pusesse a dizer a verdade a cada um das pessoas que conheço, já estava na cadeia. E se ele se põe a dizer a verdade, acaba-se o mundo. A verdade é uma mentira (BRANDÃO \& PASCOAES, 1984, p. 45).

A acusação, como vemos, é a de que ele diz a verdade, embora será possível perceber mais adiante de que ninguém sabe realmente qual é essa verdade, que nessa fala é, paradoxalmente, uma mentira. O fato é que Jesus aparece como uma espécie de consciência 
que fala contra a injustiça que impera nessa sociedade: “O que Ele diz, sabemo-lo nós todos. Estamos fartos de saber. Ouvimo-lo talvez nas nossas consciências” (BRANDÃO \& PASCOAES, 1984, p.65). É notável que os governantes, no quarto ato, sabem exatamente do que Jesus prega, o problema é que essa voz que fala em suas consciências agora se dirige para o povo. Eis o principal motivo para que ele se torne uma ameaça. A palavra de Cristo pode resultar em uma sociedade sem diferenças de classes sociais, o que representa uma ameaça intolerável à classe dominante. A rejeição de Jesus na peça pode talvez ser pensada também no termos de Frye. Para ele, o significado real da vida do filho de Maria pode ser "o da única figura na história para quem não há sociedade humana que possa tolerá-la” (FRYE, 2004, p. 165).

Nessa peça, o Diabo também aparece como personagem. No quinto quadro, ele entra em cena para tentar Jesus novamente, tal como a tentação no deserto, contada nos Evangelhos sinóticos. No entanto o Diabo não oferece a Cristo os reinos da terra como faz nos Evangelhos Sinóticos, mas tenta, principalmente, convencê-lo de que o homem está melhor com ele do que com Cristo:

O homem não pode contigo. Há milhares de anos que ele faz um esforço para chegar ao céu, para construir uma vida artificial, que não existe! Há milhares de anos que se rasga e dilacera! Há milhares de anos que recalca, sem a poder extinguir, a vida inferior, o subterrâneo que teima em vir a superfície. Há milhares de anos que mente a si mesmo e que finge diante do Universo. Que mais exiges tu dele? (BRANDÃO \& PASCOAES, 1984, p. 78).

A idéia acima é semelhante a do encontro entre Deus, o Diabo e Jesus no Mar da Galiléia, em O Evangelho Segundo Jesus Cristo, de José Saramago. Com o cristianismo, o homem vive para escapar ao pecado que nunca se extingue. Aqui a pergunta é feita a Jesus que não apresenta resposta, nem mesmo algo semelhante ao que ocorre nos evangelhos, onde Cristo cita as escrituras, aqui ele se limita a mandar o Diabo se calar, ordem que não é obedecida, ou, simplesmente, ouvir em silêncio aquilo que o anjo caído diz. Satanás continua dizendo que o homem "pertence à terra, não pertence ao céu. Esta capa exterior não é o seu verdadeiro ser. O seu verdadeiro ser quer queiras quer não, está comigo”. (BRANDÃO \& PASCOAES, 1984, p. 78). Ironicamente, opera-se uma intensa inversão ao que é dito pela tradição cristã: o diabo é realmente quem está do lado do homem, o verdadeiro humanista, uma vez que este pertence ao mundo, e não o contrário. O cristianismo, por outro lado, traz a humanidade uma esperança de algo que não pode ser realizado "uma vida artificial, que não 
existe”. Enquanto dialogam o Diabo mostra como agem as pessoas a Jesus que resiste às palavras de seu inimigo, que parece representar a voz da razão humana, tal como faz nos evangelhos. E ele termina por concluir, ironicamente: "Ignora o mundo! Um Deus que desconhece o mundo” (BRANDÃO \& PASCOAES, 1984, p. 90).

Ainda no quinto quadro, a ironia maior está na relação dialética entre Deus e o Diabo, que esse apresenta com uma certa dose de sarcasmo:

Se te tento é porque queres. Só tento, porque é da regra e da fórmula. Não há Deus sem tentação. Vamos mais fundo, se queres. Vamos a eterna questão do Bem e do Mal. Quem faz o bem no mundo sou eu, sou eu! Do mal nasce o bem. Devo dizer-te, devo confessar-te, que só tenho conseguido, por mais que faça, praticar o bem. Do egoísmo, do interesse, da vaidade, da guerra, que tem nascido senão a prosperidade? Olha para o mundo transformado, cheio de trabalho ansioso (BRANDÃO \& PASCOAES, 1984, p. 90).

É importante notar que a questão de bem e mal aqui depende do ponto de vista. O Diabo alude a questão do progresso econômico que surge como resultado de alguns dos pecados humanos, atribuídos à ação demoníaca como o egoísmo, a vaidade e a guerra. No entanto, tudo o que ele faz, argumenta, integra uma fórmula dialética de que é preciso existir o mal para que o bem exista, pois um não existe sem o outro e, assim, podemos dizer que Deus só existe porque o Diabo existe:

Escuta, filho! O drama do amor, somos nós dois que o temos conseguido equilibrar. Eu, dum lado, a puxá-los para baixo, para a animalidade; tu do outro, a levá-los para cima, para a espiritualidade. Mas se não fosse a animalidade, já o mundo tinha acabado. E eu quero saber em que te havias de entreter (BRANDÃO \& PASCOAES, 1984, p. 90).

A forma como o Diabo se dirige a Jesus é carregada de pura ironia. Ele age como se estivesse dando conselhos a um jovem que ainda tem muito que aprender sobre a vida. A relação entre quem tem o que aprender e quem tem o que ensinar é semelhante a relação entre Jesus e o Diabo (Pastor) em O Evangelho Segundo Jesus Cristo.

Em síntese, o Jesus apresentado nessa peça corresponde, em parte, ao dos evangelhos, colocado, porém, em um contexto onde a verdade absoluta dos textos bíblicos é relativizada e é nesse sentido que sua figura é questionada. Auerbach, em seu ensaio “A cicatriz de Ulisses”, diz que a pretensão de verdade na Bíblia é tirânica e exclui qualquer pretensão:

O mundo dos relatos das Sagradas Escrituras não se contenta com a pretensão a ser uma realidade historicamente verdadeira - pretende ser o único verdadeiro, destinado ao domínio exclusivo. Qualquer outro cenário, quaisquer outros desfechos ou ordens não têm direito algum a se apresentar independentemente dele, e está escrito que todos eles, a 
história da humanidade, se subordinarão aos seus quadros (AUERBACH, 2004, pp. 11-2).

É essa tirania do texto bíblico, a pretensão à verdade absoluta existente nas Escrituras Sagradas que não se repete no texto aqui analisado. Há a "verdade” evangélica que cerca a pessoa de Jesus, como também há a do Diabo, a dos governantes e assim por diante. A noção de verdade aparece relativizada: não há apenas uma, mas várias verdades individuais que parecem competir entre si, o que possibilita a afirmação do homem, que se revolta contra o que é dito por Jesus: “A verdade é uma mentira”, já que tudo depende de um determinado ponto de vista. 


\section{O Cristo que não quer ser Cristo}

A derradeira tentação de Cristo é, em última instância, a narrativa de um sonho que Jesus tem poucos minutos antes de morrer. Nesse sonho ele experimenta sensações que não pode ter em vida por ter sido obrigado por Deus a cumprir seu papel como messias. Em $A$ Última Tentação de Cristo, Jesus vê seu amor por Maria Madalena finalmente se consumar fisicamente. Ela morre e ele, então, une-se às irmãs de Lázaro, Marta e Maria, e tem filhos com elas, consumando um desejo que o persegue por quase todo o romance: casar como um homem comum e constituir uma família. Podemos perceber que o sonho por si só já destoa da versão bíblica que apresenta Jesus como um ser acima das paixões humanas, mais preocupado com o reino dos céus do que com os prazeres terrenos. No entanto, a tendência de humanizar essa personagem não se limita apenas ao sonho na cruz, mas perpassa todo o romance. Desde de o princípio a figura central dessa narrativa oscila entre o desejo de viver como um homem e a obrigação de cumprir seu papel como o messias profetizado, mesmo assim, ao termo da narrativa tudo acontece como deveria ser: Jesus morre na cruz. Em outras palavras, o romance de Kazantzakis nos apresenta um ser distinto da versão original dada pelos evangelhos, pois esse é apresentado com toda a força de sua natureza humana em detrimento da divina, que surge como uma imposição de Deus. Assim, o filho de Maria desce o pedestal e quem o tenta não é exatamente um anjo caído, mas a própria natureza da vida dos homens, seus próprios desejos carnais, o papel do Diabo na tradição cristã é, por muitas vezes atribuído a Deus, como veremos mais adiante.

A luta inglória do Jesus de Kazantzakis contra o seu destino é o motivo que rege essa narrativa, algo que, de certo modo, lembra o Evangelho Segundo Jesus Cristo, de Saramago. Seu desejo de viver como um homem é o motivo da culpa que o faz sofrer, pois ele se considera responsável pelo destino dos outros, um fardo enorme, imposto por Deus, que ele não quer para si. O mundo dos homens é o que a personagem almeja, numa inversão patente do que era anunciado pelo Cristo bíblico:

É verdade, tenho medo... Você quer que eu me levante e fale, certo? Mas o que eu posso dizer? Como vou poder dizer alguma coisa? Não, não posso, já disse. Sou analfabeto!... O que você disse?... O reino dos céus?... Não ligo nem um pouco para o reino dos céus. Gosto da terra. Quero me casar, já disse. Quero Madalena, mesmo que ela seja uma prostituta. É por minha culpa que ela é assim. Minha culpa, e eu vou salvá-la. A ela! Não a terra! Nem ao reino desse mundo. É a Madalena que desejo salvar. Para mim, isso basta... E fale mais baixo, não consigo entender o que diz (KAZANTZAKIS, 1988, p. 33). 
O trecho acima se trata de uma conversa de Jesus com Deus, ou mais precisamente um monólogo, pois quase nunca ouvimos a voz divina nessa narrativa, embora sua presença seja sensível principalmente quando é preciso garantir que Cristo seja crucificado. As diferenças em relação ao texto bíblico são evidentes. A personagem mostra revolta perante a sua situação e medo do que lhe pode acontecer. Jesus oscila entre o ser egoísta, cujo principal objetivo é se casar com Maria Madalena e estabelecer uma vida simples como um homem e o sentimento de culpa por não desejar cumprir o seu destino. Não é mais aquele que simplesmente diz "Pai, seja feita a tua vontade!”, mas alguém que questiona abertamente essa determinação. Seu interesse é a terra e a vida dos homens, não algo que está além dessa vida, um paraíso celeste como o prometido pela tradição cristã.

Nesse sentido, o papel de Maria de Magdala é de suma importância na narrativa, uma vez que Jesus é perdidamente apaixonado por ela, e luta, durante todo o romance, para afastar de si os desejos sexuais que sente por Maria e seguir o seu destino como Filho de Deus. A relação entre os dois remonta a infância de ambos:

\begin{abstract}
Madalena saltou de súbito de dentro da multidão e pregou os olhos no filho de Maria, que ainda vinha subindo. Seu coração enchia-se de tristeza quando ela recordava os momentos em que, ainda pequenos, brincavam juntos: ele com três, ela com quatro anos. Que alegria profunda e inefável haviam experimentado então! Que doçura indescritível! Pela primeira vez, os dois haviam percebido o fato ao mesmo tempo nítido e obscuro de um ser homem e o outro, mulher. Dois corpos que pareciam outrora ter sido um, e que algum Deus cruel separara. Agora as partes encontravam-se novamente e procuravam juntar-se, reunir-se. Quanto mais cresciam, mais claro percebiam o milagre de um ser homem e o outro, mulher. E olhavam-se com um pavor mútuo, como dois animais selvagens esperando que a fome aumentasse e que chegasse a hora em que fluiriam um para dentro do outro, unindo o que Deus separara. Foi então que, numa noite festiva em Caná, quando o amado lhe estendeu a mão para lhe dar a rosa e firmar o noivado, o Deus impiedoso descera sobre eles, separando-os mais uma vez. E desde então... (KAZANTZAKIS, 1998, p. 46).
\end{abstract}

Maria é prima de Jesus. E a lembrança mais recorrente para essas duas personagens no decorrer do romance é esse episódio da infância. Desde então os dois desejaram-se mutuamente, porém, o Deus impiedoso tratou de os separar. Essa intervenção divina aparece como uma inversão patente das palavras do evangelho: “o que Deus uniu o homem não separe” (Mc 10, 9). No entanto, no romance homem e mulher seguem no caminho natural que seria o da união entre eles, mas Deus trata de separá-los mediante seus próprios interesses.

O Jesus de Kazantzakis sabe de antemão que o seu destino é morrer na cruz como o 
messias. Sua vida inteira flui no sentido de seu martírio como filho de Deus, mas como homem isso resulta em um sofrimento antecipado, como o de alguém que está no corredor da morte e tem data marcada para a sua execução, de modo que não pode fazer planos como os demais homens. Tal é o ambiente em que se desenvolve o Jesus de Kazantzakis. O Cristo bíblico tem conhecimento de seu destino, no entanto ele se comporta como um ser divino acima dos demais homens e aí está a sua força, o motivo pelo qual ele vai para o matadouro sem sentir medo, pois tudo no seu percurso terreno encaminha-se, perfeitamente, no sentido do cumprimento das profecias e nem lhe passa pela cabeça questionar esse fato. Por outro lado, a personagem do romance não deseja o sacrifício, pois está no mesmo nível dos demais homens e seu desejo é viver como eles, eis o princípio da humanização de Jesus realizada no romance de Kazantzakis. Não se nega aqui o a priori de seu destino e nem se exclui totalmente sua origem divina, no entanto se intensifica sua natureza humana. A humanidade para o Jesus bíblico significa apenas o verbo encarnado: "E o verbo se fez carne, e habitou entre nós, e nós vimos a sua glória, glória que ele tem junto ao Pai como Filho único, cheio de graça e de verdade” (Jo. 1, 14). Para o Jesus do romance, humanizar-se vai além de ser um espírito encarnado, pois não se limita apenas às dores físicas, mas as dores da alma, aos sentimentos puramente humanos, como o amor, o ódio, o medo, que parecem estranhos ao Cristo das escrituras sagradas. Desse modo, no romance de Kazantzakis o termo “tentação” é levado até as suas últimas conseqüências e em muitas vezes o tentado só não sucumbe prazerosamente, porque Deus, que lhe impõe seu destino, impede que isso aconteça, o que ocorre em pelo menos dois momentos no deserto. No primeiro, a serpente lhe oferece Madalena, um dos seus mais íntimos desejos e no momento em que Jesus vai aceitar, sente a presença de Deus a dizer-lhe que não faça isso:

No instante em que ia abrir a boca para concordar, sentiu que alguém acima dele o olhava. Apavorado, ergueu a cabeça e viu dois olhos no ar, apenas dois olhos, negros como a noite e duas sobrancelhas brancas que se moviam para indicar-lhe que dissesse não (KAZANTZAKIS, 1988, p. 264).

Outro fator interessante a se notar nesse romance é o desenvolvimento da escrita do evangelho por Mateus, um dos discípulos de Jesus. O papel de Mateus é interessante dentro dessa estrutura narrativa, uma vez que ele representa a escrita do evangelho bíblico que leva o seu nome. Esse, no romance, trata-se de um texto em formação que contrasta com a própria realidade da narrativa. Parece que o texto principal (o romance) ao ficar em contradição com 
o texto aludido (o Evangelho segundo Mateus) estabelece com ele uma relação crítica. O que Mateus escreve não corresponde exatamente ao que ocorre na narrativa, são criações induzidas por um “anjo” para que os acontecimentos correspondam às antigas profecias judaicas. Há de certo modo um questionamento das verdades estabelecidas, onde existe uma verdade divina que é ininteligível para o homem, nem o próprio Jesus a compreende. Considerá-la como tal, uma vez que ela não corresponde aos fatos narrados é uma ironia que perpassa por todo a narrativa:

Eu digo uma coisa, você escreve outra, e quem lê entende ainda outra. Quando falo da cruz, da morte, do reino dos céus, o que vocês entendem? Cada um atribui seus próprios sofrimentos, desejos e interesses a essas palavras sagradas, assim o que eu disse desaparece; meu espírito fica perdido. Não consigo agüentar mais! (KAZANTZAKIS, 1988, p. 426).

O Todo-poderoso, que hora e outra manipula as personagens para que ajam conforme a sua vontade, caracteriza-se como um ser cruel e impiedoso, de modo que, a todo o momento, ele impede que as personagens sigam o curso normal de suas vidas. Jesus, como vimos acima, é forçado por seu pai divino a cumprir o seu papel de messias. E assim os atos de Deus são vistos como sinônimo de sofrimento por várias das personagens: "Deus é o grande inimigo, pensava, sim, Deus. Ele nunca deixa de se intrometer. É perverso, ciumento. Não quer que ninguém seja feliz...” (KAZANTZAKIS, 1988, p. 99). E, assim, a palavra “inimigo", comumente usada para designar o Diabo, que na tradição cristã é o supremo representante do mal que assola a humanidade, passa a designar Deus, que é a própria razão do sofrimento das personagens que se revoltam inutilmente contra ele em vários momentos da narrativa.

Em uma das ofertas que a serpente faz a Jesus, oferecendo-lhe os reinos do Mundo Antigo, Babilônia, Alexandria e Roma, como prêmio para que este aceite de vez a sua condição humana, Deus interfere para que Cristo não aceite a oferta a que estava sensivelmente inclinado a aceitar. Para isso, Deus, ameaçadoramente, faz com que as imagens de glória do poder terreno virem cinzas diante dos olhos de Jesus e lhe diz sarcasticamente: "São estes, infeliz, os reinos desse mundo que você dispõe a conquistar. E aqueles são meus três anjos dourados: a Lepra, a Loucura e a Chama. Chegou o dia do Senhor, o meu dia, o meu!" (KAZANTZAKIS, 1988, p. 269).

O Deus que se visualiza nessas palavras é semelhante ao que será desenvolvido mais tarde em O Evangelho Segundo Jesus Cristo. O Deus de Kazantzakis é o ser cruel do Antigo 
Testamento, que pouco se importa com o sofrimento dos homens, e mais do que isso: é ele mesmo que os faz sofrer. Ele é o responsável pelo sofrimento de Maria, a mãe de Jesus, a quem negou os poucos prazeres que uma mulher poderia ter na vida como conhecer um homem e procriar. Dessa forma, a Maria conformada e bem-aventurada por ter sido escolhida para ser a mãe do filho de Deus é, no romance de Kazantzakis, uma mulher sofredora e desencantada com a vida. Pode-se dizer que ela é uma das primeiras vítimas da sede de poder do Deus cristão, pois lhe foram negados todos os prazeres terrenos reservados a uma mulher na sua condição: não soube o que era ser jovem, não conheceu homem, é mãe sem ter filhos. Essa imagem do Deus cruel vai se repetindo na fala e no pensamento das personagens. "Deus sem compaixão” é a fala de Pedro quando vê Jesus carregando a cruz em que se crucificaria um zelota.

Mas é interessante notar que, no romance de Kazantzakis, a imagem de Deus muitas vezes se confunde com a do próprio homem. É como se o divino, de modo contrário à idéia exposta por Feuerbach, fosse reflexo do lado cruel da própria humanidade:

Grandes coisas acontecem quando Deus se mistura com o homem. Sem o homem, deus não teria mente nesta Terra que refletisse de forma clara sobre suas criaturas, e que analisasse, temerosa porém com ousadia, sua sábia onipotência. Não teria nesta Terra um coração que se preocupasse com o problema dos outros e que lutasse para criar virtudes ou cuidados que Deus não quis, esqueceu-se ou teve medo de moldar. Ele, contudo, insuflou no homem o sopro da vida, para que este tivesse o poder e a audácia para prosseguir com a criação. (KAZANTZAKIS, 1988, p. 288).

O tom irônico do trecho acima, no que diz respeito a Deus, reforça a impressão de que sua existência é moldada a partir de uma projeção que o homem faz de si mesmo. Deus parece não existir nesse romance, como uma entidade, tal como a que aparece em $O$ Evangelho Segundo Jesus Cristo, por exemplo. Em nenhum momento da narrativa ele surge e fala com alguma personagem diretamente e quando isso acontece, como no deserto, por exemplo, temse a impressão de que a personagem pode estar delirando. Enfim, presença se manifesta através de sonhos ou delírios que mais parecem manifestações de loucura.

Em suma, o Jesus de Kazantzakis luta, embora sem nenhum sucesso, para afirmar sua natureza humana perante Deus. Ele até mesmo se insurge contra o seu Senhor, construindo cruzes para sacrificar seus profetas, não poderia haver pecado maior é o que pensa Jesus. No entanto, o Cristo desse romance se conforma e caminha em direção ao seu destino, mesmo não sabendo ao certo o que isso desencadeará. No entanto, humanidade é intensificada no 
romance, através de sentimentos como amor, ódio, medo e dúvida. 


\section{Deus, a maldição da humanidade}

\subsection{Os Atos dos Apóstolos ao avesso}

A narrativa de Barrabás se inicia remetendo-nos a arquiconhecida cena da crucificação. São citadas as personagens já conhecidas do cenário, sendo elas Maria, a mãe de Jesus, Maria Madalena, Verônica, Simão Cireneu e José de Arimatéia. No entanto, em sua parte inferior o narrador nos apresenta Barrabás, uma figura estranha ao que a tradição cristã conta e ilustra a respeito da cena da crucificação de Cristo:

\footnotetext{
Um pouco afastado dos outros, porém mais abaixo da encosta, um homem observava constantemente aquele que estava pregado na cruz, lá no alto, acompanhando sua agonia do começo ao fim. Chamava-se Barrabás. E é sobre ele que falará este livro" (LARGERKVIST, 1966, p. 69).
}

Podemos notar pelo início que a vida desse herói será relacionada com as repercussões da morte de Jesus e o desenvolvimento do cristianismo em seus primórdios, poderíamos pensar, assim, em uma espécie de Atos dos Apóstolos ao avesso. Desse modo, o início da história cristã é mostrada pelos olhos de uma personagem ínfima na narrativa dos evangelhos. O único momento na Bíblia em que encontramos seu nome é no momento da decisão final de Pilatos, que dá ao povo judeu a oportunidade de escolher quem deveria ser crucificado, se Jesus ou o bandido de nome Barrabás, o desfecho dessa história todos nós já sabemos: Cristo é o escolhido para o martírio e o bandido ganha uma nova chance de viver. E é essa ínfima figura dos evangelhos que Largerkvist transforma em protagonista de sua novela, que tem como tema central o cristianismo nascente. Além dessa obra do escritor sueco, Barrabás aparece como personagem em Memórias de Judas e em A Última Tentação de Cristo. No primeiro caso, essa personagem pode ser caracterizada como uma pessoa vil e mesquinha, capaz de prostituir a própria sobrinha. Na narrativa de Gattina, Barrabás é tio de Jesus, com quem mantém uma relação nada amistosa. No romance de Kazantzakis, a personagem que leva o nome de Barrabás é um zelota, revolucionário subordinado a Judas Iscariotes e que se não fosse por seu superior teria matado Jesus antes mesmo da crucificação. A personagem central dessa novela de Lagerkvist pouco tem a ver com essas duas versões dessa figura ínfima na história de Jesus, uma vez que ele é apresentado como uma figura pouco conhecida, um reles bandido que tirou a sorte grande no momento em que deveria ser condenado à morte: 
ganhou a liberdade no lugar de um inocente.

No decorrer da narrativa de Barrabóas, os encontros entre a personagem principal e os discípulos do mestre galileu e a vaga lembrança do “Amai-vos uns aos outros”, cerne da pregação de Cristo, citado pelo quarto evangelista, vão paulatinamente nos mostrando como o destino do herói da narrativa está inexoravelmente ligado ao destino trágico de Jesus, segundo Linder:

\begin{abstract}
A apresentação de Barrabás como "herói” da novela define aqui o talento inventivo do autor. Foi a ele que libertaram no lugar de Jesus, por intervenção do próprio Cristo. Mas, concomitantemente, vemo-lo orientado para o struggle for life, tão inacessível ao idealismo exaltado do Sermão da Montanha quanto à mística contida no relato da Paixão ou à crença nos milagres. Diante do túmulo vazio constata que, devido a um encadeamento de circunstâncias, seu destino está inexoravelmente entrelaçado ao do Nazareno crucificado, de cuja presença jamais virá a libertar-se. Barrabás é um crente despido de fé, um discípulo sem a menor aptidão para seguir e imitar (LINDER, 1966, p. 54).
\end{abstract}

Uma vez livre o herói da narrativa é recebido por seus amigos que o vêem como um homem de muita sorte, pois escapou de uma condenação que lhes parecia inevitável: “Imaginem, ter ele saído da prisão, ter sido perdoado! Que grande sorte, crucificaram outro em seu lugar” (LARGERKVIST, 1966, p. 78). É interessante notar que Jesus não parece ser alguém que goze de popularidade entre o grupo ao qual pertence Barrabás, pois eles se referem a ele como o outro que foi condenado no lugar do novo homem que está ali diante deles, um homem ressuscitado: "Ele morrera, pois e nascera de novo, o que não era o mesmo que ser vivo como os outros” (LARGERKVIST, 1966, p. 78). Desse modo a idéia de ressurreição parece tomar um outro significado, pois aqui ela não quer dizer o milagre supremo de um Deus que pode dar a vida, mas apenas se refere a um homem que escapou de uma morte dada como certa. Desmitifica-se, nesse relato, o mito da ressurreição, que não acontecerá de fato como veremos mais adiante.

A presente narrativa se desenvolve depois da crucificação e dá-se no período inicial da religião cristã. Nos primeiros capítulos encontramos os discípulos e outras pessoas expondo as mais diversas opiniões sobre Jesus, quando esse ainda vivia. Fala-se sobre os milagres e as profecias do rabi de Nazaré, que são colocadas ao lado dos feitos semelhantes realizados por outros rabinos da mesma época. Como se pode perceber nada do que o filho de Maria fazia se caracterizava para as testemunhas como uma novidade, eram fatos comuns. Convém lembrar que tal perspectiva está presente em A Vida de Jesus, de Renan, para quem Jesus foi uma espécie de reformador religioso que não aceitava o papel de taumaturgo nem de exorcista, que 
lhe foi imposto pelo público que lhe acompanhava ${ }^{22}$. Dentro dessa perspectiva podemos situar também Memórias de Judas, de Gattina, em que Jesus mais se parece com um fanático religioso e seus milagres, como já vimos, são frutos de sua habilidade em realizar truques; e $A$ Relíquia, em que Cristo se assemelha a um religioso muito devotado, que nada tem de especial. Na novela de Lagerkvist, o que realmente causava estranheza aos companheiros de Barrabás era o convívio de Jesus com os pobres:

\begin{abstract}
Uma das mulheres pôs-se a falar do homem que tinha sido crucificado em lugar de Barrabás. Ela o tinha visto uma vez, mas só de passagem, e lhe tinham assegurado que se tratava de um Rabi muito versado nas escrituras e que percorria o país fazendo profecias e milagres. Isso não era nada de mais, tantos outros o faziam também; certamente havia outro motivo pelo qual o haviam sacrificado. Era ele um homem magro, disso ela ainda se lembrava. Outra disse que nunca o tinha visto, mas ouvira falar de suas profecias; ele vaticinava que o templo iria desmoronar-se, que Jerusalém seria destruída por um cataclismo, e que em seguida, as chamas consumiriam o céu e a terra; enfim, coisas absurdas. Não era, pois, de estranhar que o tivessem crucificado. A terceira acrescentou que ele vivia mais com os pobres tendo-lhes prometido que entrariam no reino de Deus; até às prostitutas ele o prometera. Todos riram muito e acharam que não seria nada de mau, se fosse verdade (LARGERKVIST, 1966, p. 79).
\end{abstract}

Eis o modo como a figura de Jesus vai sendo construída no decorrer da novela: através do testemunho de outros. Sabemos que Barrabás mal o conhecia enquanto estava vivo. O caso não é diferente com as três mulheres acima. Uma delas, que o havia visto uma vez de passagem, comenta que ele realizava profecias e milagres, mas que não havia novidade nisso, uma vez que outros faziam o mesmo. Geza Vermes e Crossan se referem à existência de exorcistas e taumaturgos na época de Jesus. Nessa novela, tais qualidades, tão caras aos evangelhos, são banalizadas, carecem de novidade para o povo que as testemunha ou ouve falar sobre elas. Desse modo, a primeira mulher considera que não pode ser esse o motivo pelo qual Jesus foi sacrificado. A segunda mulher diz que nunca o tinha visto, mas ouviu falar de suas profecias, de caráter escatológico, e que talvez fosse esse o motivo pelo qual o crucificaram. A pregação do nazareno é vista também por outros autores como motivo para o condenarem, pois contrariava os dirigentes religiosos da época. Segundo Crossan,

É bem possível que Jesus tenha ido a Jerusalém uma única vez e que o igualitarismo

\footnotetext{
22 “Num sentido geral, é lícito dizer que Jesus não foi taumaturgo, nem exorcista, senão contra a sua vontade. O milagre é de ordinário mais obra do público do que daquele a quem se atribui. Jesus recusou obstinadamente fazer prodígios que a multidão criou para ele; o maior milagre seria não fazer nenhum; nunca as leis da história da psicologia teriam sofrido tão forte revogação. Os milagres de Jesus foram uma violência que lhe fez o seu século, uma concessão que lhe arrancou a necessidade do momento. Por isso o exorcista e o taumaturgo caíram; mas o reformador religioso vivera eternamente” (RENAN, 1926, p. 216-7).
} 
espiritual e econômico que pregava na Galiléia tenha explodido numa onda de indignação diante do Templo, símbolo de tudo que era anti-igualitário, patronal e até mesmo opressivo, tanto no nível religioso, quanto no político (CROSSAN, 1994, p. 398).

A imagem de Jesus como aquele que fica do lado dos oprimidos é o que aparece como novidade e até encanta a terceira mulher. A promessa do reino de Deus a todos os pobres sem distinção é o fato novo em questão e que entra no âmbito desse igualitarismo espiritual e econômico ao qual Crossan se refere acima. E, ironicamente, as personagens comentam que seria bom se fosse verdade a promessa feita aos pobres, incluindo as prostitutas.

Como podemos perceber, após receber uma segunda chance, Barrabás se vê envolvido com o legado deixado pelo homem que morreu em seu lugar, interessa-lhe, sobretudo, saber quem era tal homem. Chega mesmo a se encontrar com seus discípulos e, em uma conversa com Pedro, discute a veracidade de ser Jesus o messias profetizado no Antigo Testamento. Nesse diálogo, o apóstolo aparece como o homem ingênuo, ao passo que Barrabás é a voz da razão:

\footnotetext{
- Sim, deve ter sido um homem extraordinário, se o que dizes é verdade. No entanto, o fato de ter sido crucificado não prova que sua força não era, afinal, tão grande assim?

- Não... não é isso. Eu também pensei assim a princípio e é justamente o que me aflige - ter acreditado em semelhante coisa, ainda que fosse um só momento. Mas agora creio que compreendi o sentido de sua morte ignominiosa, agora que refleti um pouco e falei com os outros mais versados nas escrituras. Vês, por nossa causa, ele, inocente, teve de sofrer tudo o que sofreu, até mesmo descer ao reino das sombras. Mas ele voltará para dar provas de seu infinito poder. Ele ressuscitará de entre os mortos! Estamos absolutamente certos disso. (...)

O homem era tão ingênuo que Barrabás teve vontade de rir. (...) (LARGERKVIST, 1966, p. 91; 93).
}

Barrabás questiona os poderes atribuídos a Jesus uma vez que esse se deixou crucificar. No entanto, Pedro, que confessa que a princípio teve dúvidas sobre a capacidade de seu mestre, reafirma crer nele depois de ter conversado com pessoas mais versadas sobre a escritura. Em todo o diálogo entre essas personagens há um embate entre um crente e um descrente da existência sobrenatural do filho de Maria. Barrabás até admite que ele possa ter sido um homem extraordinário, mas com reservas sobre o poder que a ele é atribuído. Por outro lado, seu interlocutor é apresentado como um homem muito ingênuo, que parece capaz de acreditar em qualquer coisa que lhe disserem. É difícil acreditar que o crucificado possa ser alguém de valor se não lhe atribuir uma natureza divina, é por crer nisso que Pedro defende seu mestre, acreditando que a crucificação foi predeterminada e que ao final de três dias, Jesus 
ressuscitará, fato de que não temos notícia nessa narrativa, pois não se volta ao assunto. Ao contrário do apóstolo, Barrabás apresenta dúvidas compreensíveis, uma vez que não compartilha da mesma fé que seu interlocutor.

Durante boa parte da narrativa, em seus encontros com os novos cristãos, Barrabás se põe a questionar as promessas relacionadas à nova religião. A pergunta central e mais importante poderia ser a seguinte: Se é prometida a salvação, por que tanto sofrimento? E tal indagação acentua-se principalmente depois da morte da mulher, para quem a doutrina de Jesus se resumia nas seguintes palavras: “Amai-vos uns aos outros”. Nesse episódio, Barrabás questiona o fato de atribuir-se o título de Salvador ao crucificado: "Seria o verdadeiro Messias? O redentor do mundo? O salvador de toda a humanidade? Por que deixara que a apedrejassem por sua causa? Se era o salvador, por que não a tinha salvo?” (LARGERKVIST, 1966, p. 137). Toda a dúvida reside no fato inelutável de que crer no suposto salvador pode significar sentença de morte, como no caso do próprio fundador da religião, da mulher apedrejada e ao termo da narrativa, da morte do próprio Barrabás. E essas mortes não fazem o menor sentido a partir do momento que não se conhece nenhuma vida além da terrena. Em Muerte de Ahasverus, ficamos sabendo que o verdadeiro responsável por todo esse sofrimento é Deus e que Jesus não passa também de uma vítima, falaremos disso mais adiante. É factível, então, que os motivos que regem essa narrativa são humanitários, pois se voltam contra o sofrimento causado pela fé religiosa: a mulher foi assassinada unicamente porque acreditava na doutrina de Cristo. Em O Evangelho Segundo Jesus Cristo, de José Saramago, essa crítica será ainda mais direta e contundente, principalmente no encontro entre Jesus, Deus e o Diabo, no meio do Mar da Galiléia. Ao partir do princípio de que o homem de quem falam os cristãos é mesmo um deus, Barrabás conclui, ironicamente, que esse homem gosta do sofrimento, do seu e do alheio:

\footnotetext{
Ele o poderia muito bem ter feito, se o quisesse. Mas gostava do sofrimento, do próprio e do alheio. E queria que dessem testemunho dele. "Agora dei testemunho de ti, como me mandaste fazer..." "Ressuscitado do reino dos mortos para dar testemunho de ti..."

Não, Barrabás não gostava nada daquele homem crucificado. Odiava-o, até. Ele causara a morte da mulher. Exigira seu sacrifício e vigiara para que ela não escapasse. O crucificado estivera presente lá embaixo no fosso. Ela o vira e fora ao seu encontro estendendo os braços, suplicando para que a socorresse; agarra-se a orla de seu manto e ele não movera um dedo para ajudá-la. E aquele seria o filho de Deus! O filho de Deus, cheio de amor... O salvador da humanidade! (LARGERKVIST, 1966, p. 137-8).
}

Outro dado interessante no que diz respeito à mulher apedrejada é a possível relação 
desse episódio com a morte de Estevão por apedrejamento em Atos dos Apóstolos 7, 55-60²3. Considerado o primeiro mártir do Cristianismo, Estevão viu Jesus no momento da morte, segundo a narrativa bíblica, do mesmo modo como Barrabás deduz que a mulher viu Cristo no momento em que morria lapidada. No entanto, ao contrário do mártir bíblico que pregava contra os costumes judaicos, ela prometia a volta de Cristo que curaria todos os doentes que moravam nas portas da cidade porque não podiam viver nela com os sãos. Como sua promessa demorava a ser cumprida, os doentes se revoltaram contra ela e alguém a denunciou na cidade como a autora de uma blasfêmia, o que resultou em sua condenação à morte. Segundo Linder, o sublime atinge seu ponto mais alto nessa novela de Lagerkvist, quando Barrabás transporta o corpo sem vida dessa mulher de lábios leporinos, lapidada unicamente por ter acreditado na mensagem cristã:

O sublime atinge, nesse relato, seu ponto culminante quando o ladrão Barrabás, sem saber ele mesmo porquê, transporta o corpo de uma mulher, que foi apedrejada até a morte pelo crime de ter um lábio leporino, através do deserto, para sepultá-lo; a ação é um eco confuso e desesperado da singular exortação que certa vez ouviu, a propósito daquele defeito físico: “Amai-vos uns aos outros” (LINDER, 1966, p. 54-5).

Depois desse episódio Barrabás não é mais o mesmo, tanto que desaparece da presença de seus amigos e anos mais tarde reaparece como escravo na Ilha do Chipre. É aí que conhece Sahak, seu companheiro de suplícios, conhecedor da história de Jesus que ao saber que Barrabás conhecera o Rabi, começa a lhe fazer vários tipos de perguntas sobre a vida daquele que ele considerava um Deus. Sahak era um cristão que, assim como a mulher de lábios leporinos, considera que o poder de Deus baseia-se no amor. Da mesma forma que a mulher, através da fé nas palavras de Cristo, o escravo Sahak tinha a esperança de um dia viver em um mundo mais igualitário, onde não houvesse a opressão de que era vítima. Ironicamente, o amor é para essas personagens o âmago da mesma religião pela qual padecem com o ódio e o desprezo, como se já não bastasse a sua condição de oprimidos, de marginalizados da sociedade. O fim de Sahak, que se recusa a negar sua religião, é a morte como escravo, tal como a da mulher e de várias outras pessoas, que morreram em nome do

\footnotetext{
23 “Estevão, porém, repleto do Espírito Santo, fitou os olhos no céu e viu a glória de Deus, e Jesus, de pé, à direita de Deus. E disse: 'Eu vejo os céus abertos, e o Filho do Homem, de pé, à direita de Deus'. Eles, porém, dando gritos, taparam os ouvidos e precipitaram à uma sobre ele. E arrastando-o para fora da cidade, começaram a apedrejá-lo. As testemunhas depuseram seus mantos aos pés de um jovem chamado Saulo. E apedrejaram a Estevão, enquanto este invocava e dizia: 'Senhor Jesus, recebe meu espírito'. Depois, caindo de joelhos, gritou em voz alta: "Senhor não lhes leve em conta este pecado”. E, dizendo isto, adormeceu” (At 7, 55-60).
} 
amor de Deus, tema que está presente também em O Evangelho Segundo Jesus Cristo.

Pela segunda vez na sua vida Barrabás assiste à crucificação de alguém como um homem que acabou de ser liberto dessa mesma morte ignominiosa. A crucificação de Sahak é relacionada na narrativa a própria morte de Cristo:

\begin{abstract}
Dentro de pouco o peito magro cessou de arquejar e era fácil compreender que Sahak estava morto. Não houve trevas sobre a face da terra nem nada de prodigioso ocorreu quando ele, em silêncio e sem que ninguém soubesse, entregou seu espírito. Os que estavam encarregados de o vigiar nada perceberam; distraiam-se jogando dados, exatamente como tinham feito outros no mesmo mister, certa vez, havia já muito tempo... Desta vez não se alvoroçaram nem se assustaram por ter morrido um homem na cruz. Não deram mesmo a menor atenção ao fato (LAGERKVIST, 1966, p. 181).
\end{abstract}

Como vemos, a alusão à crucificação de Cristo é evidente. O narrador se refere à atmosfera milagrosa que caracteriza o cenário da morte de Jesus na narrativa bíblica, quando o filho de Deus entrega o seu espírito e afirma que nada disso acontece na morte de Sahak, o que assemelha as duas mortes é o jogo de dados dos soldados que estavam a vigiar o condenado, que estão totalmente indiferentes à morte do miserável. Barrabás, escondido atrás de um arbusto é o único a notar e sofrer com o suplício de Sahak: “Assim aconteceu quando crucificaram Sahak, e Barrabás, o libertado assistiu à sua morte” (LAGERKVIST, 1966, p. 182).

Após o episódio citado acima, Barrabás ganha a simpatia do governador da província por ter, ao contrário de Sahak, renegado o nome de Cristo que estava inscrito em sua placa de escravo. Assim, quando o seu senhor abandona a ilha para ir morar em Roma, o herói da narrativa é levado juntamente com os pertences do governador. Na capital do Império, ele procura se manter por algum tempo indiferente as notícias sobre os cristãos, mas num certo dia resolve se aventurar nas catacumbas, onde eles se reuniam para evitar a perseguição dos romanos que os odiavam. Não os consegue encontrar, perde-se nas galerias da catacumba em que foi procurá-los e de repente sente como se estivesse já no mundo dos mortos: “O reino da morte! Estava no reino da morte! Preso, fechado, dentro do reino da morte...” (LAGERKVIST, 1966, p. 189). Quando consegue sair da catacumba em que se perdera ele se encontra nas ruas de Roma completamente abalado e se sentindo só até que percebe vestígios de incêndio e gritos que acusam os cristãos por isso. Alucinado, Barrabás acaba se convertendo ao cristianismo, de modo um tanto enviesado, contrário ao "amai-vos uns aos outros”, que ele ouvira até aqui. Ele julga que o incêndio de Roma é obra do próprio Cristo 
que voltara para redimir a humanidade e incendiar o mundo:

Não ia trair o seu Senhor, quando este mais precisava dele, quando a hora tinha chegado, a hora grandiosa em que tudo devia perecer... O incêndio propagava-se, as labaredas se alastravam. Até onde a vista alcançava, tudo era um vasto oceano de chamas! O mundo inteiro desmoronava, ardia numa fogueira imensa!

Vêde, o seu reino aí está! Seu reino chegou! (LAGERKVIST, 1966, p. 193).

É interessante notar que o seu primeiro e único ato como cristão é o uso da violência. Ele inicia o incêndio de Roma ${ }^{24}$, com a justificativa de que queria ajudar seu Salvador a destruir esse mundo, Ele se converte exatamente pelo caminho contrário dos outros cristãos que conhecera, todos pobres como ele, alucinado, ele julga que é o fim do mundo e que deve contribuir para que isso aconteça. Seu ato custou a morte de muitos cristãos inocentes:

Como poderiam os seguidores do Mestre tornar-se culpados do incêndio, de atear fogo a Roma? Como podia haver quem acreditasse em semelhante coisa? Seu Mestre incendiava almas, não as cidades. Ele era o salvador e o Deus do mundo, não um malfeitor (LARGERKVIST, 1966, p. 197).

Como vemos, a morte de inocentes é mais uma vez causada pela crença religiosa. E aquele que se apresenta como o salvador é, ironicamente, o motivo da perdição de muitos, que na maioria dos casos já eram excluídos da sociedade em que viviam. Na prisão, Barrabás reencontra com Pedro, que o identifica para os outros presos como aquele que fora libertado no lugar de Jesus. Bastou isso para que ele ficasse só novamente, como passara boa parte da sua vida de libertado. Assim, no final da novela, o herói da narrativa que passou sua "segunda vida” as voltas com o legado de Jesus, viveu poucos momentos como um cristão, voltando novamente as suas indagações sobre as palavras de Jesus e sobre a fé daqueles que criam no que havia dito o nazareno, que com estavam ali com ele presos e condenados à morte. A vida eterna em que acreditavam não existia para Barrabás e sim a escuridão e foi para ela que ele

\footnotetext{
${ }^{24}$ Renan, em $O$ Anti-Cristo, considera que o incêndio de Roma foi perpetrado por ordem de Nero: "O que confirmou as suspeitas foi que, após o incêndio, Nero, sob o pretexto de limpar as ruínas à sua custa, para deixar o terreno livre aos proprietários, se encarregou de roubar as demolições, não obstante não ser permitido a ninguém aproximar-se delas. E ainda mais quando o viram aproveitar-se das ruínas da pátria e erguer-se no local da antiga residência provisória, engrandecido pelo espaço que o incêndio lhe franqueara, o novo palácio de Nero, essa "Casa d'ouro" que era há muito objetivo de sua imaginação em delírio. Imaginou-se que ele quisera assim preparar os terrenos para esse novo palácio, justificar a reconstrução que projetava há tanto tempo, buscar o dinheiro necessário apropriando-se dos despojos do incêndio, satisfazer enfim sua louca vaidade, que lhe fazia desejar reedificar Roma para que ela datasse dele e ele pudesse dar seu nome” (RENAN, 1930, p. 103). Como podemos ver, na visão do escritor francês, o incêndio não passa de um momento de delírio do Imperador romano, em nenhum momento ele comenta as acusações feitas aos cristãos pelo incêndio da capital do Império.
} 
entregou o seu espírito ao morrer: “A ti entrego a minha alma” (LARGERKVIST, 1966, p. 202). A vida atormentada e sem sentido do ressuscitado Barrabás parece ter eco nas palavras de Maria de Magdala em O Evangelho Segundo Jesus Cristo, que impediram que Jesus ressuscitasse Lázaro: "Ninguém na vida teve tantos pecados que mereça morrer duas vezes” (SARAMAGO, 2001, p. 428).

\subsection{Cristo, um desgraçado como nós}

Em Muerte de Ahasverus, encontramos um homem amaldiçoado a vagar pelo mundo por se ter negado a ajudar Jesus em seu caminho em direção ao martírio na cruz. Trata-se aqui de uma exploração do mito do judeu errante. A narrativa, que se refere a algum momento da Idade Média, começa em uma estalagem, onde estão alojados peregrinos que têm como destino a Terra Santa.

Essa novela pode ser dividida em três partes. A primeira se refere às conversas na estalagem entre Ahasverus, Diana e Tobias. Esse relata a Ahasverus o motivo pelo qual está ali, uma vez que ele não se considera como um peregrino. A segunda parte corresponde à caminhada dos três em direção ao porto de onde os romeiros partem para a Terra Santa. Nesse momento da narrativa, Diana morre de um modo estranho, o que suscita alusões de Ahasverus à uma possível ação divina nesse episódio. A terceira parte corresponde ao extenso monólogo da personagem principal pouco antes de sua morte, em que ela chega à conclusão que o verdadeiro responsável pelo sofrimento dos homens é Deus.

Na estalagem, a primeira conversa tem Diana como principal interlocutora, as outras duas personagens quase não falam. Ela conta sobre sua vida com Tobias a quem atribui tudo o que ela é no momento e relata a história de uma jovem que vende seu corpo para conseguir o perdão de seus pecados ao chegar a Jerusalém. Essa moça, diz Diana, considera que vender seu corpo é um pecado justificável, uma vez que esse ato tem um objetivo mais elevado que é ir a Terra Santa conseguir o perdão e a purificação de sua alma: "Ese cuerpo que no significa nada... el cuerpo que no vale absolutamente nada...” (LAGERKVIST, 1963, p. 19). A idéia de pecado é relativizada: a prostituição, condenada veemente pelos textos bíblicos, é, na concepção da moça que tem como destino a Terra Santa, permitido se o objetivo for obter o perdão divino em uma terra considerada consagrada pela religião cristã. E a negação do corpo 
em favor do espírito, que vemos aqui, lembra em parte as previsões feitas por Deus a Jesus no Mar da Galiléia em O Evangelho Segundo Jesus Cristo, segundo o qual o homem, em vista da religião cristã, castigaria o próprio corpo, para fazer a vontade de Deus, a fim de obter a salvação: “A alma, meu filho, para salvar-se, precisa do sacrifício do corpo” (SARAMAGO, 2001, p. 389).

A segunda conversa é entre Ahasverus e Tobias. Esse conta o motivo que o fez desejar ir a Terra Santa. Segundo ele, durante a guerra, entrou em uma cidade totalmente deserta e encontrou uma mulher já morta. Ela se encontrava marcada por estigmas. O estado dela tocou-lhe de tal forma que se viu interessado em ir a Terra onde Jesus morreu por causa dessa mulher, pois ela levava no corpo as marcas do martírio do filho de Deus. Para Ahasverus, a mulher foi um ardil que "Ele” usou para manipular Tobias:

- No hay limites para el trabajo que se toma para si se trata de quien ha elegido.

- ¿Que ha elegido?

- Sí. Entonces no larga a presa. No la deja escapar jamás. Ya nunca le devulve la libertad... Pero bien se ve que yú no sabes que es eso de estar perseguido por Dios (LARGERKVIST, 1963, p. 54).

Ahasverus demonstra toda a sua insatisfação diante de Deus. Ele é o seu opressor, aquele que não permite que ele seja livre, nesse caso a liberdade almejada pela personagem é a morte, da qual ele foi privado por não ajudar Jesus. Para ele, a morte é a verdadeira terra santa, onde se pode encontrar realmente paz e repouso: "Y pensó para si mismo, sin dicirlo: ¡Qué felicidad la de poder morir! Ese es el país al que verdaderamente se debe aspirar. El país de la muerte, la tierra santa...” (LARGERKVIST, 1963, p. 98). Esse é o pensamento de Ahavereus a respeito da morte de Diana, a quem ele inveja por poder morrer, condição que lhe foi negada por uma maldição lançada por Cristo.

Na última parte da narrativa, Tobias embarca para Terra Santa e Ahasverus fica em terra pensando sobre a sua situação e sua relação com Deus. É nesse momento que ele percebe que Jesus, a quem ele odiou por muitos anos é apenas um desgraçado como todos os outros homens:

¡Él sacrifica los hombres! ¡Exige sacrificios constantemente, sacrificios humanos, crucificaciones! Así es, se quieres oírme. Yo lo sé, yo que arrastrado está maldición a través de las edades, que la he arrastrado como Tú has arrastrado tu cruz pero mucho más tiempo que Tú. La maldición que me señalaba como el enemigo de Dios, el negador, el blasfemador, el hombre sublevado contra Dios. Porque es Él quien me ha maldecido y no Tú. Lo sé, ahora por fin lo he comprendido. Tú no has hecho más que pronunciar las 
palabras que Él te inspiraba. Era Él quien poseía el poder y la venganza. ¿Qué poder tenías Tú? Tu no eras más que un pobre ser desamparado, sacrificado, abandonado. Ahora comprendo. Que Tú eras mi hermano. Que quien pronunció la maldición sobre mi cabeza era mi propio hermano, un desdichado. Él mismo un maldito (LARGERKVIST, 1963, p. 110-1).

Nesse monólogo, como podemos perceber, Ahasverus chega à conclusão de que Deus é o responsável pelo seu sofrimento e pelo de todos os homens. Jesus não fez mais que pronunciar as palavras que seu pai colocou em sua boca, sendo ele também um desgraçado, um amaldiçoado. Essa manipulação divina, que Ahaverus finalmente percebe nessa narrativa será marcante no romance de Saramago, onde em vários momentos Deus coloca as palavras na boca de Jesus, manipulando-o como bem entende como se Cristo fosse uma simples marionete. Ao chegar à conclusão de que Jesus é um desgraçado como ele, Ahasverus percebe que Deus é o responsável pelo homem estar afastado do divino e é nesse momento que consegue sua liberdade, podendo finalmente morrer em paz: "E inundado de esa luz terrestre que no tenía nada de extraordinario, abandonó este mundo” (LAGERKVIST, 1963, p. 117). 


\section{Judas Iscariotes: de um reles traidor a filho de Deus}

A tradição cristã relega a Judas o pior papel entre os discípulos: o de traidor de Cristo. Assim, a sua figura é relembrada negativamente todo sábado de aleluia, em que garotos fustigam um boneco representado figura daquele que cometeu o pior de todos pecados. Em $A$ Divina Comédia, de Dante, essa personagem é merecedora do maior castigo e sofre uma pena dobrada, merecendo ser mastigado eternamente pelo monstruoso Lúcifer no último círculo do Inferno $^{25}$. Nos evangelhos pouco sabemos de Judas além do fato de ele ter sido recrutado por Jesus como um dos doze apóstolos, de ter traído seu mestre por trinta moedas pratas e depois com remorsos se enforcado em uma figueira.

Nas releituras heterodoxas da história de Jesus, que estamos tratando aqui, há a clara tendência de recuperação dessa personagem que, em certos casos, recebe melhor consideração que o próprio Cristo. Em O código dos códigos, Frye comenta o modo como o Romantismo procurou tratar as personagens rejeitadas da Bíblia, de modo que figuras renegadas como “Caim, Ismael, Esaú, Saul, até o próprio Lúcifer são todos heróis românticos (FRYE, 2004, p. 219)”. Nesse contexto podemos inserir também a figura de Judas Iscariotes que será, de certa forma, redimido de seu erro nessas releituras.

Já em A vida de Jesus, Renan argumenta que as acusações feitas pela tradição contra ele têm alguma coisa de injustas, pois, embora não se possa negar que Judas contribuiu para a prisão de seu mestre, seu ato pode não ter tido toda a perversidade que se lhe atribui:

\footnotetext{
Um leve despeito bastava para fazer de um sectário um traidor. Mas se a insana cobiça de algumas moedas transtornou a cabeça do pobre Judas, não parece que perdesse completamente o sentimento moral, pois que, vendo as conseqüências de seu erro, arrependeu-se e, diz-se, suicidou-se (RENAN, 1926, p. 308).
}

Nessa perspectiva, a traição de Judas não passou de um momento de fraqueza do “traidor”, ou de algum desentendimento dele em relação ao seu mestre. Apesar disso, o autor ressalta que ele manteve um sentimento de moral ao suicidar-se e isso, de certa forma, deveria

\footnotetext{
${ }^{25}$ Pra o da frente, a mordida era ligeira pena, em confronto com a gadanhada que por vez lhe arrancava a pele inteira.

"Esse, que sofre aí pena dobrada, é Judas Iscariote”, disse o guia, “co’ as perna fora e a cabeça abocada. (ALIGHIERI, 2001, p. 227)
} 
absolvê-lo de parte de suas culpas. Obviamente que dizer isso resulta numa total discordância com o que foi disseminado durante séculos na cultura cristã.

Dentro dessa linha de pensamento, no poema “A Caridade e a Justiça”, encontrado em A Velhice do Padre Eterno, de Guerra Junqueiro, o tema da traição vem à tona. Judas após ter traído Jesus é visitado por um gigante chamado Remorso que o faz ver o grande mal, de ordem moral, que cometera ao trair seu mestre. Consciente de seu erro, o traidor decide se enforcar, mas no momento em que está para levar a cabo sua intenção a "voz celestial de Jesus moribundo" lhe concede o perdão, dizendo-lhe que seu ato não lhe causasse remorso, pois ele estava perdoado. Judas, porém, não aceita o perdão:

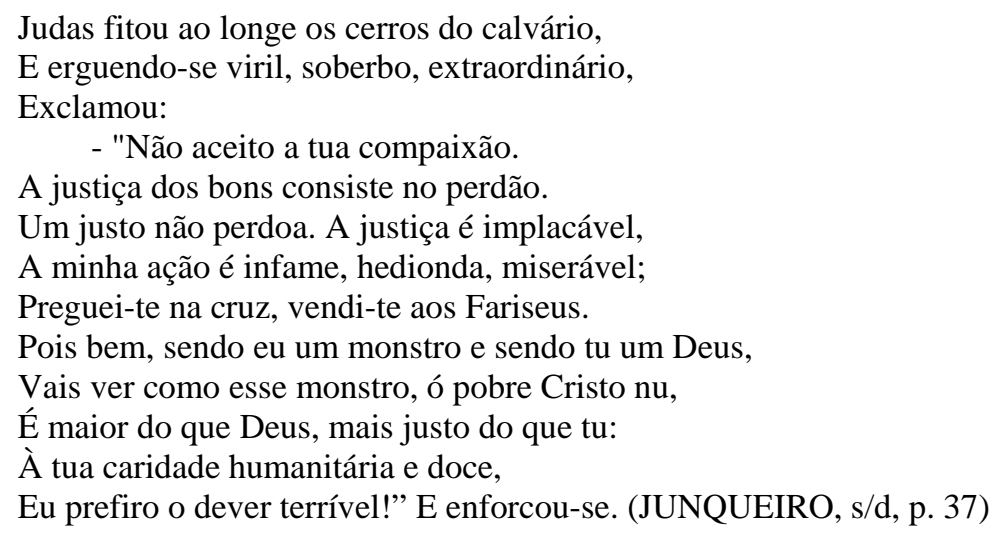

Os papéis entre Judas e Jesus são, de certa forma, invertidos. Cristo não é mais o justo na concepção do poeta: o seu perdão implica um não cumprimento da justiça. E nisso o traidor supera o seu mestre e mantém sua honra diante de um ser moribundo e insignificante. No momento em que Judas executa sua própria sentença pelo erro cometido ele se considera maior que Deus e mais justo que Jesus, que não tem ação nenhuma na execução dessa justiça: elas estão inertes, a justiça racionalizada dos homens supera a justiça divina. Aliás, como vimos acima, Renan atenua a culpa de Judas por esse ter se suicidado.

Em Memórias de Judas, a versão da traição é, segundo o próprio Judas Iscariotes, que é o narrador-personagem, fruto da antipatia que os outros discípulos tinham em relação a ele. O traidor dos evangelhos bíblicos é, nesse romance, não só o melhor amigo de Jesus, como o único entre os discípulos que não o abandonou na crucificação, como já vimos acima. De fato, podemos pensar que os traidores são todos os outros onze discípulos que o abandonaram.

O Judas de Nikos Kazantzakis não é apenas o melhor amigo de Jesus, é também seu braço direito e muitas vezes age como se fosse a própria consciência de Cristo. A traição 
nesse romance surge de um acordo entre as duas personagens. E o motivo de Jesus delegar a Judas o papel da traição é o de que este discípulo é mais forte do que os outros e até mesmo que o próprio Cristo:

- Será, sim, Judas, meu irmão. Deus lhe dará tanta força quanto você precisar, porque é necessário. É necessário que eu seja morto e que você me traia. Nós dois precisamos salvar o mundo. Ajude-me.

Judas abaixou a cabeça e perguntou após um instante:

- Se você tivesse de trair seu senhor, seria capaz de fazê-lo?

Jesus refletiu por muito tempo e afinal respondeu.

Não, receio que não seria capaz. Foi por isso que Deus teve pena de mim e me deu a tarefa mais fácil: a de ser crucificado (KAZANTZAKIS, 1988, p. 432).

A inversão dos papéis é patente nesse diálogo. A crucificação de Jesus não é tão difícil se comparada ao papel que Judas representa na história que é o de ser o traidor. Borges em “Três versiones de Judas” (1944) vai além disso. Nesse conto, o narrador afirma que todas as coisas que se atribuem a Judas Iscariotes são falsas. Tal afirmação atribuída a De Quincey, é um pressuposto apresentado para se questionar a versão tradicional sobre o fato de Judas haver traído seu mestre, e por si só já é uma subversão do relato canonizado. No entanto essa subversão não para por aqui. O narrador desse conto atribui a De Quincey a especulação de que Judas teria entregado Jesus não de uma forma casual, decorrente de um momento de fraqueza humana, em que ele teria ficado tentado em receber as famosas trinta moedas de prata: Judas entregou o Redentor porque desejava que ele demonstrasse seu caráter divino e guiasse uma rebelião contra os romanos.

A argumentação principal que vai à contramão da versão ortodoxa do episódio da traição é atribuída à outra personagem do conto, Nils Runeberg. Ironicamente, argumenta-se que

Suponer un error en la escritura es intolerable; no menos intolerable es admitir un hecho casual en el más precioso acontecimiento de la historia del mundo. Ergo, la traición de Judas no fue casual; fue un hecho prefijado que tiene su lugar misterioso en la economía de la redención (BORGES, 1956, pp. 160-1).

Como podemos ver, o trecho alude a suposta infalibilidade da razão divina. O plano da redenção não poderia estar sujeito a um caso meramente casual, pensar isso seria intolerável. Na verdade o Evangelho de Mateus condiciona o episódio da traição a uma profecia 
encontrada no livro do profeta Jeremias ${ }^{26}$. E é a partir dessa reflexão que Runeberg desenvolve sua teoria que é sobremaneira surpreendente: "Judas refleja de algún modo a Jesus” (BORGES, 1956, p. 161). Runeberg argumenta que se Jesus dispunha dos consideráveis recursos que a Onipotência pode oferecer, ele não necessitaria de um homem para ajudá-lo a redimir os outros. Ou seja, como filho de Deus ele não necessitaria de que alguém o traísse para cumprir o seu papel na economia da redenção. E conforme vai desenvolvendo sua argumentação Runeberg se aproxima da heresia suprema. Para ele, a afirmação de que "fue hombre y que fue incapaz de pecado encierra una contradición; los atributos de impeccabilitas y de humanitas no son compatibles” (BORGES, 1956, p. 164). Podemos notar aqui o questionamento da ambígua humanidade do filho de Deus apresentada nas escrituras sagradas. Mas essa nova versão de Judas apresenta uma grande profanação da figura do filho de Deus. Diante de tudo que argüiu, Runeberg conclui que(:) "Para salvarnos, pudo elegir cualquiera de los destinos que traman la perpleja red de la historia; pudo ser Alejandro o Pitágoras o Rurik o Jesus; eligió un ínfimo destino: fue Judas” (BORGES, 1956, pp. 164-5).

O Deus reencarnado aqui não é Jesus, mas Judas. O filho de Deus é o próprio traidor e seu lugar não é o céu, mas o inferno. A inversão dos papéis é brutal e justifica-se, segundo o autor, pelo fato de que o maior sacrifício não é morrer na cruz e posteriormente receber toda honra e glória, mas se expor à execração de ser o traidor, figura necessária na economia da redenção. Na versão de Borges é o Filho de Deus quem trai o homem e não o contrário, pois o papel mais difícil dessa história é a traição e teria que ser realizado pelo mais forte, que nesse caso é o filho de Deus.

\footnotetext{
${ }^{26}$ No evangelho Judas se arrepende do que fez e vai aos sacerdotes entregar as trinta moedas de prata que recebera como pagamento pela traição. Os sacerdotes pegaram de volta o dinheiro mais não quiseram colocar nos cofres do Templo, por ser um dinheiro de sangue e por isso compraram "o campo do Oleiro" para o sepultamento de estrangeiros, que ficou sendo chamado "Campo de Sangue", segundo o evangelista. Ao final do relato Mateus cita Jeremias: "Com isso se cumpriu o oráculo do profeta Jeremias: E tomaram as trinta moedas de prata, o preço do Precioso, daquele que os filhos de Israel avaliaram, e deram-nos pelo campo do Oleiro, conforme o Senhor me ordenara". (Mt 27: 9).
} 


\section{O JESUS DE SARAMAGO}

También se le ocurrió que los hombres, a lo largo del tiempo, han repetido siempre dos historias: la de un bajel perdido que busca por los mares mediterráneos una isla querida, y la de un dios que se hace crucificar en el Gólgota. (Jorge Luis Borges, "El Evangelio según Marcos”)

\section{A natividade}

Se considerarmos os evangelhos bíblicos como mitos da origem do cristianismo, é possível perceber a necessidade que eles têm de se relacionarem com o Antigo Testamento e, conseqüentemente, com a versão judaica da criação do mundo, a criação de Adão e Eva e de sua queda, que aparece como a principal causa da atual situação humana, como pode ser visto nos episódios encontrados nos primeiros capítulos do livro de Gênesis. Segundo Eliade:

\footnotetext{
Não basta reconhecer a "origem”, é preciso recuperar o momento em que tal ou tal coisa foi criada. Ora, isso se traduz num "voltar atrás" até a recuperação do Tempo original, forte, sagrado. E (...) a recuperação do Tempo primordial, indispensável para assegurar a recuperação total do Cosmo, da vida e da sociedade, é obtida sobretudo através da reatualização do “começo absoluto”, isto é, da Criação do Mundo (ELIADE, 2004, p. 38).
}

Pode ser por esse motivo que o Evangelho de João inicia recuperando o tempo mítico da criação do mundo como ponto de partida para sua narração da história de Jesus: "No princípio era o verbo e o verbo estava com Deus e o verbo era Deus” (Jo 1:1). Frye caracteriza a abertura do Evangelho de João como “o antítipo cristão do relato da criação no Livro do Gênesis” (FRYE, 2004, p. 245), ainda segundo ele, pode ser que houvesse uma intenção original de que o livro de João fosse o primeiro do cânone do Novo Testamento, o que acabou não acontecendo e ele se tornou o quarto evangelho, interrompendo o fluxo narrativo existente entre Lucas e Atos dos Apóstolos. Parece interessante refletirmos sobre o significado da expressão “ser”, presente na abertura do Evangelho de João, para o pensamento religioso. Segundo Cassirrer, essa expressão unifica todo o sentido da divindade: o "Eu sou” forma como Deus ordena que Moisés o apresente aos filhos de Israel, no Êxodo, não necessita de mais explicações, é absoluto, não há porque questionar, pois estamos diante do inefável, de algo que "só pode ser predicado por si mesmo" (CASSIRER, 1972, p. 93): “Eu sou aquele 
que é" e não se discute mais isso. Cassirer afirma que "por meio desta transformação da existência objetiva no ser pessoal, eleva-se verdadeiramente o divino à esfera do 'incondicionado', a um domínio que não pode ser designado por nenhuma analogia com nenhuma coisa ou nome de coisa” (CASSIRER, 1972, p. 94). Ora, quando nos deparamos com o romance do Saramago, ficamos diante de uma série de possíveis designações que poderiam ser atribuídas ao Deus saramaguiano, que está longe dessa esfera do divino, do mítico.

Ao retomarmos a relação dos evangelhos com o início mítico, devemos lembrar também que o homem que inicia a religião cristã é diretamente relacionado com o primeiro homem do mito genesíaco. Em sua primeira epístola aos Coríntios, Paulo caracteriza Jesus como o novo Adão ${ }^{27}$, o início de um novo estado de coisas que se distingue daquele instaurado pela transgressão do primeiro homem, resultante na queda e na expulsão adâmica do paraíso. Essa relação pode também ser atestada pela genealogia do Evangelho de Lucas, que vai desde Adão até Jesus Cristo. No evangelho de Saramago, em que acompanhamos a desmitificação de textos bíblicos, essa relação mítica não se realiza, pois não se faz alusão a uma ordem anterior nos termos dos evangelhos bíblicos e Jesus seria, não fosse a sua situação “infeliz” de filho de Deus da qual ele procura se desvencilhar sem sucesso, um homem como outro qualquer.

Nesse sentido, a narrativa da natividade é de suma importância para a história de Jesus, pois os evangelistas se esforçam em enfatizar a sua ligação com a tradição sagrada anterior. Nos evangelhos bíblicos, o nascimento do herói se caracteriza como um milagre, fruto da intervenção divina, tal como, segundo os evangelistas, foi predito pelos antigos profetas, de modo que Jesus foi concebido pelo Espírito Santo ${ }^{28}$. E José, orientado por um Anjo, assumiu a paternidade legal da criança. Nos evangelhos de Mateus e Lucas é destacada a origem nobre da personagem mediante uma genealogia que o coloca como descendente

\footnotetext{
${ }^{27}$ Segundo Frye, “a encarnação foi uma descida voluntária a um mundo inferior, repetindo a criação de Adão; daí que Paulo caracterize Jesus como segundo Adão”. Essa relação se encontra em I Cor 15:45: “Assim está escrito: o primeiro homem, Adão, foi feito alma vivente, o último Adão tornou-se espírito que dá a vida".

${ }^{28}$ Em Mateus 1, 18: "A origem de Jesus Cristo foi assim: Maria, sua mãe, comprometida em casamento com José, antes que coabitassem, achou-se grávida pelo Espírito Santo”.

Em Lucas 1, 31-35: “'Eis que conceberás no teu seio e darás à luz um filho, e tu o chamarás com o nome de Jesus. Ele será grande, será chamado Filho do Altíssimo, e o Senhor Deus dará o trono de Davi, seu pai; ele reinará na casa de Jacó para sempre, e o seu reinado não terá fim'. Maria, porém, disse ao Anjo: ‘Como é que vai ser isso, se eu não conheço homem algum?' O anjo lhe respondeu: 'O Espírito Santo virá sobre ti e o poder do
} 
direto do Rei Davi, a mais importante liderança do povo de Israel, segundo a história contada no Antigo Testamento. É evidente que nos textos bíblicos não se discuta a contradição do fato de que Jesus não poderia ser inserido em tal genealogia, uma vez que não descende de José, que é uma espécie de pai adotivo, mas diretamente do Espírito Santo, é óbvio que tal discussão não interessa aos textos bíblicos.

Nos evangelhos bíblicos, o percurso de Jesus é sempre um dado a priori. Para os evangelistas, o seu nascimento, assim como a sua morte, representa o cumprimento das sagradas escrituras judaicas que prevêem a vinda de um messias. Assim, logo de início nos deparamos com o paradoxo da concepção virginal de Cristo, que o evangelista Mateus atribuiu ao cumprimento da profecia de Isaías, que se refere ao nascimento de uma criança que surgiria como um sinal do cumprimento das palavras de Deus, que havia prometido defender o Reino de Judá de seus inimigos:

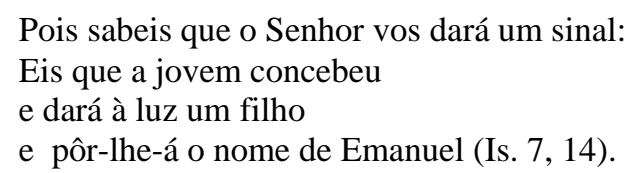

É a partir dessa profecia e da encontrada em Isaías 11, 1-9 que se estabelece o mito messiânico que é fundamental para a escrita da história de Jesus, uma vez que surge como força legitimadora dos relatos contidos nos evangelhos. Ao retomar a profecia, o evangelho de Mateus faz uma modificação notável em relação ao trecho citado acima, de modo que, em lugar da palavra “jovem” para designar a mãe da criança que deveria nascer, o evangelista utiliza a palavra "virgem”: "Eis que a virgem conceberá e dará a luz um filho e o chamarão com o nome Emanuel”.

No supracitado trecho do livro de Isaías, o termo "virgem” só aparece na versão grega $^{29}$, que é provavelmente de onde Mateus tirou a citação encontrada em seu evangelho. Mas no caso do texto em hebraico a palavra usada neste caso é ambígua e pode designar tanto uma mulher solteira, uma donzela, como uma mulher casada recentemente. No entanto, as versões do nascimento de Cristo encontrada nos evangelistas Mateus e Lucas enfatizam o caráter virginal da concepção. Kermode observa que as narrativas da Natividade apresentadas

\footnotetext{
Altíssimo vai te cobrir com a sua sombra; por isso o Santo que nascer será chamado Filho de Deus'”.

29 “A tradução grega traz "a virgem”, precisando assim o termo hebraico 'almah que designa quer a donzela, quer a jovem casada recentemente, sem explicitar mais” (Bíblia de Jerusalém, 2001, p. 1370, nota z).
} 
por estes evangelistas "são tentativas realmente independentes de estabelecer que o nascimento de Jesus foi de natureza apropriada a uma criança divina. Elas são mais bem pensadas como composições narrativas livres baseadas em dados selecionados do Antigo Testamento” (KERMODE, 1997, p. 425). É factível a intenção dos evangelistas de apresentar uma criança de natureza divina, de modo que o nascimento desta tem de ser um fato milagroso, que escape aos limites do meramente natural. De modo que Jesus jamais poderia ser filho biológico de José e nem a concepção poderia ocorrer do mesmo modo que se dá com os seres humanos, através da relação corporal entre um homem e uma mulher. Crossan acrescenta um outro fator que serve para valorizar o símbolo da virgindade no contexto em que os evangelhos se inserem. Segundo ele:

A virgindade é um símbolo vivo da beligerância fechado do grupo. É fácil entender a importância de Maria, uma mãe-virgem, nessas circunstâncias. Ela é exatamente aquilo que todos desejam, mas não podem conseguir: a maternidade sem a perda da virgindade; progenitura sem necessidade de sexo, e, portanto, disputa pelos recursos desejados sem que se precise colaborar para obter aquele que é mais importante (CROSSAN, 1994, p. 49).

No entanto, a virgindade de Maria apresentada pelos evangelhos de Mateus e Lucas parece ser contraditória, visto a tentativa destes mesmos evangelistas de relacionar Jesus a dinastia de Davi, uma vez que eles o fazem através de José que, como podemos perceber não tem nenhuma participação efetiva na concepção do menino Jesus:

Ambos, Mateus (1: 2-16) e Lucas (3: 23-38) fornecem uma árvore genealógica de Jesus, que reporta a Davi. Nessas duas genealogias José é o descendente do rei Davi, e não Maria. O fato mais extraordinário é que as genealogias de José são encontradas nos mesmos Evangelhos - Mateus e Lucas - que contam a história do nascimento virginal. Parece que os dois evangelistas não viam nenhum conflito entre Jesus descender de Davi através de José e sua concepção sem intervenção de um pai humano. Devemos ter em mente que ambas as genealogias concordam somente de Abraão até Davi. Os problemas internos de ambas as relações e suas diferenças consideráveis nos deixam a impressão de que foram construídas ad hoc, por assim dizer, com o intuito de provar a dinastia de Davi (FLUSSER, 2002, p. 8).

Relacionar Jesus à dinastia davídica é, como a idéia do nascimento virginal, uma tentativa de dizer que o herói destes evangelhos é o messias predito pelos antigos profetas ${ }^{30}$,

\footnotetext{
${ }^{30} \mathrm{O}$ trecho dos profetas que coloca o messias como descendente do rei Davi é o encontrado no livro de Isaías 11 , 1: “Um ramo saíra do tronco de Jessé, um rebento brotará de suas raízes”. Jessé era, no tempo do profeta Samuel, o pai de sete filhos, entre os quais, o mais novo, era Davi.
} 
segundo os quais o salvador do povo de Israel seria descendente do rei Davi, ou pelo menos é assim que os evangelistas interpretaram.

Por outro lado, nas releituras heterodoxas da história de Jesus, no momento em que se anuncia a morte de Deus, opera-se, inicialmente, uma total desmitificação da história bíblica. A intenção dos autores, principalmente no século XIX, parece ser a de apresentar uma versão de Cristo despido de sua divindade. Por conta disso, é impensável um nascimento que não corresponda aos padrões da natureza humana, de modo que a história de que Jesus foi concebido por uma virgem nem sequer é considerada por Renan, em A vida de Jesus, que, como já dissemos, tenta reconstituir historicamente o que poderia ter sido a vida de Cristo no mundo ao qual pertenceu. O fato, para o escritor francês, é que Jesus "nasceu em Nazaré, pequena cidade da Galiléia, desconhecida até então. Toda a sua vida foi designado pelo nome de 'Nazareno' e só por um esforço que não se compreende é que se poderia, segundo a lenda, dá-lo como nascido em Belém” (RENAN, 1926, pp 16-7).

Em Memórias de Judas, o nascimento de Jesus é colocado como um possível caso de adultério, uma vez que se desconfia que Jesus pode não ser mesmo filho de José. Mas nem por um momento se alude a possibilidade de uma concepção virginal, pois, como já vimos, a tendência desse romance é dessacralizar os milagres relatados nos evangelhos bíblicos. Assim, o nascimento da figura mais importante do cristianismo se resume a um fato apenas banal e corriqueiro, como se pode notar pelo comentário de Ida, irmã de Jesus no romance:

O nascimento de meu irmão mais velho, conhecido presentemente pelo nome de rabino da Galiléia ocasionou entre meu pai e minha mãe recriminações de ciúmes e suspeitas injuriosas; foi por causa disso que meus outros irmãos não estimaram nunca Jesus que entretanto amava mais pai do que minha mãe (GATTINA, 1946, p. 286).

Já no século XX, outro autor que se refere ao nascimento de Cristo é Kazantzakis, em A Última Tentação de Cristo. Mas diferente dos autores citados acima, ele não descarta a natureza miraculosa do episódio, mas dá-lhe feições distintas da que ocorre nos evangelhos, de modo semelhante a Saramago, como veremos mais adiante. No romance grego, o nascimento de Jesus é antecedido por uma série de fatos excepcionais:

Atropelavam-se em sua mente as recordações dos sinais e prodígios que cercavam esse rapaz desde seu nascimento, e na verdade desde muito antes. Como por exemplo, quando os pretendentes estavam reunidos, o cajado de José, dentre tantos outros, foi o único a florir. Por causa desse sinal o rabino concedeu-lhe a mão de Maria, a bela Maria, que foi consagrada a Deus. E depois um raio caiu paralisando o noivo no dia do casamento antes que tivesse a oportunidade de tocar a noiva. E mais tarde, como se disse que a noiva 
cheirou um lírio branco e concebeu um filho. E ainda como na noite de seu nascimento, Maria sonhou que os céus se abriam, os anjos desciam, alinhavam-se como pássaros no telhado humilde de sua casa, construíam seus ninhos e começavam a cantar; e como alguns protegeram a soleira da porta, outros entraram em seu quarto, acenderam um fogo e aqueceram a água para banhar o recém-nascido; e ainda outros prepararam uma sopa para a parturiente tomar... (KAZANTZAKIS, 1988, p. 27).

O relato da natividade mantém, até certo ponto, o caráter especial para o nascimento de uma criança divina, assim como nos evangelhos bíblicos. Porém, apresenta detalhes até mesmo cruéis no que diz respeito aos envolvidos. José, por exemplo, é atingido na cabeça por um raio no dia de seu casamento com Maria o que o impediu de tocá-la, o objetivo disso seria que ela se mantivesse virgem como prediz a tradição cristã. Mas, ao contrário dessa mesma tradição, é negada a José a condição de homem santo e justo, que, orientado por um Anjo, todo apoio a Virgem e assumiu a paternidade de Jesus. A história do nascimento, em Kazantzakis, é conhecida por todos os moradores do local, que parecem encará-la como algo natural, tal é a impressão que passa o modo como Judas considera a situação: um milagre. A intervenção divina, neste caso, é totalmente forçada, opressora, não há o menor consentimento das personagens envolvidas. O relato é marcado por uma ironia impensável ao tom solene dos evangelhos bíblicos, de modo que a concepção virginal tem espaço na narrativa de Kazantzakis, mas de um modo totalmente enviesado em relação ao que ocorre na tradição cristã ortodoxa. Assim, Maria, a bem-aventurada entre as mulheres, torna-se mais uma desgraçada:

Enviuvou-se antes de se casar; era mãe sem ter filhos; e agora estava ficando mais velha (os cabelos brancos multiplicavam-se a cada dia) sem, no entanto, jamais ter sabido o que significava ser jovem, sem jamais ter sentido o calor de um marido, o encanto e o orgulho de ser esposa e mãe (KAZANTZAKIS, 1988, p. 35).

A mulher conformada e bem-aventurada dos evangelhos por ter sido escolhida para ser a mãe do filho de Deus é substituída por uma mulher sofredora e desencantada com a vida. Ela é uma das primeiras vítimas do cristianismo, pois lhe foram negados todos os prazeres terrenos reservados a uma mulher na sua condição: não soube o que era ser jovem, não conheceu homem, é mãe sem ter filhos. Em certo sentido, a Maria, de O Evangelho Segundo Jesus Cristo, assemelha-se a essa personagem de Kazantzakis, pois se caracteriza como uma sofredora, a quem foi imposta uma tarefa que não lhe apetecia, a de ser a mãe de um homem destinado à morte. 
Na obra de Saramago, o nascimento de Jesus encontra um paralelo em Levantado do Chão. A narrativa do nascimento de Maria Adelaide é repleta de elementos caros à narrativa evangélica e que ecoarão mais tarde na elaboração de O Evangelho Segundo Jesus Cristo. João Mau-Tempo, António Mau-Tempo e Manuel Espada, avô, tio e pai da recém-nascida, são apresentados como os três reis magos que visitam o menino Jesus segundo o evangelho de Mateus. Mas ao contrário desses, os novos reis magos do romance não possuem nenhuma riqueza, apresentando apenas a pobreza que os caracterizam em sua vida de camponeses. Assim, Maria Adelaide pode ser equiparada a Cristo, numa clara inversão de valores relativos a uma sociedade patriarcal e machista. Seu nascimento:

permite evidentemente ao narrador recuperar o nascimento do Cristo. Nesse novo contexto há elementos novos e elementos que se repetem. Para inaugurar o novo será uma menina que nascerá, embora, já como modelo numa terra de pastores. (...) No centro do quadro, a menina está deitada sem a passividade do Menino-Deus. Porque é humana, chorou ao nascer; porque, como herança dos poderosos, só guardou os olhos azuis vindos de um distante século XV, haverá de gritar outras vezes como adverte o narrador, gritos de luta a ecoar no latifúndio. (CERDEIRA DA SILVA, 1989, p. 214).

O Cristo-Menina, que surge na citação acima, caracteriza-se como uma inversão patente da narrativa bíblica, pois é mulher e humana, sua relação com a história de Jesus é feita através de elementos inseridos na narrativa que remetem ao nascimento do messias, em que se destaca a "visita dos Reis Magos”, apresentada por Mateus ${ }^{31}$, que no caso do romance são o avô, João Mau-Tempo, o tio, Antônio Mau-Tempo, e o pai, Manuel Espada. Nos evangelhos, embora o nascimento de Jesus ocorra da forma mais humilde possível, numa manjedoura, os eventos que o cercam, tal como a anunciação dos anjos e a visita dos pastores, louvando-o como um ser de importância divina, dão um caráter singular e conveniente ao nascimento de um deus. O contexto em que nasce Maria Adelaide é outro, mas o modo como o narrador descreve o cenário guarda diversas semelhanças com a narrativa bíblica.

Sant'Anna, em sua tese de doutorado O Sagrado em Saramago, demonstra que os nascimentos de Maria Adelaide e Jesus apresentam características semelhantes, repetindo-se,

\footnotetext{
${ }^{31}$ Em Mateus 2, 1-2; 9-11: “Tendo Jesus nascido em Belém da Judéia, no tempo do rei Herodes, eis que vieram magos do Oriente a Jerusalém, perguntando: 'Onde está o rei dos judeus recém-nascido? Com efeito vimos a sua estrela no seu surgir e viemos homenageá-lo’. (...) E eis que a estrela que tinham visto no seu surgir ia à frente deles até que parou sobre o lugar onde se encontrava o menino. Eles revendo a estrela, alegraram-se imensamente. Ao entrar na casa, viram o menino com Maria, sua mãe, e, prostrando-se, o homenagearam. Em seguida, abriram seus cofres e ofereceram-lhes presentes: ouro, incenso e mirra”.

O Evangelista Lucas se refere à visita de pastores, em lugar dos magos, no capítulo 2.
} 
inclusive, “algumas expressões referentes ao parto” (SANT’ANNA, 2005, p. 79). Para Ferraz, a neta de João Mau-Tempo representa uma denúncia da misoginia cristã, cuja doutrina repousa em três figuras masculinas, de modo que, no caso de Levantado do Chão, “o narrador corrói o discurso bíblico que privilegia os homens em detrimento das mulheres, elegendo para Cristo uma menina: Maria Adelaide” (FERRAZ, 2003, p. 23).

Já em O Evangelho Segundo Jesus Cristo, a concepção de Jesus, mesmo conservando sua natureza divina, passa obrigatoriamente pelo ato sexual. Não parece que o romancista tenha a intenção de apresentar algo mais próximo da realidade, como faz Renan ou Gattina, mas de inverter ironicamente os motivos que regem os textos bíblicos, a narrativa puramente religiosa. Desse modo, Maria não é uma virgem quando engravida, pois o melhor que Deus pode fazer, para gerar o seu filho, é misturar seu esperma ao de José, no momento do ato sexual entre o "santo casal”, como Maria virá saber algum tempo depois no romance, por intermédio de um Anjo:

\begin{abstract}
Deves saber, ó Maria, que o Senhor pôs a sua semente de mistura com a semente de José na madrugada em que concebeste pela primeira vez, e que, por conseguinte e conseqüência, dela, da do Senhor, e não da do teu marido, ainda que legítimo, é que foi engendrado seu filho Jesus. (...) Então o Senhor não me escolheu, Qual o quê, o Senhor ia só a passar, quem estivesse a olhar Tê-lo-ia percebido pela cor do céu, mas reparou que tu e José eram gente robusta e saudável, e então, se ainda te lembras de como estas necessidades se manifestavam, apeteceu-lhe, o resultado foi, nove meses depois, Jesus, E há a certeza, o que se chame de certeza, de que tenha sido mesmo a semente do Senhor que engendrou o meu primeiro filho, Bom, a questão é melindrosa, o que tu estás a pretender de mim é, sem tirar nem pôr, uma investigação de paternidade, quando a verdade é que, nestes conúbios mistos, por muitas análises, por muitos testes, por muitas contagens de glóbulos que se façam nunca as podemos ter absolutas (SARAMAGO, 2001, p. 311-2).
\end{abstract}

O Anjo, embora afirme que Jesus é mesmo filho de Deus, não se arrisca a dar certeza sobre o fato, usando o argumento anacrônico de que para se ter certeza seria preciso "uma investigação de paternidade”, algo semelhante a um teste de DNA. A própria expressão “conúbios mistos” é carregada de ironia, uma vez que atesta a incapacidade divina de engendrar seu próprio filho sem a ajuda humana, sem contar o fato de que o próprio anjo não se atreve a afirmar a paternidade de Jesus, em outras palavras, ele parece duvidar da palavra de seu senhor, algo impensável nos textos bíblico. Só mais tarde na narrativa, Deus confirmará ser o pai de Jesus, argumentando, quando questionado da veracidade dessa afirmação, que sua certeza se dá pelo fato de ele ser o que é: 
Bem vês, eu tinha misturado a minha semente na semente de teu pai antes de seres concebido, era a maneira mais fácil, a que menos dava nas vistas, E estando as sementes misturadas como podes estar certo de que sou teu filho, É verdade que nestes assuntos, em geral, não é prudente mostrar certeza, ainda menos absoluta, mas eu tenho-a, de alguma coisa me serve ser Deus (SARAMAGO, 2001, p. 366).

A resposta final dada por Deus é categórica e não abre espaço a questionamentos, reproduzindo assim o discurso religioso que se apresenta como inquestionável, pois se trata de uma palavra sagrada. No entanto, o contraste dessa resposta com a consideração feita por Deus de que não é prudente ter certeza no caso, ainda mais uma certeza absoluta, gera uma ironia que marca a elaboração do romance. Nele, o discurso religioso aparece sempre relativizado e a "verdade absoluta” da religião se transforma em verdades. É evidente que nos textos bíblicos não há nenhuma necessidade de se explicar os atos de Deus, como ocorre no romance de Saramago, que inverte os valores mítico-religiosos dos evangelhos, o que resulta na desmitificação das personagens dessa história. A imitatio Dei, que segundo Eliade ${ }^{32}$, é um fator de suma importância para a religião, extingue-se em O Evangelho Segundo Jesus Cristo. Jesus não quer seguir ao Deus dos hebreus, mas confrontá-lo, impedir que ele chegue aos seus objetivos. Dentro de um contexto puramente religioso, em que a verdade divina é absoluta e indiscutível, o ato dessa personagem é completamente impensável. No entanto, a relativização dessa verdade religiosa cria um ambiente propício para desmitificação da história de Cristo, tal qual a operada no romance, pois a palavra de Deus já não é mais inabalável e seu “filho” não é mais seu seguidor fiel, completamente incapaz de recusar ser o cordeiro para o sacrifício. Em O Sagrado e o Profano, Eliade afirma que “o homem religioso experimenta a necessidade de existir sempre num mundo total e organizado, num Cosmos” (2001, p. 43). Para Cassirrer, uma pessoa sob o encanto da intuição mítico-religiosa é como se vivesse em um mundo fechado, pois o "respectivo conteúdo momentâneo, ao qual se atrela o interesse religioso, preenche completamente a consciência, de modo que nada mais subsiste fora dele” (1972, p. 52). Assim, parece-nos que o mito tem como função eliminar o caótico, a relativização das coisas, criando um mundo mais coeso, uma realidade absoluta. Em $O$ Evangelho Segundo Jesus Cristo talvez seja possível pensar que o processo de desmitificação da história de Jesus consiste exatamente nesse processo de relativização do texto sagrado, que diante de uma leitura heterodoxa tem seus princípios fragmentados, não se podendo auferir

\footnotetext{
32 “O homem [religioso] só se torna verdadeiro homem conformando-se ao ensinamento dos mitos, imitando os
} 
mais a sua totalidade, o seu caráter de verdade absoluta, acima de qualquer questionamento. E, nesse sentido, a humanização da personagem, no romance, pode ser caracterizada também como sua desmitificação: O Jesus de Saramago não é mais um deus no sentido que lhe dá o mito bíblico, ele já não paira acima dos anseios humanos, e nem mesmo surge com a missão de heróis civilizadores, mas, como um homem, ele quer defender a vida humana sem as regras impostas pela religião que Deus quer fundar como veremos mais adiante. Se há algo realmente sagrado para o Jesus saramaguiano, este sagrado é a vida humana. E uma vez que ele não se encontra acima dos demais homens, sua história não é mais um mistério a ser desvendado, e nem é mais cercada pela aura de uma “verdade” absoluta: a verdade mítica é relativizada, no romance e nada aconteceu realmente, como se quer no mito, pois se trata de uma versão entre várias outras ${ }^{33}$.

É possível perceber que a releitura dos evangelhos feita por Saramago não parece ter por objetivo mostrar um mundo mais racional, marcado, por exemplo, pela ausência de milagres, como é o caso de autores do século XIX, como Renan, Eça de Queiroz e Gattina. Para eles, como já vimos, Jesus é apenas um homem sem qualquer distinção de natureza divina e Deus é fruto da mente humana. A intenção que parece evidente é a de destacar as contradições inerentes aos textos bíblicos, utilizando-se principalmente do mecanismo da paródia e nesse sentido sua releitura da história de Cristo se assemelha à de A Última Tentação de Cristo, em que Jesus aparece como o messias, porém em um contexto que difere muito do dos evangelhos, onde podemos notar o modo irônico e sarcástico com que o autor grego relê diversos episódios bíblicos, como já vimos acima. Assim, em Saramago, a relação sexual entre José e Maria, inexistente na concepção virginal de Cristo apresentada pelos textos bíblicos, surge como um momento oportuno, uma escolha casual e proveitosa, “a

deuses” (ELIADE, 2001, p. 89).

${ }^{33}$ Em O Sagrado e o Profano, Eliade afirma que o "mito conta uma história sagrada, quer dizer, um acontecimento primordial que teve lugar no começo do Tempo, ab initio. Mas contar uma história sagrada equivale a revelar um mistério, pois as personagens do mito não são seres humanos: são deuses ou Heróis civilizadores. Por esta razão suas gesta constituem mistérios: o homem não poderia conhecê-los se não lhe fossem revelados. O mito é pois a história do que se passou in illo tempore, a narração daquilo que os deuses ou os Seres divinos fizeram no começo do Tempo. 'Dizer' um mito é proclamar o que se passou ab origine. Uma vez 'dito', quer dizer, revelado, o mito torna-se uma verdade apodítica: funda a verdade absoluta. 'É assim porque foi dito que é assim', declaram os esquimós nestsilik a fim de justificar a validade sagrada de sua história sagrada e suas tradições religiosas. O mito proclama a aparição de uma nova ‘situação' cósmica ou de um acontecimento primordial. Portanto, é sempre a narração de uma 'criação': conta-se como qualquer coisa foi efetuada, começou a ser. É por isso que o mito é solidário da ontologia: só fala das realidades, do que aconteceu realmente, do que se manifestou plenamente” (ELIADE, 2001, p. 84-5). 
maneira mais fácil, a que menos dava nas vistas”, para que Deus pudesse gerar o filho que desejava:

\begin{abstract}
Deus, que está em toda parte, estava ali, mas, sendo aquilo que é, um puro espírito, não podia ver como a pele de um tocava a pele do outro, como a carne dele penetrou a carne dela, criadas uma e outra para isso mesmo, e, provavelmente, já nem lá se encontraria quando a semente sagrada de José se derramou no sagrado interior de Maria, sagrados ambos por serem a fonte e a taça da vida, em verdade há coisas que o próprio Deus não entende, embora as tivesse criado. Tendo saído para o pátio, Deus não pode ouvir o som agónico, como um estertor, que saiu da boca do varão no instante da crise, e menos ainda o levíssimo gemido que a mulher não foi capaz de reprimir (SARAMAGO, 2001, p. 27).
\end{abstract}

Assim, ao conceber Jesus Maria já não é mais uma virgem, como nos evangelhos. A concepção desta criança se dá através de um ato carnal, do modo mais humano possível. Deus aparece como um mero espectador, sua ação se resume a misturar o esperma dele ao de José, e ocorre de forma bem sutil durante o processo. É possível notar que, ironicamente, nem o próprio Deus é capaz de sobrepor-se a certos eventos humanos, como esse a que nos referimos: Jesus é concebido naturalmente através da relação física entre um homem e uma mulher. É clara a ironia do narrador ao inverter os evangelhos bíblicos, onde acrescenta ainda que "em verdade há coisas que o próprio Deus não entende, embora as tivesse criado". Limita-se o caráter divino que rege a narrativa religiosa dos evangelhos, nas quais Deus é um ser onisciente, onipresente e onipotente. A força divina é limitada: Deus pode ter o seu filho, mas precisa da ajuda de um homem para isto, uma vez que ele é um “puro espírito”, o que o impede de fazer certas coisas como os homens que ele próprio criou.

Ao contrário do que afirma a tradição cristã, Jesus não será o único filho de Maria, mas apenas o mais velho, pois mais tarde terá irmãos e irmãs. Flusser aponta para este fato em seu livro Jesus:

Jesus tinha quatro irmãos e várias irmãs. A família de Nazaré incluía, por conseguinte, ao menos sete filhos. Se aceitarmos o nascimento virginal como histórico e também admitirmos que os irmãos de Jesus eram seus irmãos e irmãs verdadeiros, devemos concluir ser ele o primogênito de Maria. Mesmo os que consideram as narrativas de nascimento de Mateus e Lucas como não-históricas, devem admitir que Jesus pode muito bem ter sido o filho mais velho da família (FLUSSER, 2002, p. 11).

Como podemos perceber, a idéia de que Jesus tinha irmãos e irmãs é retomada em $O$ Evangelho Segundo Jesus Cristo, o que contraria a tradição cristã que afirma que os irmãos e irmãs citados nos Evangelhos Sinóticos são na verdade primos e primas de Jesus segundo uma possibilidade de tradução do hebraico e do aramaico, em que irmãos pode significar 
também parentes próximos. Não se admite, assim a idéia de que a virgindade de Maria tenha sido violada. A ironia do texto saramaguiano, porém, corrói tal possibilidade apresentada pela tradição cristã e não aceita que nem mesmo Jesus tenha nascido de uma mulher virgem, embora, sem muitas explicações, além das já comumente aceitas pela fé cristã, que não admite questionamentos, afirme que Jesus é realmente filho de Deus que, como vimos acima, utiliza-se de seu poder, para misturar seu esperma ao de José no momento em que este copulava com Maria, para assim gerar um filho que mais tarde lhe seria útil em seu propósito tirânico de expandir seus domínios a toda humanidade.

No romance, os valores religiosos do texto bíblico são invertidos. A palavra divina não é mais incontestável. A verdade absoluta da religião é relativizada. Nos dois primeiros capítulos do evangelho de Mateus, o evangelista relaciona os fatos narrados ao cumprimento de profecias por cinco vezes. Um dos episódios é o da matança dos inocentes por Herodes, que na tentativa de matar o menino Jesus, manda eliminar todas as crianças de Belém com a idade de até dois anos:

Então Herodes, percebendo que fora enganado pelos magos, ficou muito irritado e mandou matar, em Belém e em todo seu território, todos os meninos de dois anos para baixo, conforme o tempo de que havia se certificado com os magos. Então cumpriu-se o que fora dito pelo profeta Jeremias:

Ouviu-se uma voz em Ramá

choro e grande lamentação:

Raquel chora seus filhos

e não quer consolação,

porque eles já não existem. (Mt. 2, 16-18)

O mesmo episódio é retomado pelo romancista sob um outro ponto de vista caracterizadamente crítico e irônico. Para o evangelista, na citação acima, não parece importar muito o fato de terem sido assassinadas as crianças, mas sim o fato de que se cumpriu mais uma das antigas profecias, esta atribuída ao profeta Jeremias. Não é assim que ocorre no romance, cuja tendência é a desmitificação do texto bíblico. O referido episódio tem uma importância fundamental na história contada por Saramago. É por não ter se preocupado em avisar aos pais das outras crianças sobre as intenções de Herodes, preocupando-se apenas em salvar seu próprio filho, que José começou a ter os pesadelos que o acompanharam até a hora da morte, e que serão como uma herança para Jesus. Ao comentar o episódio, o narrador saramaguiano o faz com uma intensa ironia: 
Um anjo realmente merecedor desse nome até podia ter poupado o pobre José a estas agonias, bastava que aparecesse em sonho aos pais dos meninos de Belém, dizendo a cada um, Levanta-te, toma o menino e sua mãe, foge para o Egito e fica lá até que eu te avise, pois Herodes procurará o menino para o matar, e desta maneira salvam-se os meninos todos, Jesus escondido na cova com os seus paizinhos, e os outros a caminho do Egito, donde só regressariam quando o mesmo anjo, tornando a aparecer aos pais deles, dissesse, Levanta-te, toma o menino e sua mãe e vai para a terra de Israel, porque morreram os que atentavam contra a vida do menino.

Como sabemos, em Mateus, um anjo aparece a José e lhe avisa quais são as intenções de Herodes, possibilitando, assim, a fuga da "santa família” para o Egito. No romance, o mesmo não acontece, como já vimos, mas o narrador não deixa de fazer uma nova leitura do episódio encontrado no texto bíblico, a referência a ele é claríssima. Um anjo, diz o narrador, poderia ter aparecido aos pais das vítimas e dito a elas que fugissem para o Egito, de onde só retornariam quando esse mesmo anjo dissesse que o rei Herodes, que desejava a morte das crianças, já estava morto, tal como ocorre no Evangelho de Mateus, um anjo aparece a José e diz a ele que fuja para o Egito e só retorne quando for de lá chamado. A ironia do narrador é marcante, pois ele coloca o texto bíblico sob um novo viés, em que se pode dizer que a vida humana é colocada acima dos interesses divinos. E nesse sentido, não apenas o menino Jesus deveria ser salvo, como é dado a entender no texto bíblico, que condiciona o fato ao cumprimento de mais uma profecia: "Do Egito chamei meu filho" ${ }^{34}$. No romance de Saramago, o narrador questiona o porquê da não preocupação em salvar as outras crianças do destino trágico que tiveram: morrer, antes mesmo de ter experimentado a vida, como todos os outros homens. Afinal, diz ele ironicamente que um "anjo realmente merecedor desse nome”, um representante da vontade divina, deveria também se preocupar com a vida dos outros inocentes, pois dados os seus atributos de uma criatura benéfica, segundo o senso comum, esta seria nada mais, nada menos que a sua função.

No entanto, numa paródia do episódio da anunciação encontrado no evangelho de Lucas $^{35}$, é o próprio Lúcifer, um anjo caído que, disfarçado de mendigo ${ }^{36}$, diz a Maria que ela

\footnotetext{
${ }^{34}$ Em Mt. 2, 13-14: “eis que o Anjo do Senhor manifestou-se em sonho a José e lhe disse: 'Levanta-te, toma o menino e sua mãe e foge para o Egito. Fica lá até que eu te avise, porque Herodes vai procurar o menino para o matar'. Ele se levantou, tomou o menino e sua mãe, durante a noite, e partiu para o Egito. Ali ficou até a morte de Herodes, para que se cumprisse o que dissera o Senhor por meio do profeta:

'Do Egito chamei o meu filho'”.

${ }^{35}$ Em Lucas 1, 26-35; 38: "No sexto mês, o anjo Gabriel foi enviado por Deus a uma cidade da Galiléia, chamada Nazaré, a uma virgem desposada com um varão chamado José, da casa de Davi; e o nome da virgem era Maria. Entrando onde ela estava, disse-lhe: 'Alegra-te, cheia de graça, o Senhor está contigo!' Ela ficou intrigada com essa palavra e pôs-se a pensar qual seria o significado da saudação. O Anjo, porém, acrescentou:
} 
está grávida. E ele o faz destacando o fim destinado a todos os homens, nascer e morrer e assim continuamente:

Mulher, tens um filho na barriga, e esse é o único destino dos homens, começar e acabar, acabar e começar, Como soubeste que estou grávida, Ainda a barriga não cresceu e já os filhos brilham nos olhos das mães, Se assim é, deveria meu marido ter visto nos meus olhos o filho que em mim gerou, Acaso não olha ele para ti quando o olhas tu, E tu quem és, para não teres precisado de ouvi-lo da minha boca, Sou um anjo, mas não o digas a ninguém (SARAMAGO, 2001, p. 33).

O anjo, que mais tarde no romance saberemos ser o próprio Diabo, anuncia friamente a Maria que ela está grávida. Não há motivos para engrandecimentos, como ocorre no texto bíblico, pois o nascimento que está por vir será comum a todos os outros na história da humanidade. E, assim, destaca-se especialmente o caráter humano da personagem no momento de seu nascimento:

O filho de José e de Maria nasceu como todos os filhos dos homens, sujo do sangue da mãe, viscoso das suas mucosidades e sofrendo em silêncio. Chorou porque o fizeram chorar, e chorará por esse mesmo e único motivo. Envolto em panos, repousa na manjedoura, não longe do burro, porém não há perigo de ser mordido, que ao animal prenderam-no curto (SARAMAGO, 2001, p. 83).

O Evangelho Segundo Jesus Cristo, bem como outras obras a que nos referimos neste trabalho, retoma os evangelhos bíblicos de forma paródica. Isto se evidencia tanto no questionamento irônico dos pressupostos religiosos que marcam o texto bíblico, como pudemos perceber acima, como na própria estrutura do romance que pode ser caracterizado pelo contraste em relação aos evangelhos bíblicos, cuja história é por ele retomada. Assim, segundo Fokkema, o Jesus de Saramago se caracteriza como uma inversão do Jesus dos evangelhos e sua chave semiótica é "a reversal of godly rhetoric into human wisdom: this is

\footnotetext{
'Não temas, Maria! Encontraste graça junto de Deus. Eis que conceberás no teu seio e darás a luz um filho, e tu o chamarás com o nome de Jesus. Ele será grande, será chamado Filho do Altíssimo, e o Senhor lhe dará o trono de Davi, seu pai; ele reinará na casa de Jacó para sempre, e o seu reinado não terá fim.' Maria, porém disse ao Anjo: ‘Como é que vai ser isso, se eu não conheço homem algum?' O anjo lhe respondeu: 'O Espírito Santo virá sobre ti e o poder do Altíssimo vai te cobrir com a sua sombra; por isso o Santo que nascer será chamado Filho de Deus. (...) Disse, então, Maria: ‘Eu sou a serva do Senhor; faça-se em mim segundo a tua palavra!’ E o Anjo a deixou".

${ }^{36}$ É interessante notar que no episódio relativo ao nascimento de Maria, no romance de Kazantzakis, é Deus que aparece disfarçado de mendigo, conforme pensam os moradores da aldeia: "Os anjos entravam e saíam da sua pobre choupana, e uma noite os vizinhos viram o próprio Deus atravessar a soleira, disfarçado de mendigo. Sabiam que era Deus porque a casa imediatamente balançou como se sacudida por um terremoto, e nove meses depois sucedeu o milagre: Ana, mulher já de seus sessenta anos, deu à luz Maria” (KAZANTZAKIS, 1988, p. 47). É factível que durante esse romance Deus recebe várias vezes o atributo de Diabo como se ele fosse os dois
} 
not blunt reversal, but one that is based on irony, understatement and implication" (FOKKEMA, 1999, p. 397). Para Horácio Costa, o romance de José Saramago que pode ser lido como uma livre paráfrase do Novo Testamento, realiza alterações não ortodoxas na história contada pelos evangelhos. E nesse sentido, o "writer insists more in the humanity of the sacred family than its holiness" (COSTA, 1996, p. 194), e, assim, entre outras coisas, ele contradiz a virgindade de Maria, como vimos acima.

E esta humanização da personagem central de O Evangelho Segundo Jesus Cristo vai se evidenciando a cada página do romance. Como vimos acima, há uma preocupação dos evangelistas em enfatizar a natureza divina de Jesus, relacionando-o a figuras importantes do mito bíblico, através de recursos, como as genealogias encontradas em Mateus e Lucas, por exemplo, além da reiteração de que a história de que estão narrando é um cumprimento das profecias judaicas. Assim, o nascimento do Cristo bíblico em uma manjedoura pode ter como objetivo demonstrar sua grandeza, pois sendo uma divindade, rebaixa-se ao nível dos homens, com a intenção de restaurar a harmonia deste mundo. Para o Jesus de Saramago, nascer em uma manjedoura representa apenas a falta de condições para algo melhor, dada a extrema pobreza de seus pais:

Às tantas, o infante Jesus acordou, mas agora a valer, que antes mal abrira os olhos quando sua mãe o enfaixara para a viagem, e pediu alimento com a sua voz de choro, a única que ainda tem. Um dia, como qualquer de nós, outras vozes virá aprender, graças às quais saberá exprimir outras fomes e experimentar outras lágrimas (SARAMAGO, 2001, p. 96).

Assim, o menino Jesus se alinha no mesmo nível de outras personagens de Saramago, tal como os que encontramos em Levantado do Chão que, ora e outra, são comparados ao próprio Cristo pela vida sofrida a que estão submetidas no Latifúndio.

Em sua releitura dos evangelhos bíblicos, parece evidente que Saramago não pretende oferecer uma versão mais racional da história, em que Jesus apareça totalmente humanizado, tal como fazem autores como Eça de Queiroz e Gattina, nem escrever uma espécie de biografia do herói dos evangelhos, como faz Renan. O modo como Saramago relê os evangelhos está mais próximos daquilo que fazem autores do século XX, algo semelhante ao que ocorre, por exemplo, na peça de Raul Brandão e Teixeira de Pascoaes, Jesus Cristo em Lisboa, ou no romance de Kazantzakis. Em ambos os casos Jesus não aparece desdivinizado, 
ele mantém seu status de filho de Deus, no entanto é o modo como essa personagem é apresentada nessas obras que dá o tom heterodoxo dessas releituras. No caso da peça portuguesa Jesus aparece com todas as características que lhe são peculiares nos textos bíblicos: é o novo contexto em que ele é inserido que o diferencia do Cristo bíblico. Em $A$ Última Tentação de Cristo, Jesus é o filho de Deus que, ao contrário de seu homônimo dos evangelhos, não tem vontade de seguir o seu papel messiânico, o que faz forçado por seu pai celeste, algo que de certo modo também ocorre com o Cristo saramaguiano. Assim, para Leyla Perrone-Moisés, a razão que move Saramago "é a da ficção, e esta exige do leitor um outro tipo de fé, que não é menos misteriosa e apaixonada do que a religiosa” (PERRONEMOISÉS, 1999, p. 240). 


\title{
2. O menino Jesus
}

A história do menino Jesus é praticamente ignorada pelos escritores do cânone bíblico. Como já dissemos acima, Lucas é o único que se refere a um episódio isolado da história de Jesus e o motivo para isso talvez seja a tentativa de conformar a sua escritura a um topos biográfico grego, que requer que um homem prodigioso tenha também uma infância prodigiosa. Apenas os apócrifos, de forma anedótica, referem-se à infância de Cristo. As releituras dos evangelhos que apresentamos nesse trabalho também não dizem muita coisa. Saramago é certamente quem delineia melhor uma imagem do menino Jesus, caracterizandoo, em seu romance, como uma criança qualquer, pobre e camponesa, sem qualquer fato que indicasse sua divindade. Além dele, dentre os autores que citamos nesse trabalho, podemos citar Kazantzakis que se refere a um momento da infância de seu herói, procurando elucidar a paixão de Jesus por Maria Madalena, que remonta aos tempos de infância em uma pequena aldeia:

\begin{abstract}
Madalena saltou de súbito de dentro da multidão e pregou os olhos no filho de Maria, que ainda vinha subindo. Seu coração enchia-se de tristeza quando ela recordava os momentos em que, ainda pequenos, brincavam juntos: ele com três, ela com quatro anos. Que alegria profunda e inefável haviam experimentado então! Que doçura indescritível! Pela primeira vez, os dois haviam percebido o fato ao mesmo tempo nítido e obscuro de um ser homem e o outro, mulher. Dois corpos que pareciam outrora ter sido um, e que algum Deus cruel separara. Agora as partes encontravam-se novamente e procuravam juntar-se, reunir-se (KAZANTIZAKIS, 1988, p. 46).
\end{abstract}

A paixão de Jesus por Maria Madalena é um fato de extrema relevância na narrativa de Kazantzakis, uma vez que é talvez a principal fonte dos conflitos internos da personagem central do romance, que não tem vontade de cumprir o seu papel como o messias escolhido por Deus, mas deseja viver como um homem comum, casando-se com Maria Madalena. O narrador não fala mais sobre a infância de sua personagem, mas dá a perceber que ela foi como a de qualquer outra criança, fora os fatos miraculosos que marcaram o seu nascimento. É na sua adolescência, no momento de oficializar um compromisso com a moça com que desejava casar que as coisas desandam para Jesus:

Dois corpos que pareciam outrora ter sido um, e que algum Deus cruel separara. Agora as partes encontravam-se novamente e procuravam juntar-se, reunir-se. Quanto mais cresciam, mais claro percebiam o milagre de um ser homem e o outro, mulher. E olhavam-se com um pavor mútuo, como dois animais selvagens esperando que a fome aumentasse e que chegasse a hora em que fluiriam um para dentro do outro, unindo o que Deus separara. Foi 
então que, numa noite festiva em Caná, quando o amado lhe estendeu a mão para lhe dar a rosa e firmar o noivado, o Deus impiedoso descera sobre eles, separando-os mais uma vez. E desde então... (KAZANTZAKIS, 1988, p. 46).

O casamento com sua prima, Maria Madalena era um dos maiores desejos de Jesus no romance de Kazantzakis. No entanto, por meio da intervenção divina eles não se unem, numa inversão das palavras ditas no evangelho "o que Deus uniu, o homem não separe” (Mc 10, 9). No entanto, enquanto homem e mulher se preparam para seguir o caminho que thes seria natural, Deus trata de separá-los mediante seus próprios interesses.

Em Levantado do Chão, Saramago parece querer aproximar todas as crianças nascidas em meio à pobreza do latifúndio à história do menino Jesus, antecipando o Cristo-menino que criaria cuja história contaria anos mais tarde:

E um maltês meio tonto que no dia seguinte ali passou, garantiu, por alma da própria mãe ainda viva, que aqueles celestes sinais anunciavam que numa malhada em ruínas, a três léguas dali, tinha nascido, mas doutra mãe, e provavelmente não virgem, uma criança que só não seria Jesus Cristo se a não batizassem com esse nome (SARAMAGO, 2005, p. 81).

A partir disso é possível deduzir que na visão do romancista qualquer criança do campo poderia ser o menino Jesus, aproximados talvez pela precariedade de situação em que nasceram. Esse é provavelmente o caso de João Mau-Tempo que após a morte do pai, João Mau-Tempo é elevado à condição de "homem da casa”, expressão irônica no que diz respeito a essa personagem, que, no momento em questão, não passa de uma simples criança pouco nutrida, que mal tem força para o trabalho:

Agora João Mau-Tempo é o homem da casa, o mais velho. Morgado sem morgadio, dono de coisa nenhuma, pequena é a sombra que faz no chão. Arrasta os tamancos que sua mãe mandou fazer, mas os troços pesados caem-lhe dos pés, e ele inventa uns suspensores toscos que passando por baixo do rasto se vão prender a uns buracos na linha das calças. É uma figura grotesca, de enxadão às costas, maior do que ele...

O garoto Mau-Tempo é o mais velho entre seus irmãos e isso lhe traz o ônus de trabalhar para o seu sustento e o de seus irmãos, obrigação que ele mal consegue cumprir dada a sua fragilidade de criança pouco nutrida:

João Mau-Tempo não tem corpo para herói. É um pelém de dez anos retactos, um cavaco de gente que ainda olha as árvores mais como alpenduradas de ninhos do que como produtoras de cortiça, bolota ou azeitona (SARAMAGO, 2005a, p. 55). 
A referida inconsistência da personagem como herói da narrativa nos direciona para um tipo de figura que aparecerá em Levantado do Chão e será comum ao longo da produção romanesca de Saramago. Os principais protagonistas da ficção saramaguiana são representantes das classes populares, geralmente excluídas dos registros oficiais, que valorizam normalmente representantes de estratos economicamente mais ricos da sociedade. De forma que, assim como João Mau-Tempo, veremos, mais tarde, em O Evangelho Segundo Jesus Cristo (1991), um rapazito chamado Jesus, que compartilha de situação semelhante à personagem de Levantado do Chão: o menino Jesus de Saramago depende da compaixão alheia para não morrer de fome, quando, com apenas treze anos, após a morte de seu pai, sai de casa para conhecer seu passado. De modo que, quando meninos, essas duas personagens guardam alguma semelhança entre si: ambos são pobres e órfãos e levados pelas circunstâncias a agir como adultos sendo ainda crianças, pois ambos perdem a figura paterna, figura importante dentro da sociedade patriarcal em que estão inseridos.

Horácio Costa, em seu ensaio “A Construção da Personagem de Ficção em Saramago”, considera que “o clã dos trabalhadores rurais de Levantado do Chão é uma espécie de personagem coletiva” (COSTA, 1999, p. 215), de modo que, os Mau-Tempo se caracterizariam como uma arquipersonagem da obra posterior de Saramago. Assim, a saga dos Mau-Tempo começa com o relato da vida de Domingos Mau-Tempo que, segundo o ensaísta, é possivelmente a personagem mais complexa do romance, caracterizado como um

camponês-sapateiro levado ao suicídio pela circunstância dupla da condição social e de um temperamento lábil, e que o relato ressuscita sessenta anos depois para participar na caminhada final dos trabalhadores rumo a afirmação política como classe social definida, na época do 25 de Abril (COSTA, 1999, p. 214).

Domingos Mau-Tempo é sucedido por seu filho João, que segundo Teresa Cristina Cerdeira da Silva, “é a coluna-mestra de uma estrutura que começa a levantar-se e a adquirir contornos mais nítidos ao longo do romance cuja intriga ficcional está sustentada (...) por uma densa trama histórica” (CERDEIRA DA SILVA, 1989, p. 235). A João Mau-Tempo seguem seu filho, Antônio, e seu genro, Manuel Espada, todos envolvidos na luta diária dos camponeses alentejanos, seja pela sobrevivência, seja por almejar uma situação melhor do que a imposta pelas condições sociais do campo. 
De volta aos evangelhos, o único evangelista a falar algo a respeito da infância de Jesus resume em poucas palavras o que ela foi antes do episódio do Templo, em que o menino foi encontrado por seus pais entre os doutores a discutir trechos das escrituras sagradas:

Terminando de fazer tudo conforme a Lei do Senhor, voltaram à Galiléia, para Nazaré, sua cidade. E o menino crescia, tornando-se robusto, enchia-se de sabedoria; e a graça de Deus estava com ele (Lc 2, 39-40).

Como vemos, isso é tudo que os evangelhos bíblicos falam sobre a infância de Cristo. É possível imaginar que para os evangelistas não há interesse em mostrar como o herói se desenvolve, uma vez que para eles ele é um ser divino, cujo objetivo é um só: cumprir os desígnios divinos. Assim, a partir do trecho acima, ficamos sabendo que Jesus passou a sua infância em Nazaré, cidade onde viviam seus pais, e que cresceu em força e sabedoria com a graça de Deus. Além disso, só o supracitado episódio do Templo. O mesmo não ocorre no caso de Saramago que, antes de tudo, pretende humanizar sua personagem, daí uma hipótese possível da necessidade de referências maiores à infância da personagem.

Desse modo, o menino Jesus de Saramago não apresenta nada que o destaque dos outros. Pelo contrário, o narrador faz questão de nos alertar que ele não passa de uma criança comum, que como todas as outras tem que passar pelos estágios naturais de aprendizagem:

\begin{abstract}
Maria olha o seu primogênito, que por ali anda engatinhando como fazem todos os crios humanos na sua idade, olha-o e procura nele uma marca distintiva, um sinal, uma estrela na testa, um sexto dedo na mão, e não vê mais do que uma criança igual às outras, baba-se, suja-se e chora como elas, a única diferença é ser seu filho, os cabelos são pretos como os do pai e da mãe, as íris já vão perdendo aquele tom branquiço a que chamamos cor de leite não o sendo, tomam o seu próprio natural, o da herança genética directa, um castanho muito escuro que adquire aos poucos, à medida que se vai afastando da pupila, uma tonalidade como de sombra verde, se assim podemos definir uma qualidade cromática, porém estas características não são únicas, só têm verdadeira importância quando o filho é nosso ou, porque dela estamos tratando, de Maria (SARAMAGO, 2001, p. 127).
\end{abstract}

Parece evidente que a criança apresentada no evangelho de Saramago não revela nada de sobre-humano, em outras palavras, não há o que o diferencie de outras crianças fora o fato de ter uma mão específica: Maria. Mas até nisso ele se iguala a todas as outras crianças, pois como elas teve uma progenitora. Assim, o menino Jesus vai aos poucos assumindo características físicas que o assemelha a seus pais. E em consonância com esta caracterização humanizadora de Cristo, o narrador destaca o processo de aprendizagem, nos primeiros anos de vida do herói: 
Daqui por algumas semanas este menino fará suas primeiras tentativas para pôr-se de pé e caminhar, irá de mãos ao chão vezes sem conta e ficará a olhar em frente, a cabeça dificilmente levantada, enquanto ouve a voz da mãe que lhe diz, Vem cá, vem cá, meu menino, e não muito tempo depois sentirá a primeira necessidade de falar, quando alguns sons novos começarem a formar-se na sua garganta, e ao princípio não saberá que fazer com eles, confundi-los-á com os outros que já conhecia e vinha praticando, os do grito e os do choro, porém não tardará a perceber que deve articulá-los de um modo muito diferente, mais compenetrado, imitando e ajudando-se com os movimentos dos lábios do pai e da mãe, até que consiga pronunciar a primeira palavra, qual ela tenha sido não sabemos, talvez papa, talvez papá, talvez mamã (SARAMAGO, 2001, p. 127).

Ao enfatizar o processo de aprendizagem que caracteriza os primeiros contatos de uma criança com o mundo que o circunda, o narrador reforça a humanidade da personagem de seu romance e dá o tom da releitura que faz da história contada nos evangelhos: essa personagem é construída diante dos olhos do leitor e ao contrário do herói dos evangelhos não tem nada que possa defini-la de antemão, seu caráter é algo que vai se constituindo com o decorrer da narrativa. De modo que o herói do romance é tão ingênuo quanto qualquer outra criança em seus primeiros anos de vida:

o que sim sabemos é que a partir de agora nunca mais o menino Jesus terá de fazer aquele gesto indicador com a mão direita na palma da mão esquerda se a mãe e as vizinhas tornarem a perguntar-lhe, Onde é que a galinha põe o ovo, é uma indignidade a que se sujeita o ser humano, tratá-lo como um cãozito ensinado a reagir a um estímulo sonoro, voz , assobio ou estalo de chicote. Agora Jesus está capacitado para responder que a galinha pode ir pôr o ovo aonde quiser, desde que não faça na palma da sua mão (SARAMAGO, 2001, p. 127-8).

Desse modo, o Jesus de Saramago é uma criança que tem tudo a aprender. Em uma descrição longa e detalhada, o narrador do romance parece querer deixar bem claro as características da personagem que reforçam sua humanidade. Assim, ao mostrar o contato inicial do Jesus menino com o mundo e o processo de aprendizagem pelo qual ele passa em seu crescimento, o narrador evidencia que não há nada de excepcional em sua personagem, cujo fim é o mesmo de todos os homens: nascer, crescer e morrer. De modo que Jesus vai a escola para aprender o mesmo que todos os meninos judeus de sua época: a lei mosaica, pela qual em alguns anos terá o mesmo respeito que qualquer outro judeu:

Quando chegou aos cinco anos, o filho de José começou a ir à escola. Todas as manhãs, logo ao nascer do dia, a mãe levava-o ao encarregado da sinagoga, que, sendo os estudos de nível elementar, bastava para o efeito, e era ali, na própria sinagoga, feita sala de aula, que ele e os outros rapazinhos de Nazaré, até aos dez anos, realizavam a sentença do sábio, A criança deve criar-se na Tora como o boi se cria no curral. A lição acabava pela hora sexta, que era o nosso meio-dia de agora (...) Quando Jesus entrava em casa, o pai perguntava-lhe, 
Que foi que aprendeste hoje, e o menino, que tivera a sorte de nascer com uma excelente memória, repetia tintim por tintim, sem falhas, a lição do mestre, foram primeiro os nomes das letras do alfabeto, depois as palavras principais e, mais para diante, frases completas da Tora, passagens inteiras, que José acompanhava com movimento rítmicos da mão direita, ao mesmo tempo que acenava lentamente com a cabeça (SARAMAGO, 2001, p. 132-3).

Como vemos, Jesus inicia seus estudos em nível elementar, sendo educado como todos os outros meninos judeus com idade até aos dez anos. O objetivo, segundo o narrador, é realizar "a sentença do sábio": fazer com que todas crianças conheçam a Torá, e creiam nela piamente, porque é a única verdade que pode ser aceita. Sabemos isso pela comparação irônica que faz o narrador nessa passagem: “A criança deve criar-se na Tora como o boi se cria no curral”. Ora, sabemos que um boi no curral é condicionado a fazer apenas aquilo que querem que ele faça, sem questionamentos, e é assim que se deveriam criar as crianças judaicas, segundo o narrador da história que estamos analisando. Esse tipo de educação será no decorrer do romance criticado a partir das experiências da personagem que, ao perceber a contradição existente entre os ensinamentos que teve quando criança e a realidade a que está exposto, passará a questioná-los.

Neste ponto é interessante observar que Renan também se refere à infância de Jesus, procurando caracterizá-lo uma criança inserida na cultura judaica, sem contato com outras culturas, e, nesse sentido, ele teria tido um aprendizado um tanto provinciano, sem nada de universal, limitado a um local e uma época, tal como a que o narrador de $O$ Evangelho Segundo Jesus Cristo procura nos apresentar. Assim, para o escritor francês, Jesus nada “conheceu fora do judaísmo; seu espírito conheceu aquela ampla ingenuidade que sempre enfraquece uma instrução ampla e variada. Mesmo no seio do judaísmo, permaneceu estranho a muitos esforços paralelos aos seus” (RENAN, 1926, p. 28). 


\section{Jesus em busca de autoconhecimento}

Entre o episódio em que Jesus é encontrado entre os doutores do Templo e o início de sua carreira terrena nada é relatado sobre a personagem nos evangelhos bíblicos. Trata-se de um período obscuro que Saramago trata de preencher em sua releitura da história de Cristo. Renan também faz algumas alusões ao que Jesus pode ter sido e pode ter presenciado em sua juventude. Kazantzakis apresenta sua personagem como um jovem perturbado e doente, por se recusar a aceitar seu destino em detrimento de seus desejos íntimos. Saramago faz mais do que isso, ele preenche esse período obscuro da vida de Jesus com a história das peregrinações do herói em busca de autoconhecimento: ele quer, antes de tudo, saber quem ele é, quais as suas reais origens e qual o papel de sua existência. O filho de Maria tem perguntas e sai em busca de respostas e nisto se assemelha ao herói romanesco, cuja história, tal como foi definido por Lukács em sua Teoria do Romance, é “a história da alma que sai a campo para conhecer a si mesma, que busca aventuras para por elas ser provada e, pondo-se à prova, encontrar sua própria essência” (LUKÁCS, 2000, p. 91).

O tema da viagem como forma de autoconhecimento já esteve presente na obra de Saramago antes do romance que estamos analisando. Em A Jangada de Pedra (1986), a Península Ibérica não é a única a se deslocar. Também, nessa grande barca de pedra, cinco personagens, Joaquim Sassa, José Anaiço, Pedro Orce, Joana Carda e Maria Guavaira se vêem envolvidos em fatos insólitos que de alguma forma os relaciona com o desligamento dos países ibéricos do continente europeu. Por conta disso, eles se juntam em uma jornada, que a princípio visa buscar respostas para os acontecimentos, mas que continua sem um destino aparente, dado o caráter circular do ir e vir das personagens. Esse movimento é como o da vida "vê-se-lhe o princípio mas não se lhe conhece o fim" (SARAMAGO, 2001b, pp.223). Ao viajarem pela Península em busca do desconhecido, essas personagens anseiam, de certo modo, por dar um sentido para as suas vidas. Cada aventura representa uma experiência, que as modifica interiormente. As relações amorosas ${ }^{37}$ são um grande exemplo disso. É na

\footnotetext{
${ }^{37}$ Segundo Beatriz Berrini, nos romances de Saramago “o amor aparece como algo natural, tendo em si mesmo a sua justificação, sem necessidade de quaisquer sanções civis ou religiosas. Tal maneira de ver percorre toda a ficção de Saramago e, a cada romance, um homem e uma mulher, mais uma vez, se aproximam e se amam, chamem-se as mulheres Blimunda ou Lídia, Gracinda ou Maria Sara” (BERRINI, 1998, p. 90). Podemos pensar, então, na força poética que envolve a relação entre Jesus e Maria de Magdala. É semelhante a um ritual de passagem, em que Jesus transforma-se em um outro homem.
} 
relação com Maria Guaivara que Joaquim Sassa sabe pela primeira vez o que é amar: “o meu problema é que não sei de quem gostar e como se faz para continuar a gostar” (SARAMAGO, 2001b, p. 151). As cinco personagens de A Jangada de Pedra se delineiam perante nossos olhos a partir do momento em que saem em busca de respostas para os acontecimentos singulares que ocorrem em suas vidas e que, de alguma forma, cria laços entre cada uma delas, unindo-as em um mesmo destino, que é comum ao dos outros homens, pois a caminhada que elas empreendem "rumo ao conhecimento transforma-se no caminho a ser empreendido por todo ser humano” (LOPONDO, 1998, p.72). De certo modo, a viagem que as personagens de A Jangada de Pedra empreendem, assemelha-se a viagem de Jesus em busca do autoconhecimento.

São fatos insólitos que surgem com o desligar da Península Ibérica do resto da Europa que motiva as personagens de A Jangada de Pedra a iniciarem sua caminhada. Não menos insólitos são os pesadelos herdados por Jesus de seu pai, que surgem como uma espécie de castigo por um erro que ele não cometeu, e que o motivam a sair de casa e se tornar um andarilho. Para Lukács, o processo pelo qual foi concebida a forma interna do romance "é a peregrinação do indivíduo problemático rumo a si mesmo, o caminho desde o opaco cativeiro na realidade simplesmente existente, em si heterogênea e vazia de sentido para o indivíduo, rumo ao claro autoconhecimento" (LUKÁCS, 2000, p. 82). Parece-nos que é isto o que ocorre com a personagem central de O Evangelho Segundo Jesus Cristo, que procura um sentido para a sua vida e este é o que motiva a aventurar-se em lugares para ele desconhecidos até então. O resultado de sua busca não é algo previsível, mas que vai se desdobrando aos nossos olhos. É importante lembrar que na história original, contada pelos evangelhos bíblicos, nada disso é necessário para o desenvolvimento da personagem, cujos caracteres são de antemão dados a conhecer ao leitor, afinal Jesus é o filho de Deus e sua existência tem um único fim: fazer com que a vontade divina, que é manifestada através das antigas profecias judaicas, seja cumprida até os últimos detalhes. Não é o que ocorre no romance. Por outro lado, o Jesus de Saramago é um indivíduo que se forma no decorrer da narrativa em conseqüência das experiências que vai acumulando em sua aventura, que é a vida. E, deste modo, à medida que prossegue a sua busca por autoconhecimento, o herói da narrativa se depara com fatos e questionamentos das pessoas a sua volta que põem em xeque a educação religiosa e moral que 
recebeu em sua infância, passa aos poucos a questionar tais preceitos e se dar conta das contradições existentes em suas crenças.

Ao considerarmos outras releituras heterodoxas que vimos acima, podemos perceber, por exemplo, que o que ocorre com o Jesus saramaguiano é diferente daquilo que se dá com o herói da narrativa de Kazantzakis. Esse ao mesmo tempo em que não deseja seguir o seu destino, martiriza-se por julgar ser sua obrigação cumprir o seu papel como messias divino e esse é o seu drama. Parece evidente que nos dois romances o ideal de um Deus benigno e misericordioso do cristianismo entra em choque com a realidade em que se inserem os heróis, tanto o de Kazantzakis como o de Saramago, o que provoca em ambos os casos uma intensa ironia. O que diferencia essas duas releituras da história de Jesus é o modo como se caracteriza a personagem central em uma e outra narrativa. No caso de Kazantzakis, Jesus esboça uma reação ao destino que lhe é imposto, mas não segue adiante e acaba se conformando as exigências divinas. O Jesus saramaguiano, por outro lado, luta até o último momento por sua liberdade e questiona os motivos divinos quanto mais toma consciência deles. Ele se quer como um homem e toma partido da humanidade e o único modo de salvá-la não é morrendo na cruz como o filho de Deus, como no final das contas faz a personagem do romancista grego, mas tentando evitar que isto ocorra.

Evidentemente, há uma diferença ainda maior entre o Jesus de Saramago e os escritores do século XIX a que nos referimos no presente trabalho. Tanto para Eça de Queiroz, como para Gattina, seguindo na linha de Renan, a figura de Jesus é destituída de toda a sua divindade. Ele pode ser no máximo uma pessoa de destaque, como é caracterizado pelo escritor francês que o coloca ao lado de outras pessoas, consideradas por ele como grandes figuras históricas, como Çakya-Muni, Platão, S. Paulo, S. Francisco de Assis, Santo Agostinho. No caso dos outros dois autores Cristo é ironizado e até mesmo ridicularizado. E, nesse sentido, é do Jesus pessoano que a personagem de Saramago mais se aproxima. Eduardo Lourenço, ao considerar a Literatura Portuguesa, afirma que o menino Jesus de Caeiro-Pessoa "põe termo a um longo processo de desdivinização de Cristo e redivinização num sentido novo (religiosidade nova) de Jesus, oposto desde Antero (via Renan) ao Deus bíblico” (1986, p. 117). E como podemos perceber no poema VIII de “O guardador de rebanhos”, o menino Jesus é desdivinizado no sentido em que ele representa a negação da tradição cristã, ele abandona os céus e passa a viver numa aldeia, como um menino, 
valorizando assim a vida humana. E é nessa valorização do que é humano que reside a redivinização de Jesus, “a criança tão humana que é divina”. De certo modo, a personagem de O Evangelho Segundo Jesus Cristo passa por um processo semelhante. Em seu processo de aprendizagem, resultante de suas experiências de vida, o Jesus saramaguiano passa a negar sua natureza divina, dado o fato de que ele é o filho de Deus, e passa a valorizar a vida humana, que é, no romance, o que pode haver de mais sagrado. A relação sexual entre Jesus e Maria de Magdala, em que nos deteremos mais adiante, é, por exemplo, narrado como um evento sagrado, ao passo que o encontro de Jesus com Deus é permeado de sarcasmo e ironia por parte do narrador. Há de fato uma inversão de valores tanto no poema de Caieiro-Pessoa como no romance de Saramago: o humano se sobrepõe aos elementos divinos da cultura judaico-cristã e a vida humana é sacralizada dentro desse novo contexto literário.

Nesse percurso de dessacralização da figura de Jesus e sua ressacralização em outros termos, a busca de autoconhecimento que a personagem central do romance empreenderá é de extrema relevância na narrativa, pois e nesse período que ele será questionado sobre os dogmas de sua religião e instado a valorizar a vida, seja ela qual for. Assim, ironicamente, o narrador de O Evangelho Segundo Jesus Cristo, que antecipa os quatro anos que Jesus passará ao lado de Pastor, afirma que esse período é pouco importante para as intenções divinas:

\footnotetext{
Daqui a quatro anos Jesus encontrará Deus. Ao fazer esta inesperada revelação, quiçá prematura à luz das regras do bem narrar antes mencionadas, o que se pretende é tão-só bem dispor o leitor deste evangelho a deixar-se entreter com alguns vulgares episódios da vida pastoril, embora estes, adianta-se desde já para que tenha desculpa quem for tentado passar à frente, nada de substancioso venham trazer ao principal da matéria (SARAMAGO, 2001, p. 228).
}

O encontro com Deus é antecipado na seqüência dos fatos, como se fosse o mais importante. Ao período de quatro anos que Jesus passa ao lado de Pastor é conferida pouca importância por parte do narrador, que sugere ao leitor que pule estas páginas "que nada de substancioso venham trazer ao principal da matéria”. No entanto, podemos perceber que não é bem isso o que ocorre, pois é nesse período que a personalidade da personagem começa a se modificar, que suas conviç̧ões morais e religiosas começam a ruir diante dos questionamentos que seu novo mestre lhe faz. Assim, a relação com o divino passa para um segundo plano, torna-se factível o fato de que o mais importante para a personagem é o que resulta de uma experiência de vida, tal como a que ela terá ao lado de Pastor nesses “vulgares 
episódios da vida pastoril” ou em sua relação amorosa com Maria de Magdala como veremos mais adiante. Nessa narrativa saramaguiana, o mais importante é a travessia e não o seu fim:

O que interessa no ESJC não é o seu fim, mas sim sua travessia, já que o narrador principia o discurso in ultima res, colocando o leitor $a b$ initio, face a face com o encerramento da diegese/trama, a crucificação de Cristo, mediante uma prolepse já nas primeiras páginas do livro. O leitor fica sabendo o final da trama no início do romance, não há suspense, mas mesmo assim ele faz o percurso da leitura até o fim. É a travessia do ESJC que interessa bem como a face de Deus ali revelada, e não o seu final (FERRAZ, 2003, p. 156).

Assim, com a morte de seu pai terreno, Jesus sai de casa em busca de conhecer o lugar onde nasceu e descobrir mais sobre si mesmo. Esta necessidade de autoconhecimento surge diante das dúvidas que o assolam depois da morte de José. Como sabemos Jesus herda os pesadelos do pai, que são resultantes do episódio do massacre dos inocentes, em que José, podendo fazer algo, não o faz, preocupando-se apenas com o próprio filho. Assim, com as sandálias do pai e os pesadelos como herança, o filho de Maria passa quatro anos ao lado de Pastor (Diabo, algo de que a personagem ainda não tem consciência). E como um viajante o herói de O Evangelho Segundo Jesus Cristo começa a sua aventura pela vida, experimentando o seu primeiro sentimento de abandono:

Jesus, de joelhos, gritou, e todo o seu corpo ardia como se estivesse a suar sangue, Pai, meu pai, por que me abandonaste, que isto era o que o próprio rapaz sentia, abandono, desespero, a solidão infinda de um outro deserto, nem pai, nem mãe, nem irmãos, um caminho de mortos principiado (SARAMAGO, 2001, p. 189).

No início de sua viagem, Jesus, um garoto com apenas treze anos, sente-se abandonado. "Pai, meu pai, por que me abandonaste”, lembra o clamor do Cristo bíblico na cruz pouco antes de morrer. O abandono do herói dos evangelhos, porém, é algo calculado, apenas simbólico, pois esse herói tem que passar por tal sofrimento para que possa cumprir o seu destino de remir os pecados da humanidade, em outras palavras, ele já sabe o que vem a seguir, sua vitória é certa. O Jesus de Saramago, por outro lado, encontra-se de fato abandonado, com a morte de seu pai tudo que lhe resta é trilhar por um caminho desconhecido, condenado a sofrer com os pesadelos que herdou do pai até o último momento de sua vida. Na concepção do romance a vida é valorizada, a idéia do sacrifício humano é colocada como um absurdo. O herói saramaguiano paga pelo pecado do pai, assim como os homens foram condenados, segundo o texto bíblico, a pagar pela transgressão de Adão e Eva, que resultou na expulsão dos ancestrais míticos da humanidade do paraíso ou como os 
israelitas foram condenados a vagar quarenta anos no deserto pelos erros de seus pais: "Iahweh é lento para a cólera e cheio de amor, tolera a falta e transgressão, mas não deixa ninguém impune, ele castiga a falta dos pais nos filhos até à terceira e quarta geração” (Núm. 14,18).

Assim, no romance de Saramago, como já vimos, a palavra divina vai aos poucos sendo questionada. E Deus, apresentado pelos textos do Antigo Testamento bíblico como um pai severo que castiga seus filhos, passa a ser visto com outros olhos, que já não aceitam tão simplesmente seguir a vontade divina. Assim, o Todo-poderoso pode ser caracterizado como inimigo da humanidade, ou como uma entidade preocupada em realizar seus próprios interesses sem levar em conta as conseqüências disto para humanidade. Assim, a asserção bíblica de que os pais devem pagar pelos pecados dos filhos é posta em questionamento no texto saramaguiano, não há mais a aceitação pura e simples dos fatos: "Sobre a cabeça dos filhos há-de sempre cair a culpa dos pais, a sombra da culpa de José já escurece a fronte de teu filho. Disse Maria, Infelizes de nós. Disse o anjo, Assim é, e não tereis remédio” (SARAMAGO, 2001, p. 116).

Maria não se conforma com a vontade divina que diz que os filhos devem pagar pela culpa dos pais e lamenta os pesadelos do filho. O “Infelizes de nós” já aparece em obras anteriores a de Saramago. Em A Última Tentação de Cristo, Maria Madalena também se revolta contra a vontade divina, considerando Deus como o "inimigo", palavra geralmente utilizada na Bíblia para se referir ao Diabo: "Deus é o grande inimigo, pensava, sim, Deus. Ele nunca deixa de se intrometer. É perverso, ciumento. Não quer que ninguém seja feliz...” (KAZANTZAKIS, 1988, p.99). Em Muerte de Ahaverus, de Pär Lagerkvist, a personagem principal se convence ao final da narrativa que o grande culpado dos sofrimentos da humanidade é Deus, que não cansa de exigir o sacrifício dos homens, e nesse sentido Cristo não passa de um desgraçado como todos os outros homens. No final das contas Deus é quem afasta o homem do divino: “Dios es lo que nos separa de lo divino. Lo que nos impide beber en la fuente misma” (LAGERKVIST, 1963, p. 117).

De modo que, para o romance saramaguiano, que se insere neste rol de releituras heterodoxas do mito cristão, não faz sentido que alguém seja responsabilizado pelo erro de outrem. No caso do massacre das crianças de Belém o erro maior pode ser atribuído ao próprio Deus que não fez nada para impedir que a tragédia ocorresse, mesmo tendo poder 
para isso. Assim a imagem de Deus como a de um pai rigoroso, que ama seus filhos é desconstruída. Ele se torna no mínimo um ser cruel de quem a humanidade não tem como escapar. De forma que podemos inferir juntamente com Dowe Fokkema que o texto de $O$ Evangelho Segundo Jesus Cristo pode ser lido como um texto em que o julgamento individual prevalece sobre a aceitação não crítica da "verdade revelada” da religião cristã.

Como já foi dito, Jesus sai de casa em busca de respostas. E em certo momento da história, o narrador tece uma série de comentários a respeito da coragem do jovem filho de Maria, mostrando com certa dose de ironia, suas características humanas:

Este rapaz que vai a caminho de Jerusalém, quando a maioria dos da sua idade não arriscam um pé fora da porta, talvez não seja exatamente uma águia de perspicácia, um portento de inteligência, mas é merecedor do nosso respeito, tem, como ele próprio declarou, uma ferida na alma, e, não lhe consentindo a sua natureza esperar que lha sarasse o simples hábito de viver com ela, até chegar a fechá-la essa cicatriz benévola que é não pensar, foi à procura do mundo, quem sabe se para multiplicar as feridas e fazer, com todas elas juntas, uma única e definitória dor (SARAMAGO, 2001, p. 200).

Como podemos perceber, o Jesus de Saramago é apresentado como um simples rapaz, muito diferente sábio garoto de doze anos apresentado pelo evangelista Lucas: "talvez não seja exatamente uma águia de perspicácia, um portento de inteligência”, mas que merece respeito pela coragem sair para enfrentar o desconhecido. É interessante lembrar que Renan caracteriza Jesus como um jovem judeu que tem acesso ao mesmo aprendizado que os outros garotos de sua época, e que se destaca apenas por seu modo peculiar de perceber a realidade. ${ }^{38} \mathrm{O}$ modo como o filho de Maria é apresentado em A Ùltima Tentação de Cristo, sempre em dúvida sobre que caminho deve trilhar, vai bem de encontro ao comentário irônico do narrador de O Evangelho Segundo Jesus Cristo sobre sua personagem, pois a personagem de Kazantzakis não esbanja inteligência, mas pelo contrário precisa do apoio quase irrestrito de uma figura execrada pela tradição cristã, Judas Iscariotes, para seguir seu caminho rumo ao calvário, ela é, tal como o Jesus de Saramago, alguém que vive mergulhado em dúvidas e que é dominado pelo medo que seu destino lhe impõe. Como sabemos, a personagem de Kazantzakis se debate entre o que ele julga ser seu dever, que é cumprir o seu papel nos planos de Deus, e seu desejo de constituir uma família ao lado de Maria de Magdala, ao fim

\footnotetext{
38 “Jesus cursou pouco as escolas mais ilustres dos escribas ou soferim (talvez não as houvesse em Nazaré), e não alcançou nenhum dos títulos que dão aos olhos do vulgo os direitos de saber. Todavia, seria gravíssimo erro imaginar que Jesus foi o que chamamos um ignorante” (RENAN, 1926, p. 26).
} 
da narrativa ele acaba se entregando para o sacrifício, o que não irá ocorrer com o Jesus saramaguiano, o que pode ser apontado como uma diferença marcante entre essas duas personagens. O herói do romance português não se acomoda as circunstâncias e por isso dá início a sua caminhada para procurar as respostas que sua alma tanto almeja. Sabemos que na versão original apresentada pelos evangelhos bíblicos, Jesus não almeja nada disso, seu papel na existência já está determinado e sua vitória vem da própria perspectiva de que deverá sofrer pela humanidade, morrer crucificado e ressuscitar ao terceiro dia:

Quando estavam para subir para Jerusalém, ele tomou os Doze a sós e lhes disse, enquanto caminhavam: "Eis que estamos subindo para Jerusalém e o Filho do homem será entregue aos chefes dos sacerdotes e escribas. Eles o condenarão à morte e o entregarão aos gentios para ser escarnecido, açoitado e crucificado. Mas no terceiro dia ressuscitará” (Mt. 20, 1719)

A inversão paródica realizada tanto pelo romance de Saramago como pelo romance de Kazantzakis em relação ao texto bíblico provocam o rebaixamento da personagem Jesus e enfatizam a sua humanidade, uma vez que ela, no primeiro caso, está à busca de respostas e, no segundo, procurando um modo de escapar de seu destino, ao qual teme ${ }^{39}$.

Parece importante lembrar que há um evidente rebaixamento do herói saramaguiano em relação ao se homônimo dos evangelhos. Em Anatomia da Crítica, Frye considera que há uma tendência de rebaixamento do tom assumido pelos gêneros literários no decorrer da história. Assim enquanto no gênero épico, pertencente à Antiguidade, o tom é elevado, no romance, o tom é baixo. Deste modo, na epopéia, o herói é um ser superior aos demais homens tanto em condição como em relação ao meio, pois “o herói é um ser divino, e a estória sobre ele será um mito” (1973, p. 39). No caso do romance do romance do Saramago, bem como de outras obras que vimos na primeira parte desse trabalho como, por exemplo, $A$ Relíquia, de Eça de Queiroz, Memórias de Judas, de Gattina, ou A Última Tentação de Cristo, de Kazantzakis, o modelo adotado para construção do herói é o próprio homem e o seu modo

\footnotetext{
39 “Não quero me calar! - prosseguiu o rapaz com os nervos em frangalhos. - Agora que já comecei, é tarde demais. Não vou calar a boca. Sou mentiroso, hipócrita. Tenho medo da minha própria sombra. Nunca digo a verdade, não tenho coragem. Quando vejo uma mulher passar, enrubesço e abaixo a cabeça, mas meus olhos enchem-se de desejo. Nunca ergui minha mão para roubar, açoitar ou matar. Não por não ter vontade, mas por ter medo. Quero me rebelar contra a minha mãe, contra o centurião, contra Deus, mas tenho medo. Medo! Se você olhar dentro de mim verá o Medo, um coelhinho trêmulo, alojado em minhas entranhas. Só o medo, e nada mais. Ele é meu pai, minha mãe e meu Deus” (KAZANTZAKIS, 1988, p. 151). O Jesus de Kazantzakis está longe de ser a figura segura que é apresentada pelos evangelhos bíblicos. Ele é sempre inseguro e tem sempre dúvidas sobre o que fazer ou como agir em várias situações, e acaba sendo movido pelo medo. Assim, ele não
} 
de imitação é o imitativo baixo: "Não sendo superior aos outros homens e seu meio, o herói é um de nós: reagimos a um senso de sua humanidade comum, e pedimos ao poeta os mesmos cânones de probabilidade que notamos em nossa experiência comum” (FRYE, idem, p. 40). Assim, a distância que o herói assume em relação ao homem na epopéia é praticamente nula no romance: Jesus abandona o caráter divino dos evangelhos bíblicos e toma uma forma bem mais humana.

Depois de muitas peripécias, tais como dormir ao relento e ter subtraído o pouco dinheiro que carregava consigo por assaltantes com que teve a pouca sorte de encontrar em seu caminho, o Jesus de Saramago chega a Jerusalém. Sua primeira preocupação é ir ao Templo em busca de respostas sobre a culpa que herdou de seu pai. Ele quer saber o que seria a culpa e porque os filhos a herdam dos pais, assim como todos os homens pagam pela desobediência de Adão e Eva, que lhes custou a expulsão do Paraíso. Parece-nos que a idéia de "pecado original” originado a partir do texto bíblico e apregoado pela tradição cristã é colocado em questão e, ironicamente, ficamos sabendo que "o homem é livre para ser castigado", de modo que, aquilo que tradição cristã chama de "livre arbítrio" se transforma em uma espécie de pretexto para seu castigo, pois ele está condenado à eterna culpa imposta pelo discurso religioso. Assim, em O Evangelho Segundo Jesus Cristo "todas as personagens (...) são culpadas ou assim se sentem” (PERRONE-MOISÉS, 1999, p. 241). E o questionamento que se faz do pecado original, dogma da religião cristã, parece ser também um dos exemplos da desmitificação do texto sagrado. Segundo Eliade, para "o homus religiosus, o essencial precede a existência” (2004, p. 85), de modo que, o "é como é hoje porque uma série de eventos teve lugar ab origine” (Idem, p. 86). O “essencial”, no caso da cultura judaico-cristã, é o drama do Paraíso, em que nossos ancestrais míticos desrespeitam o desejo divino e comem da árvore da ciência do bem e do mal, localizada no centro do Jardim do Éden. Tal ação representa o pecado original que culmina com a expulsão do homem do paraíso. E é por conta disso que Cristo vem ao Mundo, para que através de seu sacrifício, o homem seja redimido da mancha do pecado original. Tanto a história do Gênesis que objetiva contar o que instituiu a condição humana e a história da redenção da humanidade contada nos evangelhos são mitos que, segundo Eliade, contam os eventos que resultaram na atual condição do homem religioso:

mantém relações como Maria Madalena, por exemplo, pois tem medo de que o castigo divino caia sobre ele. 
e ao fazê-lo, explicam-lhe, como e porque ele foi constituído dessa maneira. Para o homos religiosus, a existência real, autêntica, começa no momento em que ele recebe a comunicação dessa história primordial e aceita suas conseqüências. É sempre uma história divina, pois as personagens são Entes Sobrenaturais e os Ancestrais míticos. Um exemplo: o homem é mortal porque um Ancestral mítico perdeu, estupidamente, a imortalidade, ou porque um Ente Sobrenatural decidiu privá-lo da imortalidade ${ }^{40}$ ou porque, após um determinado evento mítico, ele se encontrou dotado simultaneamente de sexualidade e mortalidade etc (ELIADE, idem, p. 85-6).

Ao ironizar a idéia da culpa que o homem carrega desde os erros de seus pais, o narrador de O Evangelho Segundo Jesus Cristo opera a desmitificação da história bíblica, pois questiona a própria essência do mito cristão, a validade do pecado original: não faz sentido que o homem pague por um erro que não cometeu, pelo que possa ter ocorrido no drama inicial da humanidade, o pai de todos os pecados. Ora, a idéia de pecado gera a culpa e é a partir dela que Deus, no romance, pretende que Jesus convença o homem a aderir à nova religião.

É movido pela culpa que José vai buscar seu vizinho Ananias entre os feridos em Séforis e se depara com a morte. E é essa mesma culpa de José, manifestada a Jesus através de pesadelos, que faz com que ele saia de casa e procure respostas, pois ficamos sabendo por intermédio do escriba do Templo que

A culpa é um lobo que come o filho depois de ter devorado o pai, esse lobo de que falas já comeu o meu pai, Então só falta que te devore a ti, E tu, na tua vida, foste comido ou devorado, Não apenas comido e devorado, mas vomitado (SARAMAGO, 2001, p. 213).

É a culpa que impulsiona os passos de Jesus, o fato de ter sido o motivo, ainda que involuntário, da morte dos inocentes. Assim, ele sai do Templo refletindo sobre as respostas que recebeu do escriba e vai a procura de respostas para fatos que marcam a sua vida:

Jesus desce em direção a Belém, poderia agora reflectir nas respostas dadas pelo escriba, não apenas à sua pergunta, às outras antes da sua também, mas o que o perturba é a embaraçosa impressão de que todas as perguntas eram afinal uma só, e que a resposta dada a cada uma a todas servia, principalmente a última, que resumia tudo, a fome eterna do lobo da culpa, que eternamente come, devora e vomita (SARAMAGO, 2001, p. 214).

Jesus vai a Belém para conhecer o lugar onde nascera e ao chegar lá ouve a história da morte das crianças contada por uma das moradoras do local, história que já ouvira da boca de sua mãe. Encontra também Zelomi, a escrava que fora sua parteira, e ela lhe mostra a cova 
onde ele nasceu e conta-lhe alguns detalhes dos episódios funestos que ocorreram após seu nascimento. Por conta disso, Jesus conclui que o homem não passa de um joguete nas mãos de Deus:

\begin{abstract}
Jesus calou-se. Mal tinha ouvido as palavras de Zelomi porque o pensamento, como uma súbita fresta, abriu-se para a ofuscante evidência de ser o homem um simples joguete nas mãos de Deus, eternamente sujeito a só fazer o que a Deus aprouver, quer quando julga obedecer-lhe em tudo, quer quando em tudo supõe contrariá-lo (SARAMAGO, 2001, p. 219-20).
\end{abstract}

Se os evangelhos bíblicos procuram apresentar Deus como um espectador entristecido das más ações humanas, e justificar suas ações como a de um pai que procura corrigir os erros do filho, o romance, por outro lado, apresenta-nos uma deidade que se diverte promovendo a desgraça humana, um ser egoísta e mesquinho, cuja única preocupação é consigo mesmo, um Deus que vem direto do “céu sulfúrico” de Guerra Junqueiro para o romance de Saramago. Diante disso, o Jesus saramaguiano se dá conta de sua insignificância diante do poder daquele que tudo pode e, embora ainda tenha nesse momento uma formação profundamente religiosa, típica da sociedade da qual faz parte, ele começa a criticar aquele que antes respeitava. Os traços irônicos da narrativa se fazem evidente pela voz do narrador: "abriu-se para a ofuscante evidência de ser o homem um simples joguete nas mãos de Deus”. Deste modo, ao contrário do Jesus bíblico que está sempre de acordo com o que vem de Deus. A personagem saramaguiana começa a se posicionar do lado contrário: Um ser tão benigno não poderia ter permitido a morte de crianças inocentes e nem o sofrimento de seu povo. Estabelece-se, dessa forma, um conflito entre o Homem e Deus e o Jesus do romance começa a tomar seu lugar ao lado dos homens. Assim, as crenças do herói saramaguiano vão sendo postas em xeque, criando um conflito entre a educação religiosa que recebeu dos seus pais e o modo como ele passa a encarar o mundo.

\footnotetext{
${ }^{40}$ Os itálicos são meus, esse parece ser, a meu ver, o caso do drama do pecado original da cultura judaico-cristã.
} 


\section{Jesus e Pastor (Diabo)}

O tempo que Jesus passa ao lado de Pastor é sem dúvida fundamental para a formação da individualidade do herói. Várias de suas convicções morais e religiosas do filho de Maria são questionadas pelo seu novo companheiro, que na verdade é próprio Diabo. No romance, o anjo caído não é mais o tentador, como é apresentado nos textos bíblicos, mas pode ser caracterizado como uma espécie de mestre para o jovem Jesus.

Como vimos até aqui, a personagem central de O Evangelho Segundo Jesus Cristo recebeu uma educação religiosa tradicional, como a que receberam seus pais, baseada nos escritos judaicos que correspondem ao Antigo Testamento da Bíblia cristã. Ao lado do Pastor, toda essa formação moral e religiosa de Jesus passa a ser questionada, desde a fé irrestrita em Deus, que não permite questionamentos, até questões sexuais, que se caracterizam como um tabu para o filho de Maria, e que o seu novo companheiro coloca como uma necessidade intrínseca do ser humano:

Escolhe uma ovelha, disse, Quê, perguntou Jesus desnorteado, Digo-te que escolhas uma ovelha, a não ser que prefiras uma cabra, Para quê, Vais precisar dela, se realmente não és um eunuco. A compreensão atingiu o rapaz com a força de um murro. Porém, pior que tudo foi a vertigem de uma horrível voluptuosidade que do afogamento da vergonha e da repugnância num rápido instante emergiu e prevaleceu. Tapou a cara com as mãos e disse em voz rouca, Esta é a palavra do Senhor Se um homem se ajuntar com um animal, será punido com a morte, e matareis o animal, e também disse Maldito o que peca com um animal qualquer (SARAMAGO, 2001, p. 237).

Acima, Pastor oferece a Jesus uma ovelha para que ele saciasse os seus desejos sexuais. O garoto responde, utilizando-se de textos bíblicos ${ }^{41}$, que a proposta do companheiro era impensável, um desrespeito às Leis mosaicas. Mas, apesar de toda essa capacidade que a personagem tem em citar as escrituras, ficamos sabendo pelo narrador que instinto humano dela aflora e por um momento prevalece sobre a ideologia religiosa que impregna sua mente. E isto nos é passado com certa dose de ironia, "pior que tudo foi a vertigem de uma horrível voluptuosidade”. O caráter humano da personagem toma conta da cena, contrastando com a sua sabedoria religiosa, que seria própria do Cristo bíblico, como podemos observar, por exemplo, no modo como ele responde as tentações do Diabo no deserto ${ }^{42}$, citando, com

\footnotetext{
${ }^{41}$ Em Ex. 22,18: “Quem tiver coito com um animal será morto” e Dt. 27,21: "Maldito seja aquele que se deita com um animal”.

${ }^{42}$ Em Mt. 4, 1-11 e Lc. 4, 1-13.
} 
autoridade, trechos das escrituras. E a semelhança aqui com o herói de A Última Tentação de Cristo é marcante, pois essa outra versão de Cristo também é sempre atormentada por seu instinto humano ao qual resiste ao lembrar das conseqüências que lhe adviriam pelo desrespeito às leis divinas.

Assim como o Cristo bíblico, no episódio da Tentação no deserto, o Jesus saramaguiano, também se ancora em trechos do Pentateuco, porém, como podemos perceber, ele o faz sem muita convicção, pois está realmente tentado a seguir a orientação de seu novo mestre: há em seu íntimo um claro conflito entre o respeito às Leis mosaicas e a realização de seus desejos. À reação de Jesus, Pastor responde com ironia:

Ouvide, ouvide, ovelhas que aí estais, ouvide o que nos vem ensinar este sábio rapaz, que não é lícito fornicar-vos, Deus não o permite, podeis estar tranqüilas, mas tosquiar-vos, sim, maltratar-vos, sim, matar-vos, sim, e comer-vos, pois para isso vos criou a sua lei e vos mantém a sua providência (SARAMAGO, 2001, p. 238).

Como podemos observar, Pastor, neste momento da narrativa, vai apontando as contradições presentes na educação religiosa que Jesus recebeu em sua infância. Em sua fala, citada acima, ele enfatiza a proibição imposta pela religião em relação ao sexo e contrasta com o derramamento de sangue feito muitas vezes para agradar a Deus. Parece-nos que há aqui uma clara referência aos sacrifícios impostos pela religião à humanidade e que serão questionados por Jesus mais adiante na narrativa, quando esse encontrar com seu pai divino, no mar da Galiléia. É interessante notar, também, que o menino Jesus é aqui apresentado como um adolescente de educação judaica, que procura seguir os preceitos de sua religião, o que faz com que ele reproduza trechos da Lei mosaica, fato semelhante à observação que Flusser faz a respeito do Jesus apresentado pelos Evangelhos Sinóticos:

Jesus aproveitou a oportunidade para elucidar um ponto importante. Suas respostas, aqui e acolá, não eram tão revolucionárias como alguém inexperiente poderia imaginar. Seu discurso acerca da pureza e da impureza é quase uma peça de sabedoria moral popular e as palavras de Jesus, na discussão sobre as espigas no Schabat, harmonizam-se plenamente com as concepções dos escribas moderados (FLUSSER, 2002, p. 40).

Flusser, em seu livro Jesus, defende a tese de que o filho de Maria era um autêntico judeu e como tal respeitava a Lei como qualquer um de seus conterrâneos. No romance de Saramago, como podemos ver, o adolescente Jesus também se esmera em repetir os preceitos de sua religião contra as palavras de Pastor, para ele agressivas, pois divergem daquilo que aprendeu em sua infância. 
São vários os diálogos deste tipo entre Jesus e seu mestre, em que se põem em questão várias das conviç̧ões religiosas do filho de Maria. Pastor chega até mesmo a questionar a existência de Deus, afirmando que seria melhor que ele fosse mais que um, pois "assim haveria um deus para o lobo e um deus para ovelha, um deus para o que morre e um deus para o que mata, um deus para o condenado e um deus para o carrasco (SARAMAGO, 2001, p. 233)”. A resposta de Jesus é baseada naquilo que ele aprendeu, e o narrador, ironicamente, acrescenta que o garoto “quase chorava de piedosa indignação”. Como podemos perceber, o status de "verdade absoluta” atribuído pela religião aos textos bíblicos é, aos poucos desconstruído ao passar pelo crivo irônico da narrativa saramaguiana. Cerdeira da Silva, ao comentar a paródia em Memorial do Convento, procura mostrar como se dá o processo de readequação do texto bíblico e das convicções religiosas neste romance de Saramago, observações que, parece-nos, também se aplica à narrativa de O Evangelho Segundo Jesus Cristo:

poderíamos chamá-lo de heresia literária, uma vez que o texto primeiro passa por uma desconstrução que o leva primeiro a uma completa transfiguração no novo contexto. Não se trata de paráfrase, de reduplicação, mas de uma filtragem irônica que dilui o tom sempre nobre e laudatório do texto de origem, para reinscrevê-lo de forma inopinada no novo espaço narrativo. Ora esta é a fórmula que se utiliza também com o texto bíblico e as convicções religiosas. A ironia é cáustica e vai por em questão as respostas seguras e as certezas inabaláveis da ideologia (CERDEIRA DA SILVA, 1989, 88).

Como vemos, é esta filtragem irônica que rebaixa o tom elevado do texto bíblico, de modo que as convicções religiosas da personagem fundamentadas pelas escrituras sagradas começam são abaladas. Conseqüentemente, as estruturas de uma fé aparentemente inabalável começam a ruir e o herói da narrativa começa a duvidar de coisas que antes dava como certas e, dessa forma, passa por um processo de transformação que o diferenciará de seu homônimo bíblico, uma vez que mais tarde se oporá à vontade de Deus.

No decorrer da narrativa, deparamo-nos com um episódio em que Jesus sacrifica uma ovelha, atendendo a vontade de Deus. O filho de Maria ganhou o animal na primeira vez que foi a Jerusalém para oferecê-lo como sacrifício pascal, como ordena a Lei de Moisés. No entanto, tomado por um sentimento humano, sentiu dó do animal e poupou-o do sacrifício, cometendo, assim, seu primeiro delito contra os preceitos da religião de seus pais. Feito isto, tomou o animal para si e colocou-o junto com as ovelhas de que tomava conta em companhia de Pastor. Mais tarde, a ovelha desaparece, e Jesus sai a sua procura e ao encontrá-la, Deus 
lhe aparece e exige que ele lhe sacrifique a ovelha, como forma de firmarem uma aliança, ao que o filho de Maria obedeceu:

\begin{abstract}
Vá, despacha-te, tenho mais que fazer, disse Deus, não posso ficar aqui eternamente. Jesus empunhou o cutelo, avançou para a ovelha que levantava a cabeça, hesitante em reconhecêlo (...) Estás a chorar, perguntou Deus, Tenho os olhos sempre assim, disse Jesus. O cutelo subiu, tomou o ângulo do golpe, e caiu velozmente como o machado das execuções ou a guilhotina que ainda falta inventar. A ovelha não soltou um som, apenas se ouviu, Aaaah, era Deus suspirando de satisfação (SARAMAGO, 2001, p. 264).
\end{abstract}

Jesus, mesmo contrariado como se pode perceber, cumpre o desejo divino. E é com sarcasmo que o narrador faz menção do prazer que Deus tem ao ver a morte da ovelha. Segundo Ferraz, a "face de Deus, por meio da forte antipatia do narrador, vai-se revelando aos poucos: misógino, despótico e sarcástico” (FERRAZ, 2003, p. 165), e diante dessa figura “sádica” Cristo não encontra saída. Assim, enquanto nos evangelhos bíblicos, Cristo é tentado pelo Diabo no deserto, no romance é o próprio Deus quem o tenta e, mais do que isso, o $\operatorname{derrota}^{43}$, convencendo-o a tirar uma vida que ele tanto defendeu. Ironicamente, o Tentador nos Evangelhos Sinóticos, a quem a tradição cristã atribui a responsabilidade pelos males da humanidade, é quem se preocupa com a manutenção da vida. O sacrifício da ovelha é, segundo Ferraz, “é uma prolepse do sacrifício da espécie humana inteira e do próprio sacrifício de Cristo, representando, alegoricamente, todos os cristãos” (FERRAZ, 2003, p. 166).

Ao saber o que Jesus havia sacrificado o pobre animal, Pastor o expulsa de junto dele, alegando que o filho de Maria não aprendera nada e, de certa forma, encerrando uma fase na vida da personagem:

Quando Jesus chegou ao campo, Pastor olhou-o fixamente e perguntou, A ovelha, e ele respondeu, Encontrei Deus, Não te perguntei se encontraste Deus, perguntei-te se achaste a ovelha, Sacrifiquei-a, Porquê, Deus estava lá, teve de ser. Com a ponta do cajado, Pastor fez um risco no chão, fundo como rego de arado, intransponível como uma vala de fogo, depois disse, Não aprendeste nada, vai (SARAMAGO, 2001, p. 264-5).

É possível perceber que o que Jesus não aprendeu é o respeito pela vida, seja ela qual for, assunto em que Pastor tocou várias vezes em suas conversas com o garoto. A ironia disso é mordaz e descontrói e inverte valores importantes do texto bíblico, que apregoa a adoração e

\footnotetext{
${ }^{43}$ Ainda segundo Ferraz, na "narração do sacrifício da ovelha, a carnavalização do personagem Deus é clara; é ele quem tenta Cristo no deserto e o derrota. De todos os personagens com os quais o narrador não simpatiza,
} 
o temor a Deus sem abrir espaço para questionamento, mesmo que para isso vidas tenham que ser sacrificadas. No romance de Saramago, é o Diabo que insiste no respeito pela vida, enquanto Deus se delicia com a morte. Delineia-se, assim, a enorme contradição que permeia as escrituras sagradas: para agradar a Deus é necessário tirar uma vida, neste caso a de uma ovelha, mas poderia ser a de um homem, como ocorre várias vezes nos escritos do Antigo Testamento, caso que o romancista faz questão de mencionar, como podemos ver em outros trechos de $O$ Evangelho Segundo Jesus Cristo. A pergunta que parece se apresentar ao leitor e a de que se foi Deus que criou os seres vivos, por que razão ele deveria se comprazer com a morte prematura dos seres que criou. Estamos diante de uma das contradições existentes nos textos bíblicos que Saramago revisita em seu romance. Os evangelhos, apresentados como os textos sagrados que relatam a história do filho de Deus, apresentam-se como uma "verdade absoluta”, a palavra divina não admite questionamentos. A releitura da história de Jesus, realizada no romance, procura relativizar essa "verdade”, colocando em foco as contradições inerentes ao próprio texto bíblico e as crenças religiosas originadas a partir dele. O herói, levado ao centro da narrativa, parece ter como função mostrar, através de seu percurso no universo romanesco, o caráter obscuro da ideologia religiosa que predomina, não apenas na sociedade existente no início da era cristão, da qual faz parte, mas que se estende até o presente do discurso, servindo como justificativa para os mais diversos tipos de crueldade cometidos pelo ser humano no decorrer da história. 


\section{Maria de Magdala e Jesus}

Como já vimos acima, em seu livro O código dos códigos, Frye aponta para o fato de que os românticos procuraram recuperar personagens renegadas pela tradição judaico-cristã entre as quais encontramos o próprio Lúcifer $^{44}$. Esse, segundo a tradição cristã, era no princípio dos tempos o preferido de Deus, que por almejar o lugar de seu criador acabou sendo expulso dos céus e a ele e a seus anjos (os demônios que o apoiaram em sua rebelião contra Deus) são computados os males da humanidade. Acima, já pudemos perceber o modo como o Diabo, apresentado como Pastor (designação normalmente dada no texto bíblico à figura de Deus ${ }^{45}$ ), é tratado pelo romancista. Os papéis se invertem e o anjo caído é quem defende a vida, enquanto Deus se diverte com o derramamento de sangue, como no caso da morte da ovelha. Assim como Lúcifer, Maria de Magdala é outra personagem bíblica renegada pela tradição cristã. Durante muito tempo, ela ficou conhecida pela cultura popular como aquela que tentou Cristo em seu sagrado caminho para o sacrifício no calvário e, conseqüentemente, transformou-se em um símbolo de mulher decadente. No final do século XI, por exemplo, desenvolveu-se um culto à figura de Maria Madalena, que induzia a associação de sua imagem à das prostitutas ${ }^{46}$, cuja redenção só era possível mediante muita penitência.

Em boa parte das obras referidas na primeira parte dessa dissertação, podemos notar uma certa recuperação da imagem de Maria. Em A vida de Jesus, de Ernesto Renan, Maria de Magdala é considerada a mais importante das mulheres que acompanharam Jesus em suas andanças, tendo desempenhado um papel relevante para o estabelecimento da fé na ressurreição:

\footnotetext{
${ }^{44}$ Segundo Frye, o "movimento romântico trouxe uma renovação, em ampla escala, envolvendo simpatia por essas figuras bíblicas rejeitadas e quase trágicas, podendo ter de partir para o exílio mas sendo, em outro contexto, os herdeiros devidos. Caim, Ismael, Esaú, Saul, até o próprio Lúcifer são todos heróis românticos. O significado e a importância disso têm em parte relação com as mudanças ocorridas no desenho do universo mitológico derivado da Bíblia pela Cultura Ocidental (...)” (FRYE, 2004, p. 219).

${ }^{45}$ Como exemplo, podemos citar o Salmo 23, intitulado na Bíblia de Jerusalém como “O bom Pastor”. O primeiro versículo diz o seguinte: "Iahweh é meu pastor, nada me falta”, onde Iahweh é uma das denominações dadas a Deus no Antigo Testamento.

46 "O desenvolvimento do culto de Maria Madalena e de Maria Egipcíaca, a partir do fim do século XI induzia à associação das mulheres perdidas a estas santas sendo aquelas levadas a reviver a mesma experiência de conversão e de penitência (...)” (PILOSU, 1995, p. 97).
} 
Uma delas, Maria de Magdala, que tão soado fez no mundo o nome de sua pobre aldeia, parece que foi muito exaltada. Segundo a linguagem do tempo tinha sido possuída de sete demônios, isto é, tinha sido acometida por moléstias nervosas e aparentemente inexplicáveis. Jesus, pela sua beleza pura e suave acalmou aquela organização agitada. A Madalena foi-lhe fiel até ao Gólgota, e desempenhou um papel de primeira ordem dois dias depois de sua morte, porque foi ela o órgão principal pelo qual se estabeleceu a fé na ressurreição (RENAN, 1926, p. 133).

A ressurreição é, talvez, o evento mais importante para a fé cristã. Deste modo, parece-nos que Renan recupera a personagem, antes uma reles pecadora, atribuindo-lhe uma importância crucial para a história cristã, de modo que ela é tão ou até mais importante quanto a outra Maria, a de Nazaré, a quem a tradição cristã atribui o papel de mãe virgem do filho de Deus, fato que Renan não admite como verídico na sua releitura da vida de Jesus.

Na esteira de Renan seguem escritores como Gattina e Eça de Queiroz que, de um modo ou de outro, acabam recuperando a imagem de Maria de Magdala. Em Memórias de Judas, de Gattina, ela é a mais fiel seguidora de Jesus e ao lado de Judas Iscariotes é a única a apoiá-lo no seu pior momento que foi o da crucificação, quando todos os outros discípulos abandonaram seu mestre. É, como em Renan, ela que apresenta motivos para crença da ressurreição ao anunciar que o corpo de Jesus havia desaparecido do túmulo ${ }^{47}$, nesse romance que, como já vimos, o filho de José não morreu no momento da crucificação, mas três anos depois na capital do Império, onde vivia na companhia de Judas. Em A Relíquia, de Eça de Queiroz, certamente influenciado por Renan, atribui à Maria de Magdalaa responsabilidade pelo mito da ressurreição, como já vimos acima, em que ao encontrar o túmulo de Jesus vazio, movida pelo amor a seu mestre, sai a declarar que este ressuscitara.

Em A Última Tentação de Cristo (1951), de Kazantzakis, Maria tem um papel de suma importância para narrativa, uma vez que ela é o motivo central da tentação de Cristo durante todo romance. Como já vimos, Jesus quer abandonar seu papel como messias para casar-se com Madalena, que também é sua prima. Neste romance, parece-nos que Maria assume, por um lado, o papel da mulher decadente atribuído a ela pela tradição cristã só recuperável por meio de muita penitência, mas por outro lado, ela pode ser vista como uma injustiçada, que foi cruelmente afastada do homem que amava pela intervenção divina.

\footnotetext{
47 "Maria esteve sublime até o fim. No dia seguinte ela propalou a notícia entre os discípulos do rabino que este havia ressuscitado" (GATTINA, 1946, p. 362). Neste romance, Maria é uma das arquitetas da farsa que originará o mito da ressurreição de Cristo. Ela participou do resgate de Jesus ainda vivo, após a crucificação, ao lado de Judas Iscariotes, o narrador-personagem do romance, e de Lêntulo, jardineiro de José de Arimatéia e se encarregou de espalhar a notícia de que ele havia ressuscitado.
} 
É interessante lembrar, que nos textos bíblicos a relação sexual é, com raras exceções, vista apenas como uma forma de procriação e, neste caso, o papel da mulher se restringe ao sagrado dever de ter filhos, tudo que passar disto é um ato de pecado contra a religião. Segundo Pilosu, o

principal papel que a Mulher (Eva) tem no Antigo Testamento é o de instrumentum diaboli, um instrumento que causa a perdição do gênero humano, resgatado depois pela descida do Salvador. O motif da tentação da carne personificada por uma representante do sexo feminino aparece desde as primeiras páginas do Gênesis e constituirá o próprio núcleo da religião mosaica, de maneira que o topos da mulher enquanto instrumento diabólico será uma componente sempre presente na religião judaica e, depois, na cristã (1995, p. 29).

Como Salvador da humanidade, o Jesus dos evangelhos sempre esteve acima destas questões humanas, não há registro nesses textos bíblicos de que o herói tenha se aproximado de uma mulher com o interesse de ter relações com ela, ou sequer se menciona que ele as desejasse. Em sua releitura da história de Cristo, Renan, embora mencione que as mulheres acolhessem Jesus de modo caloroso ${ }^{48}$, não se atreve a dizer que ele tenha passado da relação de mestre com alguma delas. Em Gattina, encontramos uma Maria de Magdala muito atenciosa com seu mestre ${ }^{49}$, mas também não há indícios de que tenham sido amantes, Jesus recebe a mesma atenção calorosa por parte de uma mulher, tal como em Renan. Topsius, personagem de A Relíquia, vê Maria como uma mulher apaixonada por Jesus, mas também não sabemos se ela era correspondida. É em A Última Tentação de Cristo, dentre as obras vistas na primeira parte deste trabalho, que se toca diretamente na questão da vida sexual de Jesus, cuja relação com Maria, a “última tentação”, irá se consumar apenas em sonho, pois em vida se caracterizará como tabu, que atormenta o herói até o seu último momento. Já em $O$ Evangelho Segundo Jesus Cristo, não se trata mais de um sonho, pois o herói da narrativa tem em Maria de Magdala mais do que uma seguidora fiel e apaixonada: ela é também sua amante e, algumas vezes, conselheira que o influenciará em momentos cruciais da narrativa, como é o

\footnotetext{
48 "Com efeito, as mulheres acolhiam-no com entusiasmo. Jesus empregava para com elas aquelas maneiras reservadas que tornam possível uma dulcíssima união de idéias entre os dois sexos. A separação dos homens e das mulheres, que entre os povos semíticos estorvava o desenvolvimento de sentimentos delicados, era sem dúvida, então como hoje, muito menos rigorosa nos campos e nas aldeias do que nas grandes cidades. Três ou quatro galiléias dedicadas acompanhavam sempre o mestre, e disputavam umas as outras o prazer de ouvi-lo e tratá-lo com desvelo. Introduziam na nova seita um elemento de entusiasmo e de maravilhoso, cujo grau de importância já medimos” (RENAN, 1921, p. 122).

49 "Além disso Magdala atraía-o [a Jesus]. Era um outro Tântalo dessa casa pequena e asseada, onde Maria o cercava de atenções e carícias e tinha fé nele” (GATTINA, 1946, p. 210).
} 
caso do episódio que poderíamos chamar de a não-ressurreição de Lázaro, que comentaremos mais adiante.

A relação sexual no romance de Saramago entre Jesus e Maria de Magdala tem como objetivo central o prazer negado o tempo todo ao homem no texto bíblico, pois o único “prazer” que lhe é permitido consiste na adoração a Deus, o amor carnal, como já vimos, se não for como forma de procriação, é um pecado, passível de punição. O narrador de $O$ Evangelho Segundo Jesus Cristo nos faz perceber a relação amorosa como algo importante para a vida da personagem e, portanto, despida de qualquer mal que se poderia atribuir a tal ato, pois se trata de um aprendizado que antes de tudo significa "liberdade”:

Durante todo o dia, Maria de Magdala serviu e ensinou o rapaz de Nazaré que, não a conhecendo nem de bem, nem de mal, lhe viera pedir que o aliviasse das dores e curasse das chagas que, mas isso não o sabia ela, tinham nascido doutro encontro, no deserto com Deus. Deus dissera a Jesus, A partir de hoje pertences-me pelo sangue, o Demônio, se o era, desprezara-o, Não aprendeste nada, vai-te, e Maria de Magdala, com os seios escorrendo suor, os cabelos soltos que parecem deitar fumo, a boca túmida, olhos como de água negra, Não te prenderás a mim pelo que te ensinei, mas fica comigo esta noite. E Jesus, sobre ela, respondeu, O que me ensinas, não é prisão, é liberdade (SARAMAGO, 2001, p. 283-4).

Como podemos perceber, flagelado por Deus e rejeitado pelo Diabo, Jesus só irá encontrar consolo nos braços de uma prostituta, mulher colocada à margem da sociedade, como símbolo de decadência e perdição. Porém, depois de se deparar com um Deus cruel, impiedoso e indiferente às necessidades humanas, é no contato com uma mulher "perdida" que o herói da narrativa encontra um sentimento sublime que, antes de tudo, liberta: o amor de uma mulher. A figura da prostituta, aceita pela tradição cristã apenas depois da contrição e penitência, ganha um maior status no romance, pois aquilo que ela tem a oferecer é muito mais importante que a submissão a vontade divina.

Jesus e Maria de Magdala formam um casal ilegítimo aos olhos da religião, tipo de relação que aparece em outros romances de Saramago e é sempre valorizado pelo romancista. Em Memorial do Convento, temos a relação de Baltasar e Blimunda, que se unem sem serem casados. O que caracteriza este casal é a total indiferença pelas regras sociais e religiosas que impõem limites a este tipo de relacionamento. Segundo Cerdeira da Silva, a relação entre Baltasar e Blimunda é

de natureza fundamentalmente transgressora: não são casados pelas leis sacramentais (...), não procriam entregam-se com freqüência às carícias e aos jogos eróticos, sem levarem em 
conta limites desejáveis, lugares reservados ou datas prescritas para a abstinência. Estão absolutamente fora dos códigos, numa amoralidade que derruba os interditos pelo simples fato de não os levarem em consideração. Vivem um encontro despojado de regras, que escapa ao controlo eclesiástico da penitência pela não introjecção da culpa, que resulta na ausência de necessidade de confissão (CERDEIRA DA SILVA, 1989, p. 82).

Parece-nos que o mesmo ocorre com a relação entre Jesus e Maria de Magdala, eles não só não estão casados, como também podemos considerar o fato de Maria de Magdala ser uma prostituta. No entanto o ato sexual deles é, dentro da narrativa, talvez o momento mais sublime semelhante ao que ocorre em Memorial do Convento, em que o ato sexual entre Baltasar e Blimunda é, de certa forma, sacralizado. Segundo Sant’Anna, nesse romance, a

narrativa sublima o ato sexual, elevando Baltasar e Blimunda a plena comunhão de corpos naquele instante assemelhados, na inocência do estado de pureza original, ao primeiro casal edênico Adão e Eva, pois estavam igualmente nus -, e reproduzindo com o sangue da virgindade de Blimunda a virtuosidade do cristianismo representado na cruz que ela desenha no peito de Baltasar: é o símbolo da simbiose do casal, em abençoada "transubstanciação amorosa. Os dedos indicador e médio com que Blimunda desenha o símbolo cristão no peito de Baltasar e o ato de persignar-se ao fazê-lo reproduzem o procedimento gestual do sacerdote na ministração da benção (...) e reforçam na narrativa a intenção de elevar ao nível do sagrado a humana virgindade que ela consagrou para dentro do coração do amado (SANT’ANNA, 2005, p. 147).

A partir dessa análise, podemos perceber que o ato sexual entre Baltasar e Blimunda, que para tradição cristã seria algo pecaminoso uma vez que os dois não são casados e, portanto, não possuem o aval religioso, é sublimado no romance de Saramago e se trata de um momento sagrado. Parece-nos que a iniciação sexual de Jesus, em O Evangelho Segundo Jesus Cristo, segue a mesma tendência. O episódio do sacrifício da ovelha, em que Jesus se encontra com Deus no deserto, é recheado de ironia e sarcasmo, em que encontramos um Deus ávido por sangue, pelo qual o narrador não parece ter nem de perto o mesmo respeito demonstrado no Êxodo, na primeira vez que Moisés se encontra com Deus, representado pela sarça ardente, que mesmo em chamas não se consumia ${ }^{50}$ : Jesus está sem sandálias, mas não porque o chão que pisa é sagrado, nem por estar diante da presença divina, mas simplesmente porque seu calçado se estragou durante a caminhada. O encontro com Maria de Magdala e sua

\footnotetext{
${ }^{50}$ Em Ex. 3: 1-6: “Apascentava Moisés o rebanho de Jetro, seu sogro, sacerdote de Madiã. Conduziu as ovelhas para além do deserto e chegou ao Horeb, a montanha de Deus. O Anjo de Iahweh lhe apareceu numa chama de fogo, do meio de uma sarça. Moisés olhou e eis que a sarça ardia no fogo, e a sarça não se consumia. Então disse Moisés: 'Darei uma volta e verei este fenômeno estranho; verei por que a sarça não se consome'. Viu Iahweh que ele deu uma volta para ver. E Deus o chamou do meio da sarça. Disse: 'Moisés, Moisés'. Este respondeu: 'Eis-me aqui'. Ele disse: 'Não te aproximes daqui; tira as sandálias dos pés porque o lugar que pisas é terra santa’”.
} 
relação com ela, por outro lado, é um momento sublime na narrativa, em que o herói tem as suas feridas curadas e aprende a conhecer a si mesmo e ao outro. A narrativa do primeiro ato sexual do herói é intercalada por passagens de Cânticos dos Cânticos, livro bíblico atribuído ao rei Salomão. E toda cena se dá como se seguisse um ritual de aprendizagem, a continuidade do processo que Jesus passou a lado de Pastor, em que se valoriza a vida humana, fato que finalmente o herói da narrativa consegue compreender:

Não aprendeste nada, vai-te, dissera Pastor, e quiçá quisesse dizer que ele não aprendera a defender a vida. Agora Maria de Magdala ensinara-lhe, Aprende o meu corpo, e repetia, mas doutra maneira, mudando-lhe uma palavra, Aprende o teu corpo (SARAMAGO, 2001, p. 283).

Na casa de Magdala, pouco antes de sua relação com Maria, o jovem Jesus recorre a várias citações das escrituras que condenam a relação com uma prostituta. Em seu íntimo ainda surgem resquícios de sua educação religiosa, o tabu a ser superado, mas que parecem ser totalmente apagados depois que a relação é consumada:

A mulher reapareceu com um pequeno boião e vinha a sorrir como se alguém, dentro de casa, lhe tivesse contado uma história divertida. Jesus via-a aproximar-se, mas, se os olhos o não estavam enganando, ela vinha muito devagar, como acontece às vezes nos sonhos, a túnica movia-se, ondulava, modelando ao andar o balanço rítmico das coxas, e os cabelos pretos da mulher, soltos, dançavam-lhe sobre os ombros como o vento faz às espigas da seara. Não havia dúvida, a túnica mesmo para um leigo, era de prostituta, o corpo de bailarina, o riso de mulher leviana. Jesus, em aflição, pediu à sua memória que o socorresse com algumas apropriadas máximas do seu célebre homônimo e autor, Jesus, filho de Sira, e a memória serviu-o bem, murmurando-lhe discretamente, do lado de dentro do ouvido, Foge do encontro de uma mulher leviana, para não caíres nas suas ciladas, e logo, Não andes muito com uma bailarina, não suceda que pereças por causa dos seus encantos, e finalmente, Nunca te entregues á prostitutas, para que não te percas a ti e a teus haveres (SARAMAGO, 2001, p. 279)

Como podemos perceber, a iniciação sexual de Jesus é precedida de uma série de conflitos de um adolescente educado pela tradição talmúdica, conforme observa Sant’Anna, segundo o qual é necessário para que a personagem supere o tabu a

intervenção de um elemento externo que o conduza ao rompimento das proibições do tabu sexual no campo das repressões religiosas que a produziram. Maria, pois, apresentar-se-á como o instrumento duplamente eficaz para romper a força do tabu: o encantamento que a sua beleza exerce sobre Jesus e a ritualização eucarística que ela faz do ato sexual (SANT'ANNA, 2005, p. 155).

Podemos notar, dessa forma, a importância de Maria de Magdala para a formação da personagem Jesus em O Evangelho Segundo Jesus Cristo. Ela não apenas o ajuda a superar o 
tabu sexual, mas faz com que ele veja o mundo de outra maneira, de modo que ele consegue compreender até mesmo o que Pastor quisera lhe ensinar, a valorização da vida. É a partir desse momento que a personagem Jesus toma outro rumo dentro da narrativa: ele adquire um outro tipo de consciência diferente daquela baseada na fé religiosa pura e simples e que mais tarde o fará questionar seu próprio destino e enfrentar abertamente a Deus.

Após o encontro com Maria de Magdala, Jesus retorna para a casa de sua família em Nazaré. Seu desejo era contar para sua mãe e irmãos sobre o seu encontro com Deus, no que é desacreditado. A resposta que lhe deu seu irmão Tiago traduz o mesmo preconceito que é atribuído pela tradição cristã aos judeus que crucificaram Jesus: “Ofendes o Senhor, o Senhor fez uma aliança com o seu povo, não a ia fazer agora com um simples homem como tu, filho de carpinteiro, pastor e sabe-se lá que mais” (SARAMAGO, 2001, p. 301). É fácil de perceber que a idéia de que Deus, o criador do universo, teria feito aliança com um reles carpinteiro não poderia passar pela cabeça nem mesmo da família de Jesus, uma vez que eles estavam cientes da situação de penúria em que sempre viveram, nem mesmo sua mãe, Maria, creu nele, o inverso do que ocorre nos textos bíblicos, em que ela está ciente do destino reservado a seu filho. A família de Jesus não vê nele nada de especial que os fizesse acreditar no que ele lhes dizia. Diante disso o filho de José abandona novamente a sua casa para nunca mais voltar:

Por segunda vez, Jesus saía de sua casa, mas agora não disse, Duma maneira ou doutra, sempre voltarei. O que pensava, enquanto, voltadas as costas a Nazaré, ia descendo a primeira encosta da montanha, era bem mais simples e melancólico, se também Maria de Magdala não acreditaria nele (SARAMAGO, 2001, p. 303).

Jesus sente-se magoado pelo fato de sua família não lhe ter dado nenhum crédito pelo que dizia. E, abandonando a "sagrada família” ele encontra apoio justamente em quem menos deveria esperar, como preconceituosamente, poder-se deduzir. A partir disso, Jesus passa a viver com Maria de Magdala. É neste momento que parece haver uma transição no romance, a personagem principal passa definitivamente da adolescência para a fase adulta:

Trabalho, Jesus não teve, mas teve o que deveria ter esperado, risos, chufas e insultos, realmente o caso não era para menos, pouco mais do que adolescente na idade, a viver com Maria de Magdala, aquela gaja, Deixem vocês passar uns dias e ainda o vamos ver sentado à porta de casa, à espera que saia o cliente. Duas semanas se aguentou a troça, mas ao cabo Jesus disse a Maria, Vou-me embora daqui, Para onde, Para a borda do mar. Partiram de madrugada e os habitantes de Magdala não chegaram a tempo de aproveitar alguma coisa da casa que ardia (SARAMAGO, 2001, p. 310). 
O período em que Jesus passa ao lado do Pastor e sua relação com Maria de Magdala parece-nos relevante para caracterização do herói, que se modifica no decorrer do romance, saindo de uma visão acrítica da sociedade religiosa da qual faz parte, para uma visão questionadora da realidade. É neste período que sua formação religiosa típica de seus compatriotas judeus, vai sendo desconstruída e dando lugar a uma tomada de consciência por parte da personagem, que se abre aos questionamentos a "verdade revelada", que passa a ser relativizada, e aos poucos o filho de Maria passa a perceber as contradições inerentes à religião de seus pais, na qual foi educado. E, mediante este processo, que ele passará a ser um defensor da humanidade, como herói deste evangelho escrito in nomine hominis. 


\section{Os últimos anos da vida de Jesus}

Os últimos anos da vida de Jesus, que correspondem a sua carreira terrena como o messias enviado por Deus, é, como já vimos, o que mais interessa aos evangelhos bíblicos. A maior parte dessas narrativas é dedicada para a narração dos ditos e feitos do filho de Deus, que irão culminar com os eventos principais da história cristã: a morte e ressurreição de Cristo. Estes acontecimentos cruciais na história da redenção do homem surgem como forma de resgatar o homem do pecado original através do sacrifício do filho de Deus. Cada evangelista narra estes eventos a sua maneira, de acordo com um ponto de vista peculiar, de modo que temos narrativas discordantes entre si sobre a mesma história dentro do cânone cristão. Como já dissemos, é esta variedade de versões dentro do próprio cânone cristão, bem como outros textos sobre Jesus não aceitos no cânone, que inspiraram os diversos autores a que nos referimos nesse trabalho a revisitar a história de Jesus.

A carreira de Jesus como messias começa nos evangelhos sinópticos após o batismo e a tentação no deserto. O batismo pode ser visto como um rito iniciatório ${ }^{51}$, em que o herói da narrativa, mediante esse "novo nascimento", vê-se pronto para iniciar sua missão para a salvação do gênero humano. Por outro lado, no evangelho de João o ministério terrestre tem como marco inicial o milagre do vinho nas bodas de Cana, que segundo Kermode "é um limiar; ele corresponde à história da Tentação contada nos sinópticos, mas não em João. Em um momento da história que ainda não chegou, como ele diz à sua mãe; então, abruptamente, ela chega" (KERMODE, 1997, p. 453). Esse início tão importante para o Evangelho de João ganha outro colorido nas releituras heterodoxas vistas na primeira parte desse trabalho, nas obras em que o episódio é citado como em Memórias de Judas, A Última Tentação de Cristo e no próprio Evangelho Segundo Jesus Cristo, o evento já não tem o mesmo sentido de marco inicial dos evangelhos, mas ganha significados próprios em cada uma dessas narrativas. No romance de Gattina, por exemplo, Jesus Barrabás, tio de Jesus, faz pouco caso desse episódio, apresentando seu sobrinho como um hábil trapaceiro:

\footnotetext{
${ }^{51}$ Segundo Eliade, os mitos e ritos iniciatórios preparam um novo nascimento, um retorno à origem, que não corresponde a um nascimento físico, mas uma renascença mística de ordem espiritual. "A idéia fundamental é que, para ter acesso a um modo superior de existência, é preciso repetir a gestação e o nascimento, que são porém repetidos ritualmente, simbolicamente; em outros termos, as ações são aqui orientadas para os valores do Espírito e não para os comportamentos da atividade psicofisiológica (ELIADE, 2004, p. 76). O batismo de Jesus estabelece um modelo para a cultura cristã semelhante ao rito iniciatório semelhante ao descrito por Eliade.
} 
Olá, exclamou ele, meu sobrinho! Oh! É magnífico. Vais fazer algum milagrezinho como em Canaã, não é assim elegante sobrinho? Não sois capaz de imaginar que este maganão fez acreditar a uma súcia de bêbados no fim de um jantar de núpcias? Que bebiam vinho, nada mais que vinho, entretanto, só lhes dava a beber água tingida de vermelho pela beterraba! (GATTINA, 1946, p. 249).

O limiar da história para o Evangelho de João adquire, como vemos, outro significado na citação acima: é apenas um caso vulgar, que indica características marcantes de Jesus que serão repetidas no romance. Ironicamente, no romance de Gattina, o filho de Maria não é mais que um homem com idéias que deixavam pouco confortáveis seus contemporâneos mais instruídos e que se deixou manipular num jogo de poder por Judas Iscariotes. Em A Última Tentação de Cristo, Caná é um marco do drama de Jesus que fica impedido, por intervenção divina, de unir-se a Maria Madalena, com quem queria se casar. Em O Evangelho Segundo Jesus Cristo, o milagre das bodas de Caná é apenas mais um para os quais Jesus não tem explicação uma vez que ainda não sabe exatamente qual são os planos que Deus tem para com ele.

Jesus começa suas andanças como pregador, nas releituras heterodoxas que vimos até aqui, de modos distintos dos textos bíblicos. Parece-nos que para essas narrativas, o sentido do ministério terreno de Jesus não difere daquele próprio narrativa original, em que o "Reino de Deus” deveria ser anunciado. Nessas narrativas, Jesus aparece em segundo plano, como no romance de Gattina, em que Judas é a personagem principal da narrativa; é ridicularizado como em A Relíquia, de Eça de Queiroz, em que seu zelo pelo Templo é visto como a ação de um fanático religioso; tem seus dramas mais íntimos expostos como em A Última Tentação de Cristo e mesmo quando se apresenta de modo semelhante ao Cristo evangélico, como acontece na peça Jesus Cristo em Lisboa, de Raul Brandão e Teixeira de Pascoaes, o ambiente que o cerca é crivado pela ironia de tal forma que ele já não parece mais tal qual o apresentado pela tradição cristã. O batismo, no romance de Kazantzakis, por exemplo, não é o marco inicial da vida de Jesus como o messias, mas uma mudança no rumo de sua pregação. O Cristo do romancista grego, ao contrário do bíblico, sempre muito confuso com relação ao que devia fazer para agradar a uma divindade terrível e sempre muito temida, começa sua carreira pregando o amor fraternal: “Deus é amor”, um ponto de vista semelhante ao de Renan, em A Vida de Jesus: “O Deus de Jesus não é esse fatal superior que nos mata quando lhe apraz, que nos condena quando lhe apraz, que nos salva quando lhe apraz. O Deus de 
Jesus é nosso Pai. Ouvimo-lo quando escutamos um ligeiro sopro que grita em nós” (RENAN, 1926, p. 63). No entanto, após o batismo, o Cristo de Kazantzakis assume outra postura e, incentivado por João Batista, passa a exibir a ira de Deus perante a sociedade. Parece-nos que o mais relevante nessas narrativas não é exatamente o que Jesus pode fazer como filho de Deus, mas o que ele é enquanto indivíduo, seja o grande pensador, apresentado por Renan ou o problemático de Kazantzakis.

Assim, parece-nos que O Evangelho Segundo Jesus Cristo segue pelo mesmo caminho. O que seria o início para os Sinóticos um dos eventos mais importantes para o cristianismo, o batismo, desencadeia os episódios que levarão o filho de Maria a morte. No romance de Saramago, parece-nos que o fato realmente decisivo para o desfecho dessa versão da história de Jesus será a confabulação em meio ao Mar da Galiléia entre Jesus, o Diabo e Deus, quando o último revela a seu filho seus planos de expansão, e o papel que ele terá nesses planos. Em outras palavras, esse encontro é a revelação definitiva do papel que o filho de Maria desempenharia nos planos de expansão da nova religião que deveria surgir. É nesse momento que Jesus recebe as respostas que desejava para as inúmeras dúvidas que tinha em relação ao que ocorria em torno de si e o destino que lhe estava reservado. É relevante lembrarmos que o Jesus bíblico já conhecia seu destino desde o início da narrativa, era mister que ele cumprisse a profecia. Nas versões de Cristo de Renan, Gattina e Eça de Queiroz, completamente humanizadas, a morte de Jesus não é resultado de uma exigência divina, mas diz respeito a assuntos humanos, seja a condenação de um louco ou de alguém que não agradou o status quo. O Jesus de Raul Brandão e Teixeira de Pascoaes, em sua segunda vinda ao mundo, repete o mesmo trajeto de sua primeira estada e da mesma forma acaba por ser crucificado. O de Kazantzakis sabe qual é o seu destino e luta para driblá-lo, rendendo-se afinal a vontade inexorável de Deus.

Por outro lado, o Jesus de Saramago só toma conhecimento do que lhe irá ocorrer quando a narrativa do romance se aproxima de seu final. Depois de perceber a inutilidade de qualquer resistência diante de um poder que lhe é superior, o herói saramaguiano se rende pronunciando uma frase semelhante àquela de Maria quando o Anjo lhe traz a notícia de que ela será a mãe do filho de Deus: "Faça-se, então, em mim segundo a tua vontade" (SARAMAGO, 2001, p. 377). Essa frase, na boca de Maria no episódio da Anunciação em 
Lucas $^{52}$, significa aceitação pura e simples da vontade de Deus, que no texto bíblico representa a "verdade absoluta”. O mesmo não ocorre com o Jesus Saramaguiano, para quem tal resposta representa sua resignação diante de um fato incontestável: o herói não tem forças para fazer frente ao seu opressor.

É no Mar da Galiléia que o Deus saramaguiano se apresenta com todo seu $\operatorname{poder}^{53}$ e indiferença pela vida humana. Ele deseja deixar de ser adorado apenas por um pequeno povo do Mediterrâneo para expandir seus domínios a um número maior de adoradores. Para isso, como nos evangelhos bíblicos, Jesus deve se sacrificar, morrendo como escravo numa cruz, para assim fazer nascer a religião cristã: "E qual foi o papel que me destinaste no teu plano, $\mathrm{O}$ de mártir, meu filho, o de vítima, que é o que de melhor há para fazer espalhar uma crença e afervorar uma fé” (SARAMAGO, 2001, p. 370). Deus se refere ao sacrifício de Jesus de forma sarcástica. E essa indiferença que ele tem pelo sofrimento alheio, como já vimos no sacrifício da ovelha acima, em que se apresenta um ser egoísta e cruel, faz com que ele seja muito semelhante ao Deus decadente e corrupto de A velhice do Padre Eterno, de Guerra Junqueiro. É nas mãos desse Deus tirânico, sádico e manipulador que o Jesus de Saramago se encontra. E essa entidade divina que manipula o homem também está presente em outras narrativas como já vimos. Em Muerte de Ahaverus, o judeu errante se dá conta de que seu verdadeiro algoz é Deus e não Jesus como ele julgava. Em Kazantzakis, Deus é o próprio inimigo na visão das personagens.

Após seu primeiro encontro com Deus no deserto, o Jesus saramaguiano ciente de que podia realizar milagres, temia fazê-los, pois receava que seu "pai celeste” escarnecesse dele outra vez, tal qual fizera no deserto:

Mas Jesus não se decidia, tinha medo de que Deus escarnecesse dele, o humilhasse como no deserto fizera e podia ter feito depois, ainda hoje se sentia estremecer à lembrança da vergonha que teria sido, quando pela primeira vez disse Lançai a rede desse lado, vê-la subir vazia. Tanto o ocupavam estes pensamentos que uma noite sonhou que alguém lhe dizia ao ouvido, Não temas, lembra-te de que Deus precisa de ti, mas quando acordou teve

\footnotetext{
${ }^{52}$ Maria diz em resposta a notícia do Anjo: "Eu sou a serva do senhor; faça-se em mim segundo a tua palavra”. (Lc 1: 38)

${ }^{53}$ Segundo Krysinski, considerando uma declaração a posteriori de Saramago ${ }^{53}$ a respeito de $O$ Evangelho Segundo Jesus Cristo, Deus é compreendido pelo Saramago como "une structure de pouvoir, une superstructure de manipulation, un édifice d'inégalité. Ainsi, dans cette configuration, l'homme a une fonction sulbalterne et strictement utilitaire. Mais en même temps, c'est homme qui est créauteur de Dieu. Il est celui qui, par soumission, érige Dieu dans toute sa majesté. Saramago rende Dieu humain, trop humain. Il le fait descendre sur terre et, une fois l'aterrissage acomple, tout se passe entre les humains. Dieu incarne la plus forte pulsion de pouvoir, il est le ‘Deus absconditus', l'iceberg d’une realité en fait ‘trop' humaine” (1999, p. 403).
} 
dúvidas sobre a identidade do conselheiro, podia ser um anjo, dos muitos que andam a fazer os recados do Senhor, podia ser um demônio, dos outros tantos que a Satã servem para tudo (SARAMAGO, 2001, p. 234).

Podemos perceber que Jesus teme a Deus ao mesmo tempo em que sente vergonha da humilhação que poderia ter sofrido diante dos pescadores se não houvesse acontecido o milagre da pesca caso as redes que ele sugerira lançar mais uma vez voltassem vazias. Esse temor a Deus não é muito diferente daquele que sente o Jesus de Kazantzakis, por exemplo. Além disso, o filho de Maria, no romance de Saramago tem dúvidas sobre o que realmente acontece consigo, uma vez que não consegue distinguir quem lhe envia mensagens, se Deus ou o Diabo, é evidente o caráter paródico do romance em relação aos evangelhos bíblicos: o predomínio das sensações humanas em Jesus é evidente, numa inversão patente do Cristo bíblico que é completamente seguro de seus atos. Esse nunca se envergonha ou tem dúvidas e só parece sentir medo ou angústia nos momentos que antecedem a paixão, como podemos perceber na oração descrita pelo evangelista Lucas em que Jesus pede para que Deus afaste dele o perigo da morte, mas é, claro, que isto seguiria a vontade divina, fosse ela qual fosse, de modo que o herói bíblico se dispõe a continuar sua caminhada rumo ao martírio da cruz. Ao comentar o episódio da Paixão no evangelho de João, Kermode salienta que a figura de Jesus é monumentalmente estável, são as outras personagens que agonizam ao seu redor. Talvez aqui esteja uma das diferenças cruciais entre o Jesus bíblico e o saramaguiano. Enquanto o primeiro é marcado pela estabilidade, nada muda ou abala sua personalidade durante toda narrativa, o segundo é caracterizadamente instável, o seu ser está sempre em constante conflito com a realidade que o cerceia, o que faz com que a personagem tenha um perfil sempre inacabado. O mesmo acontece com o Cristo de Kazantzakis sempre envolvido numa luta monumental com sua natureza humana que se sobressai em quase toda narrativa, até mesmo no momento em que está no calvário, em que sonha como poderia ser a sua vida se fosse apenas um homem. Em releituras da história contada pelos evangelhos, como Gattina ou Eça de Queiroz, o filho de Maria aparece como um homem tresloucado, cujo comportamento acaba por levá-lo ao martírio na cruz, a diferença crucial dessas versões de Jesus em relação à de Saramago consiste no fato de que o filho de Maria é completamente humano. Já na peça de Raul Brandão e Teixeira de Pascoaes, em seu retorno ao mundo, Jesus, tal como em Dostoievski, é muito parecido com o dos evangelhos e seu caráter de perfeição, seu ideal de liberdade, é que acaba por levá-lo novamente à morte. 
No romance de Saramago, Jesus, após se encontrar com Deus no deserto, ficou na expectativa de um próximo encontro, onde lhe seria revelado seu papel nos planos divinos. Entrementes, começaram a ocorrer alguns milagres em torno do herói, que ele próprio não sabia explicar, como é o caso do milagre da pesca, em que Jesus, com o desejo de agradecer pela atenção que os pescadores lhe tinham dado no tempo em que esteve com eles, sugerelhes que lancem mais uma vez a rede no mar, algo que já haviam feito várias vezes sem nenhum resultado:

A pesca não tinha sido frutuosa, o fundo do barco estava pouco menos que vazio, e André disse, Mano, vamos para casa, que este dia já deu o que tinha a dar, Simão assentiu, Tens razão, mano, vamos lá. Enfiou os remos nos toletes e ia dar a primeira das remadas que os levariam à margem, quando Jesus, não creiamos que por inspiração ou pressentimento de marca maior, foi um modo apenas, ainda que inexplicável, de demonstrar sua gratidão, propôs que se fizessem três últimas tentativas, Quem sabe se o rebanho de peixes, conduzido pelo seu pastor terá vindo cá para o nosso lado. Simão riu (...) e para André, Lança lá a rede, se não se ganha, também não se perde, e André lançou a rede e a rede veio cheia. Arregalaram-se de espanto os olhos dos dois pescadores, mas o assombro transformou-se em portento e maravilha quando a rede lançada mais uma vez e outra ainda, voltou cheia duas vezes. (...) Perguntaram Simão e André como soubera ele que o peixe ali chegara de um momento para o outro, que olhar de lince se apercebera do movimento profundo das águas, e Jesus respondeu que não, que não sabia, fora apenas uma idéia, experimentar a sorte uma última vez antes de regressarem. Não tinham os dois irmãos motivos para duvidar, o acaso faz destes e outros milagres, mas Jesus dentro de si, estremeceu, e no silêncio da sua alma perguntou, Quem fez isto (SARAMAGO, 2001, p. 274-5).

O episódio acima se passa pouco depois de Jesus haver deixado o Pastor e partido em direção a Nazaré. Na viagem de volta à casa de sua família, em que a personagem vai sem muita pressa, pois pressente o que poderá acontecer quando se reencontrar os seus, Jesus pára nas margens do lago de Genesaré, onde passa a ganhar seu sustento ajudando os pescadores. Como podemos perceber, o milagre ocorrido se dá de uma forma puramente casual, que surpreende o próprio Jesus, “Quem fez isto”. O narrador nos mostra que a personagem não tinha nenhuma intenção de obrar tal coisa, o que ela procurava era apenas mostrar gratidão aos pescadores que o trouxeram em sua companhia. O milagre da pesca ocorre sem que o herói possa dar qualquer explicação. Os beneficiários do milagre nem instam muito em saber como aconteceu o fato de que de um momento para o outro suas redes estavam transbordando de peixes. O comentário irônico do narrador é “o acaso faz destes e outros milagres”.

O mesmo episódio é narrado pelo evangelista Lucas. Nesse evangelho, Jesus com autoridade manda que Simão lance a rede. Esse protesta que já haviam tentado a noite toda 
sem resultado algum, mas porque era uma ordem de Jesus lançou-a e viu-a voltar cheia de peixes:

Quando acabou de falar disse a Simão: "Faze-te ao largo; lançai vossas redes para a pesca”. Simão respondeu: "Mestre, trabalhamos a noite inteira sem nada apanhar; mas porque mandas, lançarei as redes”. Fizeram isso e apanharam tamanha quantidade de peixes que suas redes se rompiam. (...)

À vista disso, Simão Pedro atirou-se aos pés de Jesus, dizendo: “Afasta-te de mim, Senhor, porque sou pecador!” (Lc 5: 4-6; 8)

No texto bíblico ocorre o reconhecimento imediato da autoridade de Jesus como autor do milagre. Ao contrário do romance, Simão reconhece no filho de Maria um santo do qual nem pode se aproximar. Não há espaço para dúvidas aqui, Jesus sabe muito bem o que está fazendo e, por ter feito isso, é imediatamente reconhecido como santo, nada dos preâmbulos do narrador do romance, nos evangelhos bíblicos tudo é muito claro e segue um esquema de milagre freqüente na Bíblia hebraica e no Novo Testamento: um problema é apresentado a alguém que pode resolvê-lo, e uma vez executado o milagre, há o reconhecimento daqueles que foram beneficiados por esse milagre ${ }^{54}$. Assim, ao contrário do que ocorre na narrativa de Lucas, o Jesus saramaguiano não tem o reconhecimento imediato do "milagre” que realiza que, no final das contas, mais parece uma questão de sorte: o rapaz Jesus mandou lançar a rede que por acaso voltou cheia de peixes. A pergunta que Simão e Pedro fazem a Jesus, no romance, soa irônica, pois o narrador acaba por concluir que "o acaso faz destes e outros milagres”. É interessante notar que em sua releitura dos Evangelhos Sinóticos, Flusser afirma que a região de Cafarnaum em que Jesus costumava ficar com os seus discípulos tinha peixes em abundância. Desse ponto de vista não poderia haver nenhum milagre da pesca, uma vez que não havia falta do produto desejado. O milagre dos peixes se repetirá varias vezes em $O$ Evangelho Segundo Jesus Cristo sem que haja preocupação, ou se procure atestar que o realizador do milagre é o filho de Deus. Tudo que se sabe é que quando Jesus está por perto o resultado da pescaria é mais do que satisfatório, e, por isso, o rapaz será sempre requisitado e até mesmo disputado como companhia pelos pescadores do lago.

\footnotetext{
${ }^{54}$ É Crossan que apresenta esse esquema: “um tipo de 'história de milagre’ bastante comum na Bíblia hebraica, no Novo Testamento e em outras fontes literárias. Estas histórias possuem três elementos: (a) um problema que é encaminhado para uma pessoa que pode ajudar; (b) a resposta milagrosa ou 'sobre-humana' dessa pessoa; e (c) a remoção milagrosa do problema. Este tipo de relato costuma acabar com um comentário laudatório daqueles que foram salvos” (CROSSAN, 1994, p. 189).
} 
Como podemos perceber, a personagem central dos evangelhos bíblicos age sempre com a autoridade de um filho de Deus, superior em tudo aos demais homens. Já o herói do evangelho de Saramago é um indivíduo simples, rústico e sempre à busca de respostas, cercado de dúvidas e incertezas em relação ao seu próprio futuro. Mesmo que ocorram milagres em torno da pessoa do Jesus saramaguiano, ele nunca deixará de ser um homem, pois sua natureza humana é o que há de mais sagrado para ele. No final das contas, é Deus quem realiza os milagres por intermédio de Jesus, pois tem a intenção de criar um mito que ampliará o número de seus adoradores no mundo. Se o Jesus bíblico é desde o início da narrativa consciente do papel que lhe é reservado na história, o Jesus de Saramago tomará consciência do papel que lhe será imposto por Deus nos seus planos de conquista. Uma diferença relevante de um para o outro é que o primeiro confunde-se com o próprio Deus e o segundo é imediatamente colocado em oposição a esse Deus, inimigo da humanidade.

Como vemos, Jesus passa a realizar milagres, pois se dá conta que isso é possível, porém, tais feitos vão despertando nele dúvidas e incertezas, pois desconfia de qual serão os planos de Deus para com ele, antevendo a catástrofe de sua vida:

e ali estava ele, Jesus, o homem que gritara, o que ordenava os peixes que saíssem das águas para os homens, o que ordenava às águas que não levassem os homens para os peixes. Jesus tinha se sentado no banco dos remadores, de cabeça baixa, com uma difusa e contraditória impressão de triunfo e de desastre, como se, tendo subido ao ponto mais alto duma montanha, no mesmo instante começasse a melancólica e inevitável descida (SARAMAGO, 2001, p. 336).

Os sentimentos da personagem saramaguiana apresentam a mistura de elementos contraditórios. O seu triunfo é limitado pelo pressentimento de que o herói inicia uma inevitável queda, algo de que ele terá certeza mais tarde quando souber que está envolvido em um plano que requer o sacrifício daqueles que o seguirem e que ele não poderá evitar tanta morte e sofrimento. Os milagres do Jesus bíblico são sempre motivo de júbilo, pois são a manifestação da glória de Deus no meio dos homens.

Ao voltarmos nossa atenção para o milagre da multiplicação dos pães, deparamos-nos com um bom exemplo da inversão paródica dos textos bíblicos que ocorre no romance de Saramago. Nos quatro evangelhos bíblicos o milagre se dá unicamente por iniciativa de Jesus. Esses podem divergir em alguns aspectos quanto ao relato, exceto neste: o de que Jesus estava no controle da situação. Nos três sinópticos, quando os discípulos se aproximam dele e falam da necessidade de alimentar a multidão, ele, com autoridade, diz o que fazer. No caso 
do evangelho de João, Jesus pergunta a Felipe como alimentar a multidão, mas o narrador deixa bem claro que a personagem principal da narrativa já tem a solução em mente. Ocorre exatamente o contrário no romance de Saramago, nele são os discípulos que tem que mostrar o caminho a Jesus:

\begin{abstract}
Jesus nem por sombras imaginava que pudesse valer a tanta gente num tal aperto, mas Tiago e João, com a segurança que caracteriza as testemunhas presenciais, foram para ele e disseram-lhe, Se foste capaz de fazer sair do corpo de um homem os demônios que o matavam, também deves poder fazer entrar no corpo dessa gente a comida de que precisam para viver, E como farei, se aqui não temos mais alimento do que este pouco que trouxemos, És o filho de Deus, podes fazê-lo (SARAMAGO, p. 360-1).
\end{abstract}

No romance, é necessário que Tiago e João encorajem Jesus, lembrando-lhe seu papel como filho de Deus, que souberam pela boca do próprio demônio, e os milagres que ele já havia feito como uma prova de que seria capaz de solucionar o problema com o qual se deparava, que era o de alimentar a multidão. A diferença entre os evangelhos bíblicos e o romance é clara. No primeiro caso são os discípulos que duvidam o tempo todo não crendo no poder de que se reveste a personagem principal como ser divino e que transcende os limites do caracterizadamente humano. John Drury comenta a falta de compreensão dos discípulos, no evangelho de Marcos, em relação ao significado dos feitos de Jesus. "Sendo as refeições miraculosas tão repletas de importância, a fúria controlada da inquirição de Jesus a seus discípulos no barco é compreensível e apropriada: 'Nem assim compreendeis?’ (8:21). Ele está desesperado. Eles não entenderam muita coisa. A discussão no trigal e o precedente davídico, a conversa animada com a mulher grega e as refeições miraculosas antes e depois disso - tudo se perdeu para eles. Mais do que isso, eles perderam de vista o sagrado e o divino, que, nesse longo fio de eventos codificados associados com o pão, se deslocou de seu contexto habitual para um novo lugar: da tradição antiga para a vida e corpo de Cristo, e a nova comunidade que será mantida por ele” (DRURY, 1997, p. 448). O significado muito mais extenso e abrangente dos milagres de Jesus que representam o sagrado e o divino na figura da personagem principal do evangelho não é compreendido pelos discípulos, pois lhes falta sabedoria para o entendimento dos desígnios de Deus, que só Jesus tem ao seu alcance.

Em contrapartida, o Jesus de Saramago é quem precisa de ajuda para crer no seu próprio potencial, os discípulos crêem no que ele pode realizar mais do que ele mesmo. Eles tiveram diante de seus olhos várias evidências do caráter sobrenatural de Jesus e isso aumenta a certeza deles do que Jesus é capaz. Porém, a própria personagem a quem são atribuídas tais 
capacidades sobre-humanas duvida de que realmente esse poder esteja depositado em si, se não é algo externo a ela. Como podemos perceber a figura do herói do romance é a inversa do bíblico. Se este é em si um ente completo não necessitando da interação com as outras personagens da história, o Jesus saramaguiano, não se forma de outra maneira: ele precisa interagir com os outros e aprender com eles, para dar seqüência ao papel que lhe está reservado em sua existência no mundo. Assim, o Jesus de Saramago aparece distanciado ironicamente do seu homônimo dos evangelhos bíblicos, a personagem principal do romance de Saramago precisa a todo o momento do auxílio das outras personagens com as quais irá se relacionar no decorrer da narrativa, o Pastor, a Maria de Magdala, os discípulos, ela sempre está em diálogo aberto com os outros integrantes da narrativa. E nisso, ele se assemelha novamente ao Jesus de Kazantzakis que sempre recebe o auxílio de Judas Iscariotes para seguir em sua caminhada. Aliás, como já vimos acima, o traidor, execrado pela tradição cristã, é colocado em um nível superior ao de Jesus, já que seu papel na economia da redenção é, ironicamente, o mais difícil, pois terá que trair o seu mestre e melhor amigo.

Depois do encontro de Jesus com Deus, O Evangelho Segundo Jesus Cristo se desenrola com mais rapidez até o seu desfecho trágico. A personagem passa a desempenhar por algum tempo o papel que lhe foi imposto por Deus sempre com a ajuda dos discípulos. O capítulo seguinte ao decisivo encontro no Mar da Galiléia se inicia com a parodização da proclamação feita por Jesus no Evangelho de Marcos, no momento em que Jesus inaugura seu ministério:

\footnotetext{
Depois que João foi preso, veio Jesus para a Galiléia proclamando o evangelho de Deus: "Cumpriu-se o tempo e o reino de Deus está próximo. Arrependei-vos e crede no Evangelho” (Mc, 1 14-15).

Jesus e os seus iam pelos caminhos e povoados, e Deus falava pela boca de Jesus, e eis o que dizia, Completou-se o tempo e o reino de Deus está perto, arrependei-vos e acreditai na boa nova (SARAMAGO, 2001, p. 401).
}

É interessante observarmos aqui que no romance não é Jesus quem fala, mas Deus que fala através dele. A partir do momento que passou a desempenhar seu papel nos planos divinos a personagem de Saramago tem seus atos vigiados por Deus, que faz de Jesus o uso que mais lhe convém. É possível percebermos uma conjunção de interesses entre Deus e a personagem principal dos evangelhos bíblicos, o que não ocorre no caso do romance, em que o herói é forçado a fazer aquilo que não deseja. O episódio do Sermão da Montanha, no 
romance de Saramago, parece deixar isso ainda mais claro, quando por um momento Deus se esquece do herói, esse passa a dizer ao povo palavras de esperança. Porém, quando Deus se dá conta do que está ocorrendo, não podendo reverter o que Jesus já havia dito faz com que ele pronuncie as palavras ameaçadoras de sempre:

E como, em sua maior parte, esta confiante gente provinha de baixos estratos sociais, artesãos e cavadores de enxada, pescadores e mulherzinhas, atreveu-se Jesus, num dia em que Deus o deixara mais a solta, a improvisar um discurso que arrebatou a todos os ouvintes, ali se tendo derramado lágrimas de alegria como só se conceberiam a vista duma já não esperada salvação, Bem-aventurados, disse Jesus, bem-aventurados vós, os pobres, porque vosso é o reino de Deus, bem-aventurados vós, os que agora tendes fome, porque sereis saciados, bem-aventurados vós, os que agora chorais, porque haveis de rir, mas nesta altura deu-se Deus conta do que ali estava a se passar, e, não podendo suprimir o que por Jesus tinha sido dito, forçou a língua dele a pronunciar umas outras palavras, com o que as lágrimas de felicidade se tornaram em negras lástimas por um futuro negro, Bemaventurados sereis quando os homens vos odiarem, quando vos expulsarem e rejeitarem o vosso nome infame, por causa do Filho do Homem (SARAMAGO, 2001, p. 404).

Como podemos ver, as bem-aventuranças são divididas em duas partes no romance. Na primeira parte, Jesus fala em um momento em que Deus afrouxa seus cuidados sobre ele e procura dar algum alento às pessoas mais pobres. Na segunda parte, forçado por Deus, Jesus pronuncia palavras com um sentido escatológico, a parte mais sombria das bem-aventuranças. As palavras de esperança de Jesus são seguidas pelas palavras cruéis que Deus obriga essa personagem dizer. Depois disso o filho de Maria se ajoelha e em silêncio pede perdão aos homens, pois não suporta a idéia de ser o instrumento que irá levar várias pessoas à morte. Os papéis são novamente invertidos, se na Bíblia são os homens que devem pedir perdão de seus pecados e Cristo tem o poder divino de perdoá-los, no romance é Jesus quem pede perdão, mesmo não sendo voluntariamente o culpado.

O episódio da não ressurreição de Lázaro parece ter um papel fundamental na última tentativa do herói do romance de se opor à vontade de Deus. No Evangelho de João a ressurreição de Lázaro tem um papel importantíssimo, pois acelera o desenrolar dos fatos até a crucificação de Jesus: é a partir do dia em que ocorre este milagre que os judeus resolvem matar Jesus, a "ressurreição de Lázaro não é, como incidentes comparáveis nos sinópticos, um evento isolado. Em João, ela é o grande pivô de seu enredo” (KERMODE,1997, 489). Em O Evangelho Segundo Jesus Cristo é depois da crise que a personagem enfrenta por não ter usado seu poder para ressuscitar Lázaro que ele decide tentar um último artifício para impedir que os planos de Deus dessem certos. 
Para Renan, como já vimos, o milagre da ressurreição de Lázaro pode ter sido uma forma que a família de Betania encontrou para ajudar um amigo. No romance de Gattina, esse milagre não passa de um simples despertar de um estado de catalepsia. Em A Última Tentação de Cristo, a ressurreição de Lázaro ganha uma versão cômica. Jesus ressuscita seu amigo, mas não consegue reverter à situação de decomposição em que o corpo do ex-morto se encontrava. Do modo como é descrito, o ressuscitado tem a aparência de um semimorto:

Jesus voltou ao pátio para poder respirar. Esse ressuscitado ainda hesitava entre a vida e a morte. Deus ainda não conseguira vencer o apodrecimento dentro dele. A morte jamais demonstrara sua verdadeira força tanto quanto no caso desse homem. Jesus foi dominado por um medo e por uma imensa tristeza (KAZANTZAKIS, 1998, p. 401).

$\mathrm{Na}$ citação acima, podemos perceber a ironia do narrador quando se refere à incapacidade divina diante da força da morte. E mais uma vez nesse romance encontramos um Jesus medroso e triste. Esse "milagre”, como nos evangelhos desperta a ira de líderes religiosos radicais que passam a maquinar contra Jesus. Por fim, Barrabás, orientado por Tiago, irmão de Jesus, mata Lázaro e só não mata o filho de Maria por esse estar sob a proteção de Judas Iscariotes.

Por outro lado, parece evidente que no evangelho de João, esse milagre tem como função mostrar o poder do qual Jesus é revestido. A doença de Lázaro é para a glória de Deus e há “a sugestão de que foi permitido que Lázaro morresse para este propósito” (KERMODE, 1997, p. 480). No romance de Saramago ocorre exatamente o contrário. Se até esse momento Deus vinha controlando os atos de Jesus, no caso de Lázaro, Jesus age por vontade própria, e, assim o cura de um mal logo que o conhece. Mas seu amigo enquanto ele vai a Jerusalém com o objetivo de expulsar os vendilhões do templo. Ao retornar de sua aventura, o herói encontra o irmão de Maria de Magdala morto e sofre muito com isso. Segue-se a isso as lamentações de Marta, tal como no texto bíblico em que ela observa que se Jesus ali estivesse, seu irmão não haveria morrido. No romance, esse episódio tem um novo desfecho, em que Jesus, de repente, sente uma força que não sentira em nenhum outro momento da história, passa acreditar que poderia fazer tudo:

Jesus levantou-se, sentiu que uma força infinita arrebatava o seu espírito, podia, nesta suprema hora, obrar tudo, cometer tudo, expulsar a morte deste corpo, fazer regressar a ele a existência plena, o ente pleno, a palavra, o gesto, o riso, a lágrima também, mas não a dor, podia dizer, Eu sou a ressurreição e a vida, quem crê em mim ainda que esteja morto viverá, e perguntaria a Marta, Crês tu nisto, e ela responderia, Sim, creio que és o filho de Deus que havia de vir ao mundo, ora, assim sendo, estando dispostas e ordenadas todas as 
coisas necessárias, a força e o poder e a vontade de os usar, só falta que Jesus, olhando o corpo abandonado pela alma, estenda para ele os braços como o caminho por onde ele há de regressar e diga, Lázaro, levanta-te, e Lázaro levantar-se-á porque Deus o quis, mas é nesse instante, em verdade último e derradeiro, que Maria de Magdala põe uma mão no ombro de Jesus e diz, Ninguém na vida teve tantos pecados que mereça morrer duas vezes, então Jesus deixou cair os braços e saiu para chorar (SARAMAGO, 2001, p. 428).

Nesse momento derradeiro da cena, Jesus parece se igualar ao seu homônimo bíblico, a descrição do episódio lembra claramente como os fatos se desenrolam no Evangelho de João. Em pensamento, o filho de Maria sente uma força que nunca antes havia sentido, e tal como o Cristo bíblico não duvida nem por um momento que pode dar novamente a vida a Lázaro, basta querer. Porém, tudo isso fica como num sonho, quando Maria de Magdala chama Jesus à realidade. Diante das palavras de sua companheira, "Ninguém na vida teve tantos pecados que mereça morrer duas vezes”, a o herói da narrativa perde toda a força que por um ínfimo momento tinha encontrado em seu interior e começa a chorar. A partir desse momento a personagem é tomada por uma dor incessante, constatando mais tarde que a morte é inevitável, de modo que decide morrer, mas de uma forma que poupe a vida dos outros, impedindo as mortes que deveriam ocorrer após a sua segundo a vontade de Deus.

Na narrativa bíblica, a paixão de Cristo tem como desfecho um final feliz. Jesus é crucificado, mas seu destino é vencer a morte e ressuscitar no terceiro dia e é isto que ocorre. O objetivo desse sacrifício é a remissão dos pecados da humanidade, que vêm desde do pecado original cometido pelo pai de todos os homens, Adão. No romance, a morte de Jesus tem um significado totalmente oposto, seu objetivo não é voltado para o bem do homem, mas para promover uma espécie de propaganda que faria ecoar o nome do Deus dos judeus para áreas maiores que um pequeno país à beira do Mediterrâneo. Jesus, como já dissemos, planeja atrapalhar este projeto de Deus, morrendo não como o filho dessa divindade, mas como um simples homem que se declarou o Rei dos Judeus, sendo este o seu crime. Seu plano não obtém sucesso, pois Deus no momento de sua morte intervem, declarando-o seu filho. Ao contrário do Cristo bíblico, o Jesus saramaguiano não ressuscita e seu fim é como o de todo homem: nascer, viver e morrer.

Tal como nas obras elencadas na primeira parte desse trabalho, o Jesus saramaguiano passa por um processo de desmitificação em relação ao seu homônimo bíblico. Porém, ao contrário do que ocorre nas obras do século XIX, em que ele é completamente desdivinizado, 
em O Evangelho Segundo Jesus Cristo, ele se mantém entre o divino e o humano em um contexto em que o humano passa a ser valorizado em relação ao divino.

É com os gregos, indianos e egípcios que se observa um primeiro movimento de desmitificação, tal como ocorre com o romance de Saramago, em que se procura desmitificar a história dos evangelhos, rebaixando sua personagem central a padrões mais humanos. No caso dos antigos, em determinado momento da história, uma elite perde o interesse pela história dos deuses e instauram assim um processo de desmitificação da cultura, embora ainda se pretenda acreditar nos deuses, os mitos são rebaixados à condição de lendas e contos infantis:

Para essas elites, o "essencial” não deveria ser procurado numa história dos deuses, mas numa "situação primordial" que precedeu essa história. Assistimos aqui a um esforço para ir além da mitologia enquanto história divina e de atingir a fonte primacial de onde jorrou o real, de identificar a matriz do Ser. Foi procurando a fonte, o princípio, a arché, que a especulação filosófica reencontrou, por um breve intervalo, a cosmogonia; não era mais, entretanto, o mito cosmogônico, mas um problema ontológico (ELIADE, 2004, p. 101).

A problemática que se apresenta em relação ao romance que estamos estudando, o tema da releitura do mito cristão trata, como vemos, também de uma desmitificação de um texto sagrado. O novo foco, o essencial, é o homem e a vida humana, em detrimento do espaço relegado à divindade cristã.

Desse modo, ao considerarmos os evangelhos como um mito que pretende recuperar as origens do cristianismo, narrando a história sagrada do Filho de Deus, podemos pensar o processo de desmitificação que ocorre em O Evangelho Segundo Jesus Cristo como resultado do fato de que o novo "evangelho" não pretende recuperar as origens do que quer que seja. O que ele faz, isto sim, é denunciar um futuro negro (que remete o leitor do romance ao lado negro da história cristã) resultante do nascimento do Cristianismo, que mais tarde será motivo para as guerras em nome do Deus cristão e para intolerância religiosa, em que se destacam respectivamente, as Cruzadas e a Inquisição.

Segundo Eliade, os primeiros cristãos não acreditavam estar apresentando um novo mito, mas utilizavam categorias do pensamento mítico. Assim, a repetição ritual do drama de Jesus e a imitação do modelo supremo baseado na vida de Cristo representam, a despeito do que pensavam os primeiros cristãos, um pensamento mítico autêntico. Ora, é esse modelo supremo, o Cristo crucificado, que o Jesus do heterônimo pessoano Alberto Caeiro rejeita no poema VIII de O Guardador de Rebanhos. É também factível que a desmitificação da figura 
de Jesus no romance de Saramago ocorre exatamente pela recusa desse modelo mítico proposto pelos evangelhos. No caso de O Evangelho Segundo Jesus Cristo, e da maioria das obras relacionadas nesse trabalho, Cristo não é mais um modelo a ser seguido, mas um homem com ambições humanas, que está em busca de algo, seja de autoconhecimento, seja de viver sua vida como um outro homem qualquer. O modelo divino é questionado, e Jesus é um homem, ou deseja desesperadamente viver como um homem, tendo que conviver com a imposição de uma natureza divina que não lhe convém e assim acaba tendo Deus por inimigo, como ocorre claramente no romance de Saramago ou em A Última Tentação de Cristo. O narrador de O Evangelho Segundo Jesus Cristo, quando retorna ao tempo primordial do cristianismo, rebaixa a natureza divina da personagem central do mito evangélico, enfatizando suas características humanas, como medo, raiva, entre outros atributos, desmitifcando assim o mito cristão. A releitura da vida de Cristo, tal como a que estamos estudando, dá-se a partir da perspectiva de existência profana em que “o homem só reconhece responsabilidade para consigo mesmo e para com a sociedade” (ELIADE, 2001, p. 83). Assim, a intenção do romance parece ser a de contar como o cristianismo passou a existir sob uma perspectiva totalmente profana, invertendo os princípios do sagrado existente na narrativa bíblica. O “por que" 55 da existência do Cristianismo não se apresenta mais como algo absolutamente necessário para a humanidade, mas como uma existência que poderia perfeitamente ser descartada: o próprio Jesus tenta fazer com que a religião cristã morra em seu nascedouro, pois na perspectiva da personagem, sabedora dos fatos que lhe sobreviriam, tal religião seria sanguinária para a humanidade. Assim, a natureza mítica do texto bíblico é evidentemente desconstruída pelo romance de Saramago, que parece instaurar um outros tipo de sagrado que é a própria existência humana. Assim, enquanto o "homem [religioso] só se torna verdadeiro homem conformando-se ao ensinamento dos mitos, imitando os deuses” (ELIADE, 2001, p. 89), o herói do romance de Saramago envereda por um outro caminho que o levará a oposição a Deus: Jesus advoga in nomine hominis, pois para ele o que mais importa, o realmente sagrado, é o próprio homem. Assim, onde o Jesus do Evangelista Lucas diz, no momento de sua crucificação, “Pai, perdoa-lhes: não sabem o que fazem” (Lc 23, 34), o Jesus

\footnotetext{
55 “Cada mito conta como uma realidade veio à existência, seja ela a realidade total, o Cosmos, ou apenas um fragmento: uma ilha, uma espécie vegetal, uma instituição humana. Narrando como vieram a existência às coisas, o homem explica-as e responde indiretamente a uma outra questão: por que elas vieram a existência? $\mathrm{O}$ “por que” insere-se sempre no "como”. E isto pela simples razão de que, ao se contar como uma coisa nasceu,
} 
de Saramago, diz, "Homens, perdoai-lhe, porque ele não sabe o que fez" (SARAMAGO, 2001, p. 444).

revela-se a irrupção do sagrado no mundo, causa última de toda existência real” (ELIADE, 2001, p. 86). 


\section{CONCLUSÃO}

Esta é a história do meu Menino Jesus.

Porque razão que se perceba

Não há de ser ela mais verdadeira

Que tudo quanto os filósofos pensam

E tudo quanto as religiões ensinam?

(VIII poema de $O$ Guardador de

Rebanhos, Fernando Pessoa)

Vimos na primeira metade dessa dissertação que a releitura predominante no século XIX procurava quase sempre mostrar um Jesus totalmente humanizado, numa clara tentativa de racionalizar a história contada pelos evangelhos. Isso acontece em A vida de Jesus, de Ernest Renan, em que o autor nos apresenta, não o Filho de Deus, mas um homem excepcional, cuja existência originou uma das mais belas histórias da humanidade; em Memórias de Judas, onde o filho de Maria não passa de um homem comum e de um religioso dos mais zelosos, cujas idéias são um pouco estranhas até mesmo para o narrador que o chama de "mau judeu”; e na Paixão de Cristo sonhada por Teodorico, em A Relíquia, onde o narrador personagem nos apresenta também um Jesus completamente humanizado. Nessa narrativa, a crucificação não passa de um acontecimento banal, que desperta o interesse dos poucos amigos de Jesus, que planejam reanimá-lo, empreita que não terá sucesso. Durante o episódio, o fato visível é, certamente, a conversa de Teodorico com o vendedor que havia perdido seus haveres quando Jesus expulsou os vendilhões do Templo. O rebaixamento de Cristo é nesse diálogo ainda mais contundente, pois ele não chega a ser nem o homem excepcional de Renan, pois mais parece com um fanático religioso, que no seu zelo excessivo acaba cometendo injustiças. No caso de Memórias de Judas vale ainda sublinhar que o narrador-personagem contesta o conteúdo dos evangelhos, que, segundo ele, não passam de meras falsificações da história feita pelos discípulos que sequer acreditavam em seu mestre. É factível nesses textos que seja pela tentativa de fazer uma leitura histórica da vida de Jesus, como faz Renan, ou através da elaboração de uma versão ficcional dessa história, como é o caso de Gattina e Eça de Queiroz, o resultado é sempre um Jesus despido de toda a sua divindade, distante de Deus que teve sua morte anunciada por poetas como, por exemplo, Gérard de Nerval, na poesia francesa, ou Antero de Quental, em Portugal.

É dentro do contexto dessa anunciada morte de Deus que vamos encontrar, em Guerra 
Junqueiro, a imagem do Deus cruel e impiedoso, rebaixado a imagem de um tirano, que aparecerá reiteradamente nas releituras do mito cristão no século $\mathrm{XX}$, como podemos ver em escritores como Pessoa, Kazantzakis, Pär Lagerkvist e no próprio Saramago. O Padre Eterno de Junqueiro é um ser corrupto e decadente, capaz de sacrificar o próprio filho para conseguir estender os seus domínios além dos limites do povo de Israel, idéia, aliás, utilizada em $O$ Evangelho Segundo Jesus Cristo, onde Deus planeja o sacrifício de Jesus para aumentar o número de seus adoradores. O Cristo do livro de Junqueiro é ridicularizado pelo poeta que o caracteriza como um idealista ingênuo, que não sabia o que estava realmente fazendo quando se deixou sacrificar.

Nas releituras do mito central do cristianismo feitas no século $\mathrm{XX}$, que vimos neste trabalho, Jesus recebe de volta sua divindade, mas não nos mesmos termos dos textos bíblicos. A história dos evangelhos continua sendo questionada, como no século anterior e mesmo nas obras onde Cristo reaparece como o ser divino da narrativa evangélica, o contexto em que ele é inserido contrasta difere muito daquele encontrado nos evangelhos canônicos. É o caso da peça Jesus Cristo em Lisboa, de Raul Brandão e Teixeira de Pascoaes. Nessa peça, Cristo volta ao mundo, segue um percurso semelhante ao dos evangelhos, falando aos pobres e realizando milagres, e é novamente condenado e crucificado, pois sua existência é intolerável para a humanidade, algo semelhante ao que ocorre em "O Grande Inquisidor”, de Dostoievski, em que Jesus volta ao mundo na época da Inquisição e é condenado como um herege, pois sua presença, na fala do grande Inquisidor, não é tolerável, pois estragaria os esforços que a Igreja Católica teve para corrigir a sua obra.

No poema VIII de O guardador de rebanhos, de Alberto Caiero, Jesus desce do céu “Tornado outra vez menino” e se desvincula da imagem do Cristo crucificado da Igreja Católica. Ele não parece ser totalmente humanizado, mas divinizado de outro modo: ele é “a criança tão humana que é divina”. Esse poema, como já vimos, inaugura uma nova fase das releituras do mito central do cristianismo dentro da Literatura Portuguesa em que Cristo é desdivinizado e redivinizado em outros termos que não o dos evangelhos bíblicos. De certo modo, esse Cristo que vem direto do céu sulfúrico de Junqueiro é o Jesus aparecerá em Saramago, um humanista por excelência.

Em A Última Tentação de Cristo, encontraremos um Jesus que sofre o dilema de querer assumir completamente a sua humanidade e ser obrigado a cumprir o seu papel como 
Filho de Deus. Nesse romance, podemos notar vários detalhes que reaparecerão de modo semelhante em O Evangelho Segundo Jesus Cristo. O Jesus de Kazantzakis não deseja cumprir o seu destino, tal como o Jesus de Saramago, embora acabe morrendo na cruz sem nenhuma resistência à vontade de Deus.

Na obra de Pär Largekvist vamos encontrar um Deus obscuro e insensível às necessidades humanas. Barrabás busca a sua vida toda entender a sua ligação com Jesus, que tomou o seu lugar na cruz sem nenhum sucesso, e acaba por ter o mesmo destino, sendo crucificado em Roma, ao lado de vários cristãos, entre os quais Pedro. Em Muerte de Ahasverus, o judeu errante, que havia sido condenado a vagar pelo mundo por uma maldição lançada por Jesus, só consegue se livrar dessa vida quando descobre que Deus é o verdadeiro responsável por seu sofrimento.

É possível perceber vários dos caracteres, com que nos deparamos em O Evangelho Segundo Jesus Cristo, espalhados por estes textos. Temos a figura do Deus truculento, intransigente e cruel em A Velhice do Padre Eterno, em A Última Tentação de Cristo, em Muerte de Ahasverus. O Jesus que deseja ser um homem e se alinha aos destinos humanos é semelhante ao de Kazantzakis ou ao desgraçado da novela de Pär Largerkvist.

Na segunda parte desse trabalho, o enfoque é dado à análise da personagem Jesus, de O Evangelho Segundo Jesus Cristo, de José Saramago com vistas nas obras referidas na primeira parte.

O Jesus de Saramago pode ser caracterizado pelo contraste em relação ao seu homônimo bíblico. Na Bíblia, a carreira terrena de Jesus desperta maior esforço de elaboração por parte dos evangelistas, uma vez que eles estão interessados em provar a natureza divina do herói de suas narrativas. Por outro lado, Saramago, bem como outros autores a que nos referimos acima, como, por exemplo, Kazantzakis, parece ter como objetivo mostrar um Jesus mais humano, que mesmo sendo filho de Deus, deseja viver como um homem.

Assim, o romance de Saramago apresenta não apenas uma outra versão do nascimento, em que Jesus é concebido como qualquer criança, através da relação sexual entre Maria e José, mas procura apresentar-nos uma infância em que Jesus não mostra nada de excepcional e um período intermediário da vida do herói, que é praticamente desconhecido nos evangelhos, e que assume uma importância fundamental no romance, pois é nessa fase que a personagem vai se transformar no indivíduo que será no desfecho da história. A história 
de Jesus é colocada sob a perspectiva do romance em que se torna relevante o processo de formação individual da personagem, a qual não se dá nenhuma importância no texto bíblico. Salientamos aqui que essa diferença pode repousar no fato de que os evangelhos bíblicos apresentam Jesus como um dado a priori, o messias prometido nas escrituras judaicas, possuidor de um caráter divino que dispensa a necessidade de um relato sobre sua vida que não esteja ligado ao seu papel messiânico já previsto pelos profetas. Por outro lado, o Jesus do romance se caracteriza como um indivíduo que vai tomando forma diante dos olhos do leitor.

Procuramos mostrar que o Cristo saramaguiano se insere dentro de um cânone literário que procura reler o mito inicial do Cristianismo a partir do século XIX. É possível notar, em O Evangelho Segundo Jesus Cristo, ecos dessas releituras, seja pela ênfase na humanidade da personagem Jesus, seja pela recuperação de outras personagens, como o Diabo e Maria de Magadala, as quais a tradição cristã relega a um segundo plano. É visível a semelhança entre o Deus de Saramago e o de Guerra Junqueiro, o de Kazantzakis ou o de Pär Lagerkvist. E o Jesus de Saramago e de algum modo semelhante ao de romancista grego, pois deseja, ao contrário da vontade de seu pai celestial viver como e morrer como um homem comum. 


\section{BIBLIOGRAFIA}

\section{Bibliografia ativa}

AUERBACH, Erich. Mimesis - a representação da realidade na literatura ocidental. São Paulo: Editora Perspectiva, 2004.

BAKHTIN, Mikhail. Questões de Literatura e Estética - A Teoria do Romance. São Paulo: Hucitec, 2002, $5^{\mathrm{a}}$. ed.

BERRINI, Beatriz. Para ler Saramago: o Romance. Lisboa: Editorial Caminho, 1998.

Bíblia de Jerusalém. São Paulo: Edições Paulinas, 5ª impressão, 1991.

BRANDÃO, Raul e PASCOAES, Teixeira. Jesus Cristo em Lisboa. Lisboa: Veja, 1984.

BUENO, Aparecida de Fátima. "Evangelhos finisseculares: Os Cristos de Eça de Queiroz e de José Saramago”, in: Revista da Biblioteca Mário de Andrade, v. 58, p. 201-206, 2000. Nas trilhas de Eça e Saramago: Representações de Cristo do século XX, in: Via Atlântica, nº. 6. São Paulo: Centro de Estudos Portugueses, 2003, pp. 55-64.

CASSIRER, Ernst. Linguagem e Mito (J. Guinsburg e M. Schnaiderman, trads.). São Paulo: Perspectiva, 1972.

“Mito e Religião” in: Ensaio sobre o Homem (Tomás Rosa Bueno, trad.). São Paulo: Martins Fontes, 1994, pp. 121-79.

CERDEIRA DA SILVA, Teresa Cristina. José Saramago entre a história e a ficção: uma saga de portugueses. Lisboa: Dom Quixote, 1989.

“A ficção reinventa a história”. In: Colóquio-Letras, n.

120. Lisboa, jun/1991, p. 174-178.

COSTA, Horácio. “José Saramago y la Tradición de la Novela Histórica en Portugal”, In: Mar Abierto. México: Fondo de Cultura Económica, 1998, pp. 163-74.

"La Novela Portuguesa en los años Ochentas: José Saramago", in: Mar Abierto. México: Fondo de Cultura Económica, 1998, pp. 141-62.

“Sobre la Posmodernidad en Portugal: Saramago 'Revisita' a Pessoa”, in:

Mar Abierto. México: Fondo de Cultura Económica, 1998, pp. 131-9. 
“The Fundamental Re-writing: Religious Texts and Contemporary Narrative. Gore Vidal's Live from Golgotha, Salman Rushidie's The Satanic Verses, José Saramago’s O Evangelho Segundo Jesus Cristo”, in: Poligrafías - Revista Portuguesa de Literatura Comparada, n. ${ }^{\circ}$ 1, 1996, pp. 189-98.

CROSSAN, John Dominic. Jesus histórico: a vida de um camponês judeu do Mediterrâneo (André Cardoso, trad.). Rio de Janeiro: Imago, 1994, 2ª ed.

DRURY, John. “Marcos”, in: Guia Literário da Bíblia (Raul Fiker, trad.). São Paulo: Unesp, 1997a, pp. 433-48.

“Lucas”, in: Guia Literário da Bíblia (Raul Fiker, trad.). São Paulo: Unesp, 1997b, pp. 449-71.

EÇA DE QUEIROZ, José Maria. A Relíquia. São Paulo: O Estado de São Paulo/ Klick Editora, 1997.

“Livros do Brasil”, 1999. “A morte de Jesus” in: Prosas Bárbaras. Lisboa: Edição “Suave Milagre” in: Contos. Porto: Lelo \& Irmãos, 1945.

ELIADE, Mircea. Mito e Realidade (Pola Civeli, trad.). São Paulo: Perspectiva, 2004.

O Sagrado e o Profano - A Essência das Religiões (Rogério Fernandes, trad.). São Paulo: Martins Fontes, 2001.

ELSON, Helen. “O Novo Testamento e a escrita greco-romana”, in: Guia Literário da Bíblia (Raul Fiker, trad.). São Paulo: Unesp, 1997, pp. 601-18.

FERRAZ, Salma. As faces de Deus na obra de um ateu. José Saramago. Juiz de Fora/Blumenau: Editora da UFJF/Edifurb, 2003.

O quinto evangelista: o (des)evangelho segundo José Saramago. Brasília: Editora Universidade de Brasília, 1998.

FEUERBACH, Ludwig. Essência do cristianismo (Adriana Serrão, trad.). Lisboa: Fundação Calouste Gulbenkian, 1994.

FLUSSER, David. Jesus (Margarida Goldsztajn, trad.). São Paulo: Perspectiva, 2002.

FOKKEMA, Douwe. “The Art of Rewriting the Gospel”, in: Colóquio-Letras, n. ${ }^{0}$ 151/152, janeiro/julho de 1999, pp. 395-402.

FRYE, Northrop. Anatomia da Crítica (Péricles Eugênio da Silva Ramos, trad.). São Paulo: Cultrix, 1973. 
O código dos códigos - A Bíblia e a Literatura (Flávio Aguiar, trad.). São

Paulo: Boitempo Editorial, 2004.

GABEL, John B., WHEELER, Charles B. A Bíblia como Literatura (Adail Ubirajara Sobral e Maria Stela Gonçalves, trad.). São Paulo: Edições Loyola, 1993.

HUTCHEON, Linda. Uma Teoria da Paródia (Tereza Louro Pérez, trad.). Lisboa: Edições 70, 1985.

JUNQUEIRO, Guerra. A Velhice do Padre Eterno. Porto: Lelo \& Irmãos, s/d.

KAZANTZAKIS, Nikos. A Última Tentação de Cristo. Rio de Janeiro: Rocco, 1988.

KERMODE, Frank. "Introdução ao Novo Testamento”, in: Guia Literário da Bíblia (Raul Fiker, trad.). São Paulo: Unesp, 1997a, p. 403-15.

“João”, in: Guia Literário da Bíblia (Raul Fiker, trad.). São Paulo:

Unesp, 1997c, p. 473-99.

“O cânone”, in: Guia Literário da Bíblia (Raul Fiker, trad.). São Paulo:

Unesp, 1997b, p. 416-31.

“Mateus”, in: Guia Literário da Bíblia (Raul Fiker, trad.). São Paulo:

Unesp, 1997d, p. 641-51.

KRISINSKI, Wladimir. "Le romanesque et le sacré - observations sur « L’Évangile Selon Jésus-Christ ». In: Colóquio-Letras, no 151/2. Lisboa: Gulbenkiam, janeiro/julho de 1999, p. 403-411.

LAGERKVIST, Pär. Barrabás (Guttorm Hanssen, trad.). Rio de Janeiro: Delta, 1966.

LINDER, Erik Hjalmar. "Vida e Obra de Pär Lagerkvist”, in: Barrabás. Rio de Janeiro: Editora Delta, 1966.

LOURENÇO, Eduardo. “De Pessoa a Junqueiro”. In: Fernando - Rei da nossa Baviera. Lisboa: Imprensa Nacional/Casa da Moeda, 1986, pp. 113-19.

LUKÁCS, Georg. A Teoria do Romance, (José Marcos Mariani de Macedo, trad.). São Paulo: 34, 2000.

MAURYA, Vibha. “Construction of Crowd in Saramago’s Texts”. In: Colóquio-Letras, nº. 151-2, 1999, pp. 267-78.

NERVAL, Gérard. "Le Christ aux Oliviers”, in : Poésies - Nerval et la Magie du Souvernir par Jean Richer. Paris : Union Générale d’Éditions, 1864. 
PERKINS, Pheme. “The Synoptic Gospels and Acts of the Apostles Telling the Christian Story” in: Biblical Interpretaion. Londres, Nova Iorque, Melbourne: Cambridge University Press, 1998.

PERRONE-MOISÉS, Leila. “O Evangelho Segundo Saramago”. In: José Saramago - uma homenagem. (BERRINI, Beatriz, org.). São Paulo: Educ, 1999, pp. 239-58.

PESSOA, Fernando. Obra poética. Rio de Janeiro: Nova Aguilar, 2005.

PAZ, Octávio. “Los Hijos del Limo”, in: Obras Completas, (em 12 vols.) vol 1. México: Fondo de Cultura Económica, 1993.

PILOSU, Mario. A mulher, a luxúria e a igreja na Idade Média. Lisboa: Editorial Estampa, 1995.

QUENTAL, Antero de. “As causas da decadência dos povos peninsulares”, in: Prosas SocioPolíticas. Lisboa: Casa da Moeda, 1982.

Sonetos. Lisboa: Livraria Sá da Costa, 1872.

REBELO, Luís de Sousa. “A consciência da história na ficção de José Saramago” in: Vértice, jan-fev/1993, nº. 52.

REIS, Jaime Batalha. “Introdução”, in: Eça de Queiroz, José Maria. Prosas Bárbaras. Lisboa: Edição “Livros do Brasil”, s/d, p. 7-46.

RENAN, Ernest. Vida de Jesus (Eduardo Augusto Salgado, trad.). Porto: Livraria Chardron, 1926.

O Anti-Cristo. (Campos Lima, trad.). Porto: Livraria Chardron, 1930.

SANT’ANNA, Jaime dos Reis. O Sagrado em Saramago. São Paulo: FFLCH/USP, 2005, Tese de Doutorado.

SARAMAGO, José. A jangada de pedra. São Letras, 2001a, 15ª reimpressão.

Ano da morte de Ricardo Paulo: Companhia Das Reis. São Paulo: Companhia das Letras, 2003, $10^{\mathrm{a}}$ reimpressão.

História do cerco de Lisboa. São Paulo: Companhia das Letras, 1989, $1^{\text {a }}$ reimpressão.

Levantado do chão. Rio de Janeiro: Bertrand Brasil, 2005a, 12a . ed. Memorial do convento. Rio de Janeiro: Bertrand Brasil, 2005b, 31ª ed. O Evangelho Segundo Jesus Cristo. São Paulo: Companhia das Letras, 2001b, 28 ${ }^{a}$ reimpressão. 
TRICCA, Maria Helena de Oliveira. Apócrifos: Os proscritos da Bíblia (4 vol.). São Paulo: Mercuryo, 1992.

VASCONCELOS, José Manuel de. "Prefácio”, in: Jesus Cristo em Lisboa. Lisboa: Vega, 1984.

VERMES, Geza. Jesus e o Mundo do Judaísmo (Adail Ubirajara Sobral e Maria Stela Gonçalves, trad.). São Paulo: Edições Loyola, 1996.

VIEIRA, Agripina Carriço. "Da História ao Indivíduo ou da Exceção ao Banal na Escrita de Saramago: do Evangelho Segundo Jesus Cristo a Todos os Nomes”. In: ColóquioLetras, nº 151/2. Lisboa: Gulbenkiam, janeiro/julho de 1999, pp. 379-93.

\section{Bibliografia passiva}

BAKHTIN, Mikhail. Problemas da Poética de Dostoievski (Paulo Bezerra, trad.). Rio de Janeiro: Forense Universitária, 1997, 2ª ed.

BOOTH, Wayne C. A Rhetoric of Irony. Chicago: University of Chicago Press, 1974. A Retórica da Ficção (Maria Teresa H. Guerreiro, trad.). Lisboa: Arcádia, 1980.

CANDIDO, Antonio. “A Personagem do Romance”. In: A Personagem de Ficção. São Paulo: Perspectiva, 2000, $10^{\mathrm{a}}$ ed.

COSTA, Horácio. José Saramago - O período formativo. Lisboa: Editorial Caminho, 1997.

DUNDES, Alan. Sacred Narrative - Readings in the Theory of Myth. Berkeley, Los Angeles, Londres: University of California Press, 1984, pp. 72-97.

ELIADE, Mircea. Tratado de História das Religiões (Fernando Tomaz e Natália Nunes, trads.). São Paulo: Martins Fontes, 1993.

FORSTER, E. M. Aspectos do Romance (Maria Helena Martins, trad.). Porto Alegre: Globo, 1974.

HUTCHEON, Linda. A poética do pós-modernismo (Ricardo Cruz, trad.). Rio de Janeiro: Imago, 1991.

KAUFMAN, Helena. “A Metaficção Historiográfica de José Saramago”, in: Colóquio-Letras, n. ${ }^{\circ} 120$, abril/junho de 1991, pp. 124-36. 
LUKÁCS, Georg. “Narrar o describir”, in: Problemas del Realismo (Carlos Gehard, trad.). México: Fondo de Cultura Econômica, 1996. The Historical Novel. Nebraska: Nebraska University, 1983.

MADRUGA, Conceição. A Paixão Segundo José Saramago. Porto: Campo das Letras, 1998. McHALE, Brian. Postmodernist Fiction. Londres, Nova Yorque: Routledge, 1991, c1987.

MOURA, Jean-Marc. L’Écriture et la vie selon José Saramago - sur « O ano da morte de Ricardo Reis ». In: Colóquio-Letras, n 151/2. Lisboa: Gulbenkiam, janeiro/julho de 1999, p. 281-90.

MUECKE, D. C. Ironia e o Irônico (Geraldo Gerson de Souza, trad.). São Paulo: Perspectiva, 1995.

NOGUEIRA, Carlos Roberto F. O Diabo no imaginário cristão. Bauru, SP: Edusc, 2000.

SEIXO, Maria Alzira. Lugares de Ficção e José Saramago - o essencial e outros ensaios. Lisboa: Imprensa Nacional - Casa da Moeda, 1999. 